\title{
Territorial Discrimination, Equal Protection, and Self-Determination
}

\section{Citation}

Gerald L. Neuman, Territorial Discrimination, Equal Protection, and Self-Determination, 135 U. Pa. L. Rev. 261 (1987).

\section{Published Version}

http://scholarship.law.upenn.edu/penn_law_review/vol135/iss2/6/

\section{Permanent link}

http://nrs.harvard.edu/urn-3:HUL.InstRepos:12965064

\section{Terms of Use}

This article was downloaded from Harvard University's DASH repository, and is made available under the terms and conditions applicable to Other Posted Material, as set forth at http:// nrs.harvard.edu/urn-3:HUL.InstRepos:dash.current.terms-of-use\#LAA

\section{Share Your Story}

The Harvard community has made this article openly available.

Please share how this access benefits you. Submit a story.

\section{Accessibility}




\title{
TERRITORIAL DISCRIMINATION, EQUAL PROTECTION, AND SELF-DETERMINATION
}

\author{
Gerald L. Neuman $\dagger$
}

TABLE of Contents

INTRODUCTION $\ldots \ldots \ldots \ldots \ldots \ldots \ldots \ldots \ldots$

I. A FrameWORK fOR Evaluating Geographical

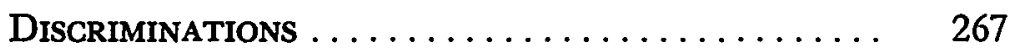

A. A Page of History.................. 267

B. A Volume of Logic .................. 276

1. Fundamental Rights and Equal Protection .. 276

2. The Need for Scrutiny of Geographical Discrimination: With Apologies for Some Jargon

3. General Position-Random Intrastate Variations ........................ 294

4. First Special Position-Independent Action of Political Subdivisions ................ 295

a. The Single Decisionmaker Fallacy..... 296

b. The Special Status of Political Subdivisions ....................... 301

c. Accommodating Self-Determination and Equal Protection ............... 309

5. Second Special Position-Interstate Variations 313

a. The Choice of Law Problem ......... 314

b. The Privileges and Immunities Perspective ...................... 319

c. Fundamental Rights Equal Protection and Choice of Law ............. 328

$\dagger$ Assistant Professor of Law, University of Pennsylvania Law School. logic.

This article is dedicated to Archibald Cox, who taught me to prefer reason to

Earlier versions of this article were presented to faculty groups at Harvard Law School, The University of Chicago Law School, and the University of Pennsylvania Law School in February and October of 1983. I thank all those present for their incisive comments. I am especially grateful for comments and advice from my colleagues Regina Austin, Stephen Burbank, Michael Fitts, Seth Kreimer, Harold Maier, Curtis Reitz, Clyde Summers, Akhil Amar, Harold Koh, and Ed Baker, whose patience was inexhaustible. I also thank Mrs. Margaret Ulrich for her extraordinary skill and dedication, which made control of this unwieldy text possible. 
d. Interstate Variations Not Resulting from Choice of Law ..................

6. Third Special Position-Special Laws and Local Option Laws, with a Digression on Circuit Conflicts ....................

7. Fourth Special Position-Federal Discrimination Along State Boundary Lines..........

a. Types of Federal Discrimination ...... 344

b. Virtues of Federal Incorporation...... 348

c. Complication: The District of Columbia

II. The Framework Applied $\ldots \ldots \ldots \ldots \ldots \ldots \ldots$

A. United States v. Cohen . . . . . . . . . . . . . 359

1. Background on Commitment of Insanity Ac-

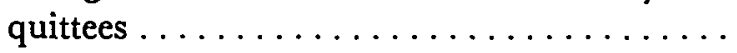

2. Analyzing Cohen's Challenge ......... 366

B. The School Finance Cases ............... 372

1. Easy Cases ................... 374

2. Harder Cases ................... 375

3. The Other Extreme-District Power Equali-

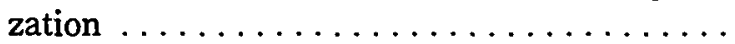

\section{INTRODUCTION}

"[G]eography is fate." Dred Scott could testify to the truth of this observation, ${ }^{2}$ as could the children of the impoverished school districts that lost in San Antonio Independent School District v. Rodriguez. ${ }^{3}$ Throughout our history, arbitrary geographical boundary lines have made tremendous differences to the lives of innocent people. In other contexts, equal protection has served as a defense against arbitrary denials of liberty. How then does equal protection mitigate the influence that political geography exerts over our destinies?

Geographical classifications are very common in our legal system. Municipal ordinances, zoning laws, state "special" legislation and local option laws, federal statutes that apply differently in different states, residence requirements, choice of law rules, and circuit conflicts are

1 Grossfeld, Geography and Law, 82 Mich. L. Rev. 1510, 1512 (1984).

2 See Scott v. Sandford, 60 U.S. (19 How.) 393 (1857). Scott lost in his claim that after returning to a slave state from a free territory he could no longer be held in bondage.

3411 U.S. 1 (1973). The children lost in their claim that Texas owed them an education equal to that provided to children in wealthier districts. 
only some of the techniques by which our rights are made to vary depending on where we are or where we live. We frequently take the differences created by these techniques for granted, but when these techniques are applied to legal regulation of constitutionally protected activities, we should think more carefully before accepting the differences that result.

Some legal discriminations turn expressly on place of residence; ${ }^{4}$ such discriminations have sparked much scholarly comment when they disfavor out-of-staters. ${ }^{5}$ Other discriminations are defined by geographical factors different from residence and affect residence classes at most indirectly. These discriminations, which I will call "territorial," will be the major focus of this article.

Territorial discriminations can arise in many ways. Take, for example, a simple problem of libel. The Supreme Court has held that the states may impose civil liability for negligent defamation of a private figure, though they are not required to do so. $^{6}$ Liability for unintended falsehoods places serious burdens on first amendment rights. Suppose that the State of New York enacted a statute making the standard of liability for libel negligence if the libel were communicated within New York City, but actual knowledge of falsity in the rest of the state. Or that the courts of New York imposed the negligence standard for libels communicated within the state, but other rules for libels communicated elsewhere. Or that the City of New York adopted an ordinance creating liability for negligent defamation, even though the state law standard was recklessness. Or that Congress enacted a libel statute applying only within the District of Columbia, or only within the states of the old Confederacy. In each case, a territorial discrimination has been created, setting different standards of conduct for the exercise of communicative activity in different places. Should any of these be regarded as offensive to the principle of equal protection?

Courts have often regarded territorial discriminations as inherently

- For important earlier analyses of residence classifications reaching conclusions different from those I will describe, see Harvith, The Constitutionality of Residence Tests for General and Categorical Assistance Programs, 54 CALIF. L. REv. 567 (1966); Horowitz \& Neitring, Equal Protection Aspects of Inequalities in Public Education and Public Assistance Programs from Place to Place Within a State, 15 UCLA L. REV. 787 (1968).

- See, e.g., Antieau, Paul's Perverted Privileges or the True Meaning of the Privileges and Immunities Clause of Article Four, 9 WM. \& MARY L. REV. 1 (1967); Ely, Choice of Law and the State's Interest in Protecting Its Own, 23 WM. \& MARY L. REv. 173 (1981); Simson, Discrimination Against Nonresidents and the Privileges and Immunities Clause of Article IV, 128 U. PA. L. REv. 379 (1979); Varat, State "Citizenship" and Interstate Equality, 48 U. CHI. L. REv. 487 (1981).

- See Dun \& Bradstreet, Inc. v. Greenmoss Builders, 105 S. Ct. 2939, 2944-46 (1985); Gertz v. Robert Welch, Inc., 418 U.S. 323, 347-48 (1974). 
innocuous. For example, when the public school system of Prince Edward County, Virginia was shut down to avoid the prospect of desegregation, the United States Supreme Court observed:

[T]here is no rule that counties, as counties, must be treated alike; the Equal Protection Clause relates to equal protection of the laws "between persons as such rather than between areas."...

. . . A State, of course, has a wide discretion in deciding whether laws shall operate statewide or shall operate only in certain counties, the legislature "having in mind the needs and desires of each."

In fact, though the modern Supreme Court has invalidated territorial discriminations on numerous occasions, ${ }^{8}$ it has never openly confronted the question of when territorial discriminations can raise equal protection problems, and its opinions are spotted with citations to older cases holding that they never can. The absence of a self-conscious approach to these problems becomes a significant handicap when courts confront unfamiliar configurations of territorial discrimination. For example, a broad inquiry into the question of territorial discrimination illuminates some traditional conundrums of conflict of laws ${ }^{9}$ and even sheds an unusual light on the Supreme Court's exercise of its certiorari jurisdiction. ${ }^{10}$ Similarly, it provides guidance in the confused area of claims of congressional discrimination against the District of Columbia. ${ }^{11}$

7 Griffin v. County School Bd., 377 U.S. 218, 230-31 (1964) (quoting Salsburg v. Maryland, 346 U.S. 545, 551-52 (1954)). It is true that the Court went on to hold that abolishing public schools in order to avoid desegregation was action for an illegal purpose and therefore unconstitutional, see id. at 231-32, but it is interesting that the Court assumed so easily that Virginia could have abolished public education in a single county if its reason had not been unlawful.

${ }_{8}$ Less than a month after its decision in Griffin, the Court struck down Alabama's allocation of legislative seats among its counties, insisting that "[t]he Equal Protection Clause demands no less than substantially equal state legislative representation for all citizens, of all places as well as all races." Reynolds v. Sims, 377 U.S. 533, 568 (1964). One might ask whether this holding made equal protection operate "between areas" rather than "between persons as such."

- See infra notes $224-98$ and accompanying text.

10 See infra notes $340-48$ and accompanying text.

11 The D.C. Circuit has struggled over the years with claims that congressional "discrimination" against the District of Columbia violates equal protection and has been unable to achieve consensus on whether such discrimination can ever exist. Compare United States v. Cohen, 733 F.2d 128 (D.C. Cir. 1984) and United States v. Greene, 489 F.2d 1145 (D.C. Cir. 1973), cert. denied, 419 U.S. 977 (1974) with United States v. Thompson, 452 F.2d 1333 (D.C. Cir. 1971). In a later section, I will argue that, although the problem is complex, there are situations where equal protection principles may condemn congressional discrimination against the District. See infra notes $385-418$ and accompanying text. 
In this Article, I would like to examine the law and theory of equal protection as it relates to discriminations in the scope of fundamental rights on the basis of geographical factors. I will argue that, contrary to some old cases and some recurring dicta, territorial discriminations should not be wholly exempt from equal protection analysis. In particular, territorial discriminations impinging upon fundamental rights should presumptively be subject to the same heightened scrutiny as any other fundamental rights discriminations. Certain forms of territorial discrimination that would not withstand heightened scrutiny, however, are intimately linked to the operation of self-government in our federal system. As courts have long observed, toleration of these forms of territorial discrimination accommodates processes of political self-determination that our society values highly. The familiar tension between liberty and equality manifests itself here in the conflicting claims of local self-determination and territorial nondiscrimination. I will argue that the tension should be resolved in this context by recognizing that forms of territorial discrimination resulting from local selfdetermination are truly exceptional. For reasons that are partly theoretical and partly historical, normal equal protection analysis should be modified in these exceptional cases so as to excuse the resulting discrimination from heightened scrutiny. ${ }^{12}$ This modification would preserve our traditions of local self-determination while maintaining a proper vigilance toward other forms of territorial discrimination.

Part I of this Article sets out a suggested framework for evaluating geographical discriminations under the equal protection clause. Part I(A) poses the problem by describing the curious history of the Supreme Court's attitudes toward territorial discrimination over the past century. Part $I(B)(1)$ then sets out the needed foundation regarding the much criticized doctrine of fundamental rights equal protection. With this foundation in place, Part $I(B)(2)$ explains the difference between residence discrimination and location discrimination. This part concludes that, in the context of fundamental rights, both raise legitimate equal protection concerns where they commonly have been overlooked.

The framework then begins. Part I(B)(3) states a general proposi-

12 Among the libel examples discussed above, I would encourage close scrutiny of the discrimination by the New York state legislature against New York City and of the discrimination by Congress against the states of the old Confederacy. I would discourage close scrutiny of the discrimination resulting from the New York City ordinance and of the statute applying only in the District of Columbia. Assuming that the discrimination practiced by the New York courts resulted from the application to each case of the law of the jurisdiction where the libel was communicated, I would discourage close scrutiny; otherwise I would be in favor of it. The reasons for these conclusions will become clear later in this Article. 
tion-geographical discriminations affecting fundamental rights are subject to heightened scrutiny - while reserving judgment on geographical discriminations whose contours coincide with political boundary lines. Parts $I(B)(4)-I(B)(7)$ address four typical categories of geographical discrimination along political boundary lines and the specific contexts within each category where fundamental rights equal protection questions may arise. ${ }^{13}$ In some of these specific categories, I will conclude that the discriminations should be subjected to heightened scrutiny, which they will normally fail. In other categories, however, I will argue that the normal equal protection analysis should be modified to excuse the discrimination from heightened scrutiny in the name of political self-determination.

Finally, in Part II, I apply the framework set out above to two vexing examples-a claim of discrimination by the federal government against the District of Columbia and the claims of intrastate discrimination on which school finance litigation is founded. In both cases I conclude that focusing on the problem of local self-determination is essential to achieving a persuasive resolution of the claims.

1s A more detailed description of the framework may be in order. Part $I(B)(4)$ considers the discriminations resulting when two cities within the same state adopt different measures; I argue that the universal practice of utterly ignoring such discriminations requires more explanation than is generally thought. After exploring the forms of discriminatory state action cognizable under the equal protection clause, I conclude that contrasting municipal approaches to fundamental rights are a very special category of state action that is excused from heightened scrutiny in order to further the constitutional value of local self-determination. This conclusion is key to the rest of the Article; thereafter I will argue in other contexts that certain kinds of geographical discrimination similarly serve to effectuate local self-determination and should similarly be excused from heightened scrutiny.

In ,Part $\mathrm{I}(\mathrm{B})(5)$ I consider state governmental discriminations based upon state boundary lines, with particular attention to problems of discrimination in choice of law. After a necessary plunge into the lore of the privileges and immunities clause, I articulate a method for determining which interstate discriminations operate to preserve selfdetermination and should therefore be excused from heightened scrutiny, while leaving the others to the usual fundamental rights equal protection analysis.

In Part $I(B)(6)$ I consider state governmental discriminations based upon political boundary lines within the state and try to identify the forms of intrastate discrimination that further local self-determination and should therefore be excused from heightened scrutiny.

In Part $I(B)(7)$ I address geographical discriminations by the federal government. I conclude that federal geographical discriminations should normally be subject to heightened scrutiny, but that certain forms of federal incorporation of state law preserve the state's opportunities for self-determination and should therefore be excused from heightened scrutiny. 


\section{A Framework for Evaluating Geographical DISCRIMINATIONS}

Legal distinctions based on geography may be divided initially into two categories. ${ }^{14}$ One category, which I will call "explicit residence discriminations," consists of distinctions that turn expressly on the place of residence of the affected groups. The other category, which I will call "territorial discriminations," consists of distinctions based on geographical factors different from residence, such as the identity of the land forming the location of the regulated conduct, the situs of things, or the seat of institutions, and affect residence classes at most indirectly. Because they have evoked less study, I will make this second category, the "territorial discriminations," the major focus of attention. I should state at the outset, however, that this Article will not be advocating that significant emphasis should be placed on the differences between residence and territorial discriminations for the purposes of equal protection analysis.

\section{A. A Page of History}

Two contradictory approaches to territorial discriminations have competed for judicial attention over the years. The Supreme Court disposed of many claims of discrimination by flatly denying that territorial classifications are subject to equal protection scrutiny at all. ${ }^{15}$ In other cases, that same Court treated territorial classifications as susceptible to the usual rationality review but upheld them on the merits ${ }^{16}$ or applied more stringent scrutiny because fundamental rights were at stake. ${ }^{17} \mathrm{Al}$ though this second approach has dominated the Court's analysis since early in this century, it has not yet fully silenced its rival.

The Court first analyzed the problem of territorial discriminations in 1880 , in the case of Missouri v. Lewis. ${ }^{18}$ Frank Bowman was an

14 I believe it was the American sociologist Robert Benchley who observed that the world is divided into two categories of people, those who divide everything into two categories and those who don't.

18 See, e.g., Hayes v. Missouri, 120 U.S. 68 (1887); Barbier v. Connolly, 113 U.S. 27 (1885). Other cases taking this approach are cited in notes 29, 30, and 41 infra.

${ }^{16}$ See, e.g., Reinman v. City of Little Rock, 237 U.S. 171 (1915). Other cases taking this approach are cited in notes 38,42 , and 56 infra.

${ }_{17}$ See, e.g., Reynolds v. Sims, 377 U.S. 533 (1964). Other cases taking this approach are cited in notes 62-64 infra.

is 101 U.S. 22 (1880). The Court had previously confronted a city ordinance applying only to a single named railroad company and upheld it against equal protection attack on the grounds that the company was the only one operating on a particular street and that local conditions on that street might require special measures. See Railroad Co. v. Richmond, 96 U.S. 521, 529 (1878). 
attorney disbarred by the Circuit Court of St. Louis County. Missouri law channeled most appeals from St. Louis and three other counties to the St. Louis Gourt of Appeals instead of the state supreme court. Bowman complained that attorneys disbarred in other counties could appeal directly to the state Supreme Court, while he was deprived of "the superiority of [its] wisdom and power."19

The Lewis Court denied that the equal protection clause was even relevant to Bowman's situation, reasoning that the fourteenth amendment was never intended to limit the flexibility of the states in parceling out authority to political subdivisions. ${ }^{20}$ In fact, the Court went so far as to insist that "there is nothing in the Constitution to prevent any State from adopting any system of laws or judicature it sees fit for all or any part of its territory." 21 In the Court's opinion, the equal protection clause meant only that "no person or class of persons shall be denied the same protection of the laws which is enjoyed by other persons or other classes in the same place and under like circumstances."22 Since laws can vary from state to state, the Court saw "no solid reason"2s to restrict such variations within a state. Thus, a state conceivably could adopt the common law for one portion of its territory and the civil law for another portion. ${ }^{24}$

The Court did recognize one possible situation in which a territorial distinction might offend the equal protection clause: if the classification "might be intended as, or might have the effect of, a discrimination against a particular race or class, where such race or class should happen to be the principal occupants of the disfavored district."28 Bowman himself could make no such claim.

Several strands can be discerned in the Lewis opinion. First, the Court observed that convenience, if not necessity, required that the state be permitted to regulate local affairs by creating political subdivisions. Thus, some territorial distinctions in government structure are clearly justified; this is all the case itself involved. Second, differing local condi-

19 Lewis, 101 U.S. at 27.

20 See id. at 30 .

21 Id. at 31 .

22 Id. (emphasis added).

23 Id.

24 For example, a state that had received additional territory newly acquired from Mexico would have strong cause to do so, but a state like New York could follow the same course if it saw fit. See id. at 31-32.

${ }^{28} I d$. at 32 . In other words, a putatively territorial classification might turn out to be a cover for racial discrimination. Cf. Gomillion v. Lightfoot, 364 U.S. 339 (1960) (altering boundaries of City of Tuskegee from a square to an "uncouth twenty-eight sided figure" that excluded almost every black voter would violate fifteenth amendment); see also infra notes 35-37 and accompanying text (discussing state discrimination against out-of-staters). 
tions might sometimes call for geographical variations in substantive law. These variations also would not violate equal protection. Going beyond these examples, the Court announced its broader principle-all territorial distinctions are automatically lawful, unless they are rooted in discrimination against some race or class not geographically defined.

The breadth of the Court's language is understandable in historical context. Equal protection doctrine was then in its first decade. Only seven years had elapsed since the Court, in its first confrontation with the new equal protection clause, had intimated that the fourteenth amendment forbade only racial discrimination. ${ }^{26}$ The Court had since shown a willingness to expand the clause's application and was working on a doctrine that would permit nonracial legislative classifications, so long as everyone coming within the terms of the statute fared equally. ${ }^{27}$ Later, as the vacuity of this formulation became evident, the Court would find it necessary to examine the "reasonableness" of classifications. ${ }^{28}$ This had not yet happened in 1880 .

For several decades, the precedential authority of Lewis impeded re-analysis of territorial classifications under the new reasonableness test. The Court upheld local variations in governmental structure and procedure $^{2 \theta}$ and legislation limiting business activities in certain geographical areas $^{30}$ without examining their rationality. Some of the

${ }^{36}$ See Slaughter-House Cases, 83 U.S. (16 Wall.) 36 (1873).

27 See, e.g., Kentucky R.R. Tax Cases, 115 U.S. 321, 337 (1885) (application to all railroad property); Barbier v. Connolly, 113 U.S. 27, 31-32 (1885) (application to all public laundries in certain portions of city); see generally Oregon v. Mitchell, 400 U.S. 112, 241 (1970) (Brennan, J., concurring in part and dissenting in part) (discussing development of equal protection doctrine); Tussman \& tenBroek, The Equal Protection of the Laws, 37 CALIF. L. REv. 341, 342, 345 \& n.12 (1949) (same).

28 See, e.g., Gulf, C. \& S.F. Ry. v. Ellis, 165 U.S. 150, 155 (1897).

29 See, e.g., Gardner v. Michigan, 199 U.S. 325, 333 (1905) (quoting Lewis) (allowing different process for compiling jury lists in one county); Mallett v. North Carolina, 181 U.S. 589, 598 (1901) (quoting Lewis) (finding no equal protection violation in law allowing prosecution appeals only from eastern district of state); Mason v. Missouri, 179 U.S. 328, 335 (1900) (not citing Lewis) (allowing voter registration system for St. Louis different from that in rest of state); Chappell Chemical \& Fertilizer Co. v. Sulphur Mines Co., 172 U.S. 474, 475 (1899) (citing Lewis) (finding no equal protection violation in denial of jury trial in one city); Williams v. Eggleston, 170 U.S. 304, 309-10 (1898) (not citing Lewis) (finding no equal protection violation in the consolidation of five towns leading to different control in respect to highways); Hayes v. Missouri, 120 U.S. 68, 72 (1887) (citing Lewis) (finding no equal protection violation in variation in number of peremptory challenges).

so See, e.g., Ohio ex rel. Lloyd v. Dollison, 194 U.S. 445, $448-49$ (1904); Rippey v. Texas, 193 U.S. 504, 509 (1904) (both upholding local option liquor laws against equal protection challenge) (The usual cases were cited by the parties in Rippey, but Justice Holmes did not mention equal protection in his opinion.); L'Hote v. City of New Orleans, 177 U.S. 587, 597 (1900) (upholding creation of red light district) ("I]nquiry as to the reasonableness or propriety of the limits is a matter for legislative consideration, and cannot become the basis of judicial action."); Budd v. New York, 
opinions hinted at reasons why the variations might be appropriate, ${ }^{31}$ but none suggested that a territorial distinction could be invalidated if unreasonable. Lewis and its corollary Hayes v. Missouri ${ }^{32}$ were frequently quoted in general discussions of equal protection, further perpetuating in dictum the proposition that the Constitution forbade only unequal treatment of two persons "in the same place."33

In contrast, the Court had no difficulty recognizing explicit residence discriminations as classifications calling for equal protection scrutiny. ${ }^{34}$ Much of the caseload involved state discriminations against nonresident individuals and foreign corporations. ${ }^{36}$ For many years the

143 U.S. 517, 548 (1892) (upholding elevator rate regulation only in large cities); Soon Hing v. Crowley, 113 U.S. 703 (1885); Barbier v. Connolly, 113 U.S. 27, 30-31 (1885) (both upholding regulation of laundries within defined territorial limits); $c f$. Cox v. Texas, 202 U.S. 446, 450 (1906) (stating that a tax discriminating between sellers of domestic and out-of-state wine did not involve a "classification").

s1 See, e.g., Hayes, 120 U.S. at 72 (stating that allowing more peremptory challenges in jury selection in large cities may be necessary to secure an impartial jury); Barbier, 113 U.S. at 30 (stating that restricting laundries from certain areas may reduce fire and drainage problems).

32120 U.S. 68 (1887).

ss See, e.g., Connolly v. Union Sewer Pipe Co., 184 U.S. 540, 559 (1902); Brown v. New Jersey, 175 U.S. 172, 175-77 (1899); Holden v. Hardy, 169 U.S. 366, 387-88 (1898). In fact the currency of the dictum continued long after the practice had changed. See, e.g., Truax v. Corrigan, 257 U.S. 312, 333, 336 (1921).

s4 See, e.g., Board of Educ. v. Illinois, 203 U.S. 553, 563 (1906) (upholding statute exempting only instate charities from inheritance tax); Field v. Barber Asphalt Paving Co., 194 U.S. 618, 622 (1904) (upholding statute allowing only resident property owners to protest improvement scheme); Kidd v. Alabama, 188 U.S. 730, 732 (1903) (upholding right of state to tax stock of foreign incorporated railroads while not taxing. stock of domestic railroads or foreign railroads doing business in state); Central Loan \& Trust Co. v. Campbell Comm'n Co., 173 U.S. 84, 97-99 (1899) (upholding statute establishing different procedures for attaching property of residents and nonresidents); see also Pope v. Williams, 193 U.S. 621, 634 (1904) (dictum) (suggesting the impermissibility of distinguishing between residents based on state of former residence); Philadelphia Fire Ass'n v. New York, 119 U.S. 110, 129 (1866) (Harlan, J., dissenting) (arguing the impermissibility of imposing different tax rates on foreign corporations). For a different kind of discrimination favoring "residents," see Watson v. Maryland, 218 U.S. 173 (1910).

so Inhospitable treatment of citizens of sister states always implicated the privileges and immunities clause of article IV, but the contours of that clause were eccentric, see, e.g., Pope, 193 U.S. at 632 (right to vote not a privilege or immunity); McCready v. Virginia, 94 U.S. 391, 395 (1877) (right to plant oysters in tidal river not a privilege or immunity); Conner v. Elliott, 59 U.S. (18 How.) 591, 593 (1856) (right to community property not a privilege or immunity), and it did not protect corporations. See Paul v. Virginia, 75 U.S. (8 Wall.) 168, 178-82 (1869). For a while, the Court also flirted with the idea that only citizenship discriminations, not residence discriminations, violated the clause, so that a state willing to sacrifice its own nonresident citizens could effectively discriminate against out-of-staters. See La Tourette v. McMaster, 248 U.S. 465,470 (1919). This absurd formalism has since been abandoned. See Austin v. New Hampshire, 420 U.S. 656,662 n.8 (1975).

Discrimination against nonresidents could have violated the dormant commerce clause, but the scope of interstate commerce was also technical and complex. See, e.g., 
Court had trouble applying the equal protection clause in the case of foreign corporations. The Court was distracted by the theory that, until a foreign corporation had complied with all the prerequisites a state imposed from time to time as conditions on doing business in the state, the corporation was not within the jurisdiction of the state for purposes of the clause. ${ }^{38}$ This approach was slowly discarded over the first decades of the century, and by 1910 the Court had actually held a discrimination against foreign corporations to be a denial of equal protection. $^{\mathbf{3 7}}$

Also around 1910, the Court quietly extended its normal equal protection method to territorial distinctions in general. The Court always upheld them, but it unquestioningly subjected them to scrutiny for arbitrariness under the equal protection clause. ${ }^{38}$ The new approach was well articulated in Reinman v. City of Little Rock. ${ }^{39}$ In the Court's words:

[S]o long as the regulation in question is not shown to be clearly unreasonable and arbitrary, and operates uniformly upon all persons similarly situated in the particular district, the district itself not appearing to have been arbitrarily selected, it cannot be judicially declared that there is a deprivation of property without due process of law, or a denial of

United States v. E.C. Knight Co., 156 U.S. 1, 12 (1895) (manufacturing not commerce); Paul, 75 U.S. at 183 (insurance not commerce).

${ }^{\text {s6 }}$ See, e.g., Blake v. McClung, 172 U.S. 239, 253 (1898); Philadelphia Fire Ass'n, 119 U.S. at 119. See generally Western \& So. Life Ins. Co. v. State Bd., 451 U.S. 648, 657-65 (1981) (tracing the decline of this view).

${ }^{37}$ See Southern Ry. v. Greene, 216 U.S. 400 (1910). Even before Southern Ry., the Court occasionally scrutinized-but upheld-discriminations between interstate and intrastate businesses. See, e.g., Cook v. Marshall County, 196 U.S. 261 (1905) (finding that discrimination favoring interstate wholesalers satisfied weak standard for tax classifications); Williams v. Fears, 179 U.S. 270 (1900) (taxing business of hiring workers for employment out of state, but not instate, not unreasonable).

Equal protection scrutiny of explicit residence classifications has frequently led to invalidation in the years since Southern Ry. See, e.g., Metropolitan Life Ins. Co. v. Ward, 105 S. Ct. 1676 (1985); Evans v. Cornman, 398 U.S. 419 (1970); Moore v. Ogilvie, 394 U.S. 814 (1969); WHYY, Inc. v. Borough of Glassboro, 393 U.S. 117 (1968); Wheeling Steel Corp. v. Glander, 337 U.S. 562 (1949); Power Mfg. Co. v. Saunders, 274 U.S. 490 (1927).

ss See Toyota v. Hawaii, 226 U.S. 184, 191 (1912) (finding "reasonable basis" for higher auctioneer's license fee in Honolulu); City of Chicago v. Sturges, 222 U.S. 313, 324 (1911) (finding discrimination between cities and other municipalities in tort liability "not so unreasonable and extravagant as to be a mere arbitrary mandate"); Welch v. Swasey, 214 U.S. 91, 105, 108 (1909) (equal protection piggybacked on due process in challenge to geographically limited restriction on building height). Where land was classified by its use rather than by its location, the Court had applied the reasonableness test as early as Clark v. Kansas City, 176 U.S. 114, 120-21 (1900) (upholding statute authorizing municipal annexation of nonagricultural land only).

so 237 U.S. 171 (1915). 
the equal protection of the laws ....40

Although there were a few apparent reversions to the per se rule of Lewis, particularly in cases involving territorial discrimination in civil or criminal procedure, ${ }^{41}$ rationality review had become dominant. ${ }^{42}$

In practice, however, the choice of approach did not yet matter, because the Court was always willing to hypothesize a local variation in conditions sufficient to render any territorial classification rational. The only distinctions formally recognized as subject to more stringent equal protection scrutiny during this period were those invidiously motivated against a racial or national group. ${ }^{43}$ But the Court's 1942 decision in Skinner v. Oklahoma ex rel Williamson ${ }^{44}$ created greater potential for divergence between the categorical and case-by-case approaches to territorial discriminations. In Skinner, Justice Douglas openly launched the fundamental rights branch of equal protection. ${ }^{45}$ As subsequently elaborated, "strict scrutiny" could be triggered, not only by classifications invidious in themselves, but also by employment of virtually any classification to infringe upon the exercise of a funda-

40 Id. at 177 (emphasis added) (upholding prohibition of livery stables in certain section of city).

${ }^{41}$ See Young v. Masci, 289 U.S. 253, 260-61 (1933) (dismissing out of hand equal protection claim based on location of auto accident); Ocampo v. United States, 234 U.S. 91, 98-99 (1914) (applying Lewis to statutory right to equal protection in the Philippines, and upholding variation in criminal procedure between Manila and rest of the Islands); $c f$. Ohio ex rel. Bryant v. Akron Metro. Park Dist., 281 U.S. 74, 81 (1930) (citing Lewis) (finding that even if statute's practical effect was to prevent state supreme court from resolving conflicts between county courts of appeal, no equal protection question would arise); Joslin Mfg. Co. v. City of Providence, 262 U.S. 668, 676 (1923) (upholding a statute compensating displaced millowners for expenses of relocating within New England, but not elsewhere).

12 See Radice v. New York, 264 U.S. 292, 296 (1924) (statute regulating working hours of women in large cities); Fort Smith Light \& Traction Co. v. Board of Improvement, 274 U.S. 387, 391 (1927) (statute territorially defined to apply to single street railway company); Packard v. Banton, 264 U.S. 140, 143-44 (1924) (statute regulating taxis in large cities); Thomas Cusack Co. v. City of Chicago, 242 U.S. 526, 529-30 (1917) (limit on billboards in residential sections of city); Northwestern Laundry v. City of Des Moines, 239 U.S. 486, 492, 495 (1916) (statute empowering large cities to regulate smoke, implemented by ordinance applying only in certain portions of city); Haracheck v. Sebastian, 239 U.S. 394, 411-13 (1915) (prohibition of brickyards in certain district of city).

Some cases are simply too opaque to interpret. See Walls v. Midland Carbon Co., 254 U.S. $300,315,324$ (1920) (permitting regulation of gas use within 10 miles of towns); Stewart v. City of Kansas Gity, 239 U.S. 14 (1915) (upholding variations in finance system disadvantageous to large cities).

ts See, e.g., Missouri ex rel. Gaines v. Canada, 305 U.S. 337 (1938) (finding equal protection violation in state's provision of legal education to whites but not to blacks).

11316 U.S. 535 (1942).

t5 $I d$. at 541 ("[S]trict scrutiny of the classification which a State makes in a sterilization law is essential."). 
mental right. ${ }^{48}$

The effect of this change was demonstrated shortly thereafter by the willingness of Justices Douglas, Black, and Murphy to strike down territorial classifications infringing electoral rights in Colegrove $v$. Green. ${ }^{47}$ Colegrove was a malapportionment case of a now familiar kind. The majority refused to take jurisdiction and expressed no views on the merits. ${ }^{48}$ Justice Black, in contrast, found "a wholly indefensible discrimination against appellants and all other voters in heavily populated districts, ... exactly the kind that the equal protection clause was intended to prohibit." 49 Yet the discrimination resulted not from an explicit classification regarding residence, but merely from the drawing of boundaries for congressional election districts. No Justice alluded to the possibility that discriminations based on geographical location were immune from equal protection scrutiny.

The victory of the rational basis test over the per se rule in the modern period is exemplified by Salsburg $v$. Maryland. ${ }^{50}$ There, the Court unequivocally applied rational basis scrutiny to territorial variations in the excludability of illegally seized evidence within a state. ${ }^{51}$ Even in the field of court procedures, where the influence of Lewis had been greatest, ${ }^{\mathrm{s2}}$ the territorial discrimination was entitled only to a presumption of reasonableness. ${ }^{\text {s3 }}$ At the same time, however, the Court quoted the usual Lewis dicta, and floated a popular new epigram: "The

40 This seems to follow from Skinner itself. Some have tried to characterize the particular discrimination condemned in Skinner, between larcenists (who would be sterilized) and embezzlers (who would not) as wealth-based or class-based. See L. Tribe, AMERICan Constrtutional Law 1010-11 (1978); Karst, Invidious Discrimination: Justice Douglas and the Return of the "Natural-Law-Due-Process Formula," 16 UCLA L. REv. 716, 734-35 (1969). But the opinions give no hint of this, and this feature of the case is better regarded as coincidental. See J. Ely, Democracy \& DisTRUST 245 n.38 (1980).

17328 U.S. 549, 569 (1946) (Black, J., dissenting). Their position prevailed eighteen years later in Reynolds v. Sims, 377 U.S. 533 (1964).

The same Justices who dissented in Colegrove also dissented in MacDougall v. Green, 335 U.S. 281 (1948), which involved an explicit residence discrimination in the distribution of signatures necessary for a nominating petition. Their position in MacDougall prevailed in Moore v. Ogilvie, 394 U.S. 814 (1969).

48 See 328 U.S. at 556. (Frankfurter, Reed, and Burton, JJ., finding the case nonjusticiable); id. at 566 (Rutledge, J., declining to exercise jurisdiction).

19 Id. at 569.

so 346 U.S. 545 (1954).

s1 See id. at 550-51, 553.

62 See, e.g., Gardner v. Michigan, 199 U.S. 325, 333 (1905) (quoting Lewis) (allowing different process for compiling jury lists in one county); Mallett v. North Carolina, 181 U.S. 589, 598 (1901) (quoting Lewis) (no equal protection violation in law allowing prosecution appeals only from eastern district of state).

63 See Salsburg, 346 U.S. at 553 \& n.9. For a similar reversal of attitude, see Holt Civic Club v. City of Tuscaloosa, 439 U.S. 60, 70-71 (1978) (applying the rational basis test to a state's allocation of power among its political subdivisions). 
Equal Protection Clause relates to equality between persons as such rather than between areas." between this language and its application of a reasonableness test-it seemingly viewed Lewis as holding only that territorial variations are not unreasonable per se.

A trace of ambiguity has continued to plague the Supreme Court's opinions, ${ }^{\text {s5 }}$ but in the great majority of cases the Court has applied the rational basis test to state and federal legislation. ${ }^{58}$ The lower federal courts have displayed some confusion, ${ }^{57}$ but most frequently do scrutinize territorial classifications. ${ }^{58}$ In fact, a few courts have invalidated some territorial classifications as wholly irrational. ${ }^{59}$ Justices White, Douglas, and Brennan were willing to do so in San Antonio Indepen-

Salsburg, 346 U.S. at 551 \& n.6.

s5 See North v. Russell, 427 U.S. 328, 338-39 (1976) (quoting Lewis but noting the state's articulated reasons for two-tier trial court system using lay judges in smaller cities); McGowan v. Maryland, 366 U.S. 420, 427 (1961) (curtly relying on Salsburg to uphold variations in Sunday closing laws); Secretary of Agric. v. Central Roig Ref. Co., 338 U.S. 604, 616-19 (1950) (finding sugar quotas for Puerto Rico within congressional discretion).

se See Papasan v. Allain, 106 S. Ct. 2932, 2943-46 (1986) (applying rational basis test to unequal distribution of school land funds to counties); Washington v. Yakima Indian Nation, 439 U.S. 463, 501-02 (1979) (applying rational basis test to "checkerboard jurisdiction" over Indian lands); Holt, 439 U.S. at 70-71 (applying rational basis test to assignment of extraterritorial jurisdiction to municipality); San Antonio Indep. School Dist. v. Rodriguez, 411 U.S. 1, 55 (1973) (applying rational basis test to variations in educational funding); $c f$. Griffin v. County School Bd., 377 U.S. 218, 230-31 (1964) (finding that some reasons may support closing of county schools, but not racial discrimination).

${ }^{87}$ See, e.g., Reeder v. Kansas City Bd. of Police Comm'r, 796 F.2d 1050, 1053-55 (8th Cir. 1986) (stating per se rule in case involving first amendment rights); Walsh v. Massachusetts, 618 F.2d 156, 158-59 (1st Cir. 1980) (applying both rational basis test and per se rule); City of Highland Park v. Train, 519 F.2d 681, 696-97 (7th Cir. 1975) (stating per se rule).

${ }_{88}$ See, e.g., Tarter v. James, 667 F.2d 964, 968-69 (11th Cir. 1982); Laketon Asphalt Ref., Inc. v. United States Dep't of Interior, 624 F.2d 784, 795-96 (7th Cir. 1980); Francis v. Maryland, 605 F.2d 747, 748-49 (4th Cir. 1979); Castillo-Felix v. Immigration and Naturalization Serv., 601 F.2d 459, 467 (9th Cir. 1979); City of New York v. Richardson, 473 F.2d 923, 930 (2d Cir. 1973).

80 See, e.g., Washington v. Yakima Indian Nation, 552 F.2d 1332, 1335 (9th Gir. 1977) (finding no rational basis for state's varying assumption of jurisdiction over Indian lands), rev'd, 439 U.S. 463 (1979); Long v. Robinson, 316 F. Supp. 22 (D. Md. 1970) (finding that statute that classified 16- and 17-year-olds as adults for criminal prosecution in Baltimore, but as juveniles in the rest of the state, violated equal protection), affd, 436 F.2d 1116 (4th Cir. 1971); Peddycoart v. City of Birmingham, 354 So. 2d 808 (Ala. 1978) (finding that statute granting governmental immunity only to the largest city in the state violated equal protection); Bayou Barber College v. Mincey, 193 So. 2 d 610 (Fla. 1967) (finding that statute providing that no barbering school shall be licensed in a county having a population less than 750,000 violated equal protection); State v. Petrovich, 396 So. $2 d 1318$ (La. 1981) (finding that statute permitting only certain levee districts to employ special counsel without approval of state attorney general violated equal protection). 
dent School District v. Rodriguez, ${ }^{60}$ and shortly thereafter, the Court summarily affirmed a judgment invalidating as irrational Louisiana's scheme for distribution of tax relief to parishes. ${ }^{61}$

Strict scrutiny of territorial classifications affecting fundamental rights blossomed after 1964 in the voting rights decisions. At the same time that the Court was invalidating explicit intrastate residence discriminations, ${ }^{62}$ it found that the allocation of disproportionate voting strength to political subdivisions violated equal protection. ${ }^{63}$ The Court also condemned ballot access requirements for city elections that were stricter than the requirements for statewide elections. ${ }^{64}$ In short, the Court had retreated significantly from the rule of per se legality of territorial classifications.

The best illustration of this retreat is the unhesitating readiness of eight Justices in Rodriguez to extend strict scrutiny to territorial classifications infringing upon other fundamental rights. ${ }^{65}$ The entire Court recognized the need to examine the rationality of the territorial discrimination and the majority explored it at length. ${ }^{66}$ Only the weakest echo of the Lewis dictum survived: "This Court has never doubted the propriety of maintaining political subdivisions within the states and has never found in the Equal Protection Clause any per se rule of 'territorial uniformity." "'67

${ }^{30} 411$ U.S. 1, 63-70 (1973) (White, J., dissenting). Justice Marshall, however, characterized his fellow dissenters as applying a closer form of scrutiny. See id. at 129 n.96 (Marshall, J., dissenting). 1972).

oi See Parker v. Levy, 411 U.S. 978 (1973), aff g 346 F. Supp. 897 (E.D. La.

os See, e.g., Evans v. Cornman, 398 U.S. 419 (1970) (invalidating application of Maryland voter residency law that disqualified persons who lived on a federal enclave from voting in the state); Moore v. Ogilvie, 394 U.S. 814 (1969) (holding that an Illinois signature requirement to become an independent candidate in the state discriminated against the residents of populous counties in violation of the equal protection clause).

os See, e.g., Lucas v. Forty-Fourth Colo. Gen. Assembly, 377 U.S. 713 (1964); Reynolds v. Sims, 377 U.S. 533 (1964). (1979).

See Illinois State Bd. of Elections v. Socialist Workers Party, 440 U.S. 173

os A five-Justice majority held that education was not a fundamental right but agreed that the equal protection clause would require strict scrutiny of radically unequal distribution of educational funding if it were. See 411 U.S. at 17. Three dissenters insisted that education was indeed a fundamental right, and that strict scrutiny therefore applied. See id. at 63 (Brennan, J., dissenting); id. at 125-26 (Marshall, J., joined by Douglas, J., dissenting). Justice White, who found the Texas system wholly irrational and therefore a violation of equal protection, see id. at 64-65 (White, J., dissenting), did not expressly address the strict scrutiny question.

os See id. at 44-55; see also Papasan v. Allain, 106 S. Ct. 2932 (1986) (reversing dismissal of rational basis equal protection attack on Mississippi's distribution of public school land funds to counties).

${ }^{67}$ Rodriguez, 411 U.S. at 54 n.110. 


\section{B. A Volume of Logic}

Territorial classifications should be no more exempt from the mandate of equal protection than any other nonsuspect classification. The state must provide some explanation for declaring one law at Rome and another at Athens. But when these discriminations hew to political boundary lines, justifications for their existence are easily hypothesized. From the time of Missouri v. Lewis, courts have recognized that too rigid an equal protection analysis would deprive the state of flexibility in structuring its institutions and parceling out authority to local governments. The pivotal questions thus become how much weight these proffered justifications will bear, and how much they need to bear.

The following section will discuss fundamental rights equal protection and why its concerns extend to territorial discrimination. Because territorial discriminations should presumptively be treated no differently than any other nonsuspect classification, fundamental rights equal protection questions may arise in several contexts where they are commonly overlooked. I will argue that in some of these areas the discriminations should be regarded as unconstitutional, but that in others the equal protection methodology should be modified to excuse the discriminations from heightened scrutiny. The problem is to accommodate locally chosen diversity without rendering equal protection as ineffective a safeguard against territorial discrimination as it was in the era of Missouri v. Lewis.

\section{Fundamental Rights and Equal Protection}

Several clauses of the Constitution may forbid territorial discrimination with respect to fundamental rights. Most obviously, territorial classifications drawn by a state legislature, or by any of the state's judicial, executive, or municipal agents, implicate the equal protection clause of the fourteenth amendment. ${ }^{68}$ Those created by Congress or by any agent of the federal government or its territories trigger a form of equal protection analysis under the due process clause of the fifth amendment. ${ }^{69}$ But these are not the only sources of nondiscrimination principles. Individual grants of power to Congress sometimes contain express uniformity requirements, which may impose limits on territorial discrimination by the federal government stricter than those equal

${ }^{88}$ See Yick Wo v. Hopkins, 118 U.S. 356 (1886); Ex parte Virginia, 100 U.S. 339 (1880).

${ }^{89}$ See Rodriguez v. Popular Democratic Party, 457 U.S. 1 (1982); Examining Bd. v. Flores de Otero, 426 U.S. 572 (1976); Bolling v. Sharpe, 347 U.S. 497 (1954). 
protection itself requires. ${ }^{70}$ In addition, state discrimination based on out-of-state residence may violate the commerce clause or the privileges and immunities clause of article IV.

Broad equal protection principles may also be inherent in some guarantees of substantive rights that are susceptible to competitive injury. For example, denying an arbitrarily chosen group access to a forum open to all others may create a greater obstacle to that group's reaching its desired audience than closing the forum altogether. ${ }^{\text {11 }}$ Moreover, the very fact that one group has been permitted fuller exercise of a right may, as an evidentiary matter, undercut the state's claim that it is necessary or reasonable to restrict its exercise by others. Thus, scrutiny under the constitutional provisions directly addressing the right (I will call this "direct substantive review") can provide a fair substitute for equal protection scrutiny in such cases.

One may therefore question why equal protection analysis should ever be applied in cases involving fundamental rights already protected by the Constitution. Indeed, the "fundamental rights branch" of equal protection has been criticized roundly. Although my major purpose here is to qualify the doctrine, and not to praise it, there may be some value in briefly restating its defense.

The fundamental rights branch emerged against the background of the "old" equal protection, which, with rare exceptions, applied the most minimal scrutiny to the reasonableness of a classification chal-

${ }^{70}$ See, e.g., United States v. Ptasynski, 462 U.S. 74 (1983) (tax uniformity clause, U.S. ConST. art. I, §8, cl. 1); Railway Labor Executives Ass'n v. Gibbon, 455 U.S. 457 (1982) (bankruptcy uniformity clause, U.S. Const. art. I, §8, cl. 4); Head Money Cases, 112 U.S. 580 (1884) (port preference clause, U.S. CoNST. art. I, \$9, cl. 6); Petition of Lee Wee, 143 F. Supp. 736 (S.D. Cal. 1956) (naturalization uniformity clause, U.S. Const. art. I, §8, cl. 4). The Supreme Court has sometimes found implicit requirements of uniformity in other constitutional provisions. See Knickerbocker Ice Co. v. Stewart, 253 U.S. 149 (1920) (maritime law under article III and the necessary and proper clause); Coyle v. Smith, 221 U.S. 559 (1911) (equal footing doctrine with regard to admission of new states under article IV, $\S 3$, cl. 1). None of these specialized uniformity provisions will be addressed in this Article.

71 Thus, the nondiscrimination principles implicit in freedom of speech go beyond a ban on express content discrimination, and render suspect many discriminations among speakers. See, e.g., Karst, Equality as a Central Principle in the First Amendment, 43 U. CHI. L. REv. 20, 37 (1975) (stating that content-neutral restrictions may have differential impact on different speaker groups, resulting in de facto content discrimination offensive to the first amendment). Other constitutional rights may be less susceptible to such competitive injury. For example, infringement of a teenager's right to use contraceptives is not intensified by allowing adults to use them. The right to marry is susceptible to competitive injury only in the narrow sense that if you don't marry Roxanne quickly someone else may. See also Simons, Equality as a Comparative Right, 65 B.U.L. REv. 387, 467-70 (1985) (arguing that fundamental rights equal protection and due process approaches lead to same results only when underlying rights are "comparative" rather than absolute). 
lenged as discriminatory. ${ }^{72}$ The exceptions expanded over the course of the Warren Court years and crystallized into the two-tier system of the "new equal protection." The lower tier perpetuated the traditional deferential scrutiny afforded in ordinary cases, while the second, higher tier subjected exceptional cases to a demanding "strict scrutiny."

The exceptional cases were of two kinds: those involving classifications suspect in themselves, like race or national origin, and those where otherwise unremarkable classifications affected the exercise of a fundamental right, like the right to vote. The Supreme Court described this framework as a discrete set of pigeonholes, but some writers, most prominently Justice Marshall, envisioned it as bounding a two-dimensional continuum - the "sliding scale"-in which the intensity of judicial scrutiny increased continuously as a function of both the suspectness of the classification itself and the importance of the interest being denied to the disfavored class. ${ }^{74}$ Over the last decade, the Supreme Court has burst the bounds of the rigid two-tier system without openly replacing it with a sliding scale method or with anything else. ${ }^{75}$ Nonetheless, it remains safe to say that the impact of a legislative classification on certain fundamental constitutional rights will trigger a higher level of equal protection scrutiny than the Court employs in an "ordinary" equal protection case. ${ }^{76}$

72 This is true at least in theory. As the dissenters pointed out at the time, it is hard to perceive the arbitrariness of the classifications condemned in such "traditional" cases as Frost v. Corporation Comm'n, 278 U.S. 515 (1929); Truax v. Corrigan, 257 U.S. 312 (1921); or the much cited F.S. Royster Guano Co. v. Virginia, 253 U.S. 412 (1920).

${ }^{73}$ See Shapiro v. Thompson, 394 U.S. 618 (1969); Developments in the Law-Equal Protection, 82 HaRv. L. Rev. 1065, 1076-77 (1969) [hereinafter Developments-Equal Protection].

${ }^{74}$ See, e.g., Rodriguez, 411 U.S. at 98-110 (Marshall, J., dissenting); Dandridge v. Williams, 397 U.S. 471, 520-21 (1970) (Marshall, J., dissenting).

${ }_{75}$ See, e.g., Plyler v. Doe, 457 U.S. 202, 223-24 (1982); Craig v. Boren, 429 U.S. 190 (1976). For expressions of dissatisfaction with the two-tier approach by individual justices, see City of Cleburne v. Cleburne Living Center, 105 S. Ct. 3249, 3260-62 (1985) (Stevens, J., concurring); id. at 3263 (Marshall, J., concurring in part and dissenting in part); Plyler, 457 U.S. at 232-34 (Blackmun, J., concurring in the judgment); Zablocki v. Redhail, 434 U.S. 374, 396-97 (1978) (Powell, J., concurring).

${ }^{76}$ I should also point out the existence of equal protection approaches that reject the notion of levels of scrutiny altogether, and call for a holistic examination of particular discriminations to determine directly whether, under all the circumstances, the government's action offends the relevant notion of "impartiality" or "equality." Justice Stevens has argued for such an approach. See, e.g., City of Cleburne, 105 S. Ct. at 3261 n.4 (Stevens, J., concurring); Clements v. Fashing, 457 U.S. 957, 973-76 (1982) (Stevens, J., concurring); Western \& S. Life Ins. Co. v. Board of Equalization, 451 U.S. 648, 677-78 (1981) (Stevens, J., dissenting); Michael M. v. Superior Court, 450 U.S. 464, 502 (1981) (Stevens, J., dissenting); see also Baker, Outcome Equality or Equality of Respect: The Substantive Content of Equal Protection, 131 U. PA. L. REV. 933 (1983) (arguing for an "equality of respect" interpretation of equal protection, 
Justice Marshall's sliding scale differs from the Court's announced doctrine not only by inserting gradations of strictness between minimum and maximum scrutiny, but also by allowing important "interests" that are not independently constitutional "rights" to trigger heightened scrutiny. This contrast may be sloganized by distinguishing between the "substantive equal protection" approach, in which the equal protection clause itself becomes the authority for elevating interests like housing or education to extraordinary constitutional status, and the "fundamental rights equal protection" approach, in which values receiving extraordinary protection under the equal protection clause must be derived from some other source in the Constitution. Of course, to the extent that the other source is the doctrine of substantive due process, these two approaches may be hard to tell apart, but as long as the Court is willing to scrutinize the relative distribution of interests it will not protect directly as rights, "substantive equal protection" is a broader theory.

The Court purported to reject decisively the substantive equal protection approach in San Antonio Independent School District v. Rodriguez, ${ }^{77}$ while approving of fundamental rights equal protection analysis with regard to rights "explicitly or implicitly guaranteed by the Constitution."78 Although the Court's unwavering fidelity to this standard may be doubted, ${ }^{78}$ I will limit my attention here to the orthodox formulation of fundamental rights equal protection as expounded in Rodriguez. Rather than predict the future of the tier versus sliding-scale controversy, or untie this Gordian knot myself, I shall for descriptive purposes throughout this Article take advantage of the common ground between those rival approaches: that the impact of a classification on a fundamental right intensifies the level of judicial scrutiny beyond the traditional minimum to some version of "heightened scrutiny."

In either form, a key characteristic of fundamental rights equal protection is its ability to focus on discriminations in the distribution of fundamental rights. The state may justifiably restrict the exercise of fundamental rights, but it must do so evenhandedly. A state restriction on the exercise of a fundamental right that might have survived direct substantive review if uniformly applied may violate equal protection if

guaranteeing right to political participation, access to resources deemed necessary for full participation in the community, and protection against purposeful subordination). The present Article does not deal with such approaches, which require discussion of equal protection issues in an entirely different manner that would greatly change the analysis.

77411 U.S. at 30-34.

78 Id. at 33-34.

79 See, e.g., Plyler, 457 U.S. at 202; Griffin v. Illinois, 351 U.S. 12 (1956). 
it restricts only the exercise of the right by a particular group, ${ }^{\mathbf{8 0}}$ or the exercise of the right in particular contexts. ${ }^{81}$ To give a crude example, it has been assumed that the state can impose a minimum age restriction on the right to marry; $;^{\mathbf{2}}$ but if the state imposes different age restrictions on different groups-for example, if high school graduates may marry at seventeen, but others must wait until nineteen-then the discrimination may violate equal protection even if a uniform age of seventeen or nineteen would have been constitutional. The state has authority to vary some of the contours of a fundamental right by asserting or failing to assert countervailing interests, but equal protection concerns are raised when the contours are not the same for all.

Four major criticisms of fundamental rights equal protection echo through the literature. One basic ground of attack is that protection of fundamental rights has nothing to do with "equal protection" at all. ${ }^{83}$ A second is that fundamental rights equal protection gives judges an illegitimate opportunity to elevate above the political process those interests that they personally favor. ${ }^{84}$ Third, fundamental rights equal protection has been called redundant, merely duplicating protection already afforded by direct substantive review. ${ }^{85}$ Fourth, in contrast with number three, fundamental rights equal protection has been described as too rigid because it does not permit the state the necessary flexibility that survives the more malleable particularistic analysis of direct substantive review. ${ }^{86} \mathrm{I}$ will take these criticisms up in this order.

${ }^{80}$ See, e.g., Zablocki v. Redhail, 434 U.S. 374, 388-91 (1978) (finding that statute that restricted the right to marry of those subject to court child support orders violates the equal protection clause); Garrington v. Rash, 380 U.S. 89, 96-97 (1965) (finding that the denial of franchise to armed services members stationed locally violates equal protection).

81 See, e.g., Carey v. Brown, 447 U.S. 455 (1980) (finding that statute distinguishing peaceful labor picketing in residential areas from other peaceful picketing violated the equal protection clause); Illinois State Bd. of Elections v. Socialist Workers Party, 440 U.S. 173, 183-87 (1979) (finding that greater signature requirements to gain access to the ballot in city elections than in statewide elections violated equal protection).

${ }_{82}$ See, e.g., Zablocki, 434 U.S. at 398-99 (Powell, J., concurring).

s3 See, e.g., id. at 391 (Stewart, J., concurring); P. Polyviou, The EQual ProTECTION OF THE LAws 189-91 (1980); Lupu, Untangling the Strands of the Fourteenth Amendment, 77 MrCH. L. Rev. 981, 1075-77 (1979); Perry, Modern Equal Protection: A Conceptualization and Appraisal, 79 Colvm. L. REv. 1023, 1074-77 (1979).

84 See, e.g., P. Polyviou, supra note 83, at 189-90; Lupu, supra note 83, at 983, 1076; Wilkinson, The Supreme Court, the Equal Protection Clause, and the Three Faces of Constitutional Equality, 61 VA. L. REv. 945, 1017 (1975).

${ }_{8 B}$ See, e.g., Shapiro v. Thompson, 394 U.S. 618, 659, 662 (1969) (Harlan, J., dissenting); J. Nowak, R. Rotunda \& T. Young, Constitutional Law 817-819 (2d ed. 1983) [hereinafter J. Nowak].

${ }^{88}$ See, e.g., Zablocki v. Redhail, 434 U.S. 374, 395-96 (1978) (Stewart, J., con- 
The first complaint, that fundamental rights equal protection is not "properly speaking" equal protection at all, is often accompanied by the vehemence endemic to academic definitional disputes. ${ }^{87}$ Of course, to understand this argument, one must know what, "properly speaking," equal protection is. The criticism normally rests on one of two foundational viewpoints: unswerving faith that precedent correctly limits equal protection review to analyzing the peculiarities of legal "classifications," or the identification of equal protection with some legal or philosophical notion of "equality."

The first of these axioms, emphasizing the centrality of "classifications," will crop up more than once in this Article, and requires close attention for a moment. As everyone knows, the equal protection clause was drafted with the paradigm of racial discrimination in mind, but the breadth of its language cried out for wider application. Early on, the Supreme Court denied that the clause demanded total, unreasoning identicalness of treatment. Rather, legislatures could adopt reasonable classifications. Distinguishing between reasonable and arbitrary legislative classifications thus became the most frequent issue in the equal protection caseload. The highly influential article of Tussman and tenBroek elaborated equal protection technique primarily in the context of such classifications. ${ }^{88}$

Let us formalize a typical equal protection case as follows: the state, by some form of government action $A$, allocates to group $G$ the burden or benefit $B$, and to the rest of society $G$ ' the burden or benefit $B$ '. The classification, $\mathrm{C}$, is the rule assigning individuals to group $\mathrm{G}$ or group $G^{\prime 89}$ Following Tussman and tenBroek, modern writers have looked to the nature of the classification $\mathrm{C}$, and the closeness of fit between it and the legislature's underlying purpose, $\mathrm{P} .{ }^{80}$ In the original two-tier system, the closeness of fit required by equal protection analysis depended on whether the classification $\mathrm{C}$ or the difference between

curring); Williams v. Rhodes, 393 U.S. 23, 43 (1968) (Harlan, J., concurring); P. Polyviou, supra note 83, at 189-90; Westen, The Empty Idea of Equality, 95 HARv.

L. REv. 537, 585 (1982).

82 See, e.g., Lupu, supra note 83; Perry, supra note 83.

88 See Tussman \& tenBroek, supra note 27 , at 341 . The authors recognized that equal protection constrained administrative actions as well. See id. at 353. Tussman and tenBroek also identified the possibility of a "substantive equal protection" doctrine, but did not perceive it as a method of demanding more from classifications. Rather, they viewed it as forbidding particular legislative purposes. See id. at 361-67. The cases they viewed as "substantive" would fall within the suspect classification category today, since the overthrow of "separate but equal."

Bo Schematically, letting $S$ represent all of society:

$S \stackrel{\mathrm{C}}{\rightarrow}\left\{\mathrm{G}, \mathrm{G}^{\cdot}\right\} \mathrm{A}\left\{\mathrm{B}, \mathrm{B}^{\cdot}\right\}$

${ }^{\circ}$ See Tussman \& tenBroek, supra note 27 , at 367. 
B and B' involved a fundamental right or a "suspect" class. In Justice Marshall's sliding-scale model, the intrusiveness of review depends on both the nature of the classification $\mathrm{C}$ and the difference between $\mathrm{B}$ and B'. I will discuss later in this Article claims that equal protection concerns are implicated only in cases involving certain kinds of classifications $\mathrm{C}$, or only in cases involving certain kinds of actions $\mathrm{A}$. The issue at present is the criticism directed against fundamental rights equal protection that whether equal protection concerns are implicated should properly depend only on the nature of the classification $\mathrm{C}$, and not on the difference between $B$ and $B^{\prime}{ }^{91}$

The Supreme Court, in contrast, has identified precisely such differences as a valid subject of equal protection solicitude:

"Due process" emphasizes fairness between the State and the individual dealing with the State, regardless of how other individuals in the same situation may be treated. "Equal protection," on the other hand, emphasizes disparity in treatment by a State between classes of individuals whose situations are arguably indistinguishable. ${ }^{22}$

The roots of this observation run deep in the Court's history. Once it extended the clause beyond the unique problem of race, the Court was forced to recognize that distinctions wholly innocuous in one context might amount to "clear and hostile discriminations" in another. The Court first applied this broadened doctrine to legislation directed against the railroads, an area where "unreasonable" discriminations were more likely to be produced by calculating ill will than by inadvertent error. ${ }^{94}$ Soon thereafter, the Court found the importance of the

01 See, e.g., Perry, Equal Protection, Judicial Activism, and the Intellectual Agenda of Constitutional Theory: Reflections on, and Beyond "Plyler v. Doe", 44 U. PITT. L. Rev. 329, 340 \& n.47 (1983).

${ }_{92}$ Ross v. Moffitt, 417 U.S. 600, 609 (1974).

93 Bell's Gap R.R. v. Pennsylvania, 134 U.S. 232, 237 (1890).

o4 See Gulf C. \& S.F. Ry. v. Ellis, 165 U.S. 150, 156-57 (1897); Chicago, M. \& St. P. Ry. v. Minnesota, 134 U.S. 418, 458 (1890); Kay, The Equal Protection Clause in the Supreme Court 1873-1903, 29 Bufralo. L. REv, 667, 701-02 (1980). For criticisms of the "mistake" theory of equal protection, see for example, Baker, Neutrality, Process, and Rationality: Flawed Interpretations of Equal Protection, 58 TEx. L. REv. 1029, 1034-35 (1980); Cohen, Transcendental Nonsense and the Functional Approach, 35 Colum. L. Rev. 809, 819 (1935); Linde, Due Process of Lawmaking, 55 NEB. L. REv. 197 (1976); Tribe, Foreword: Toward a Model of Roles in the Due Process of Life and Law, 87 HaRv. L. REv. 1, 6 \& n.28 (1972). As my purpose here is to discuss fundamental rights equal protection, I will not dwell on the problem of understanding rationality review. But cf. A. ConAN DoyLe, The Sign of the Four, in The Annotated Sherlock Holmes 610, 638 (W. Baring-Gould 2d ed. 1967) ("W]hen you have eliminated the impossible, whatever remains, however improbable, must be the truth.") (emphasis deleted). 
right being denied a relevant indicator of arbitrary discrimination. ${ }^{95}$ It is thus historically inaccurate to view equal protection analysis as focused solely on the nature of classifications.

Nor is it immediately clear that fundamental rights have nothing to do with a proper normative conception of equality. If we deny the blind the right to practice medicine and the right to vote, are notions of equality implicated to the same degree? ${ }^{98} \mathrm{Or}$, in our constitutional democracy, is refusal of the franchise itself a brand of inequality, a denial of respect and full equality of status? ${ }^{\text {97 }}$ As other writers have more eloquently argued, the concept of equality may plausibly be thought to entail equal participation in those liberties society considers fundamental. ${ }^{98}$ If so, it is no misnomer to scrutinize under the rubric of "equal protection" a differential restriction on the exercise of fundamental rights. ${ }^{98}$ However equal protection is viewed, as imposing some sub-

9s See, e.g., Truax v. Corrigan, 257 U.S. 312 (1921) (right to enjoy property and engage in business free from tortious interference); Truax v. Raich, 239 U.S. 33 (1915) (right to work for a living in the common occupations of the community). These cases long antedated Skinner v. Oklahoma ex rel Williamson, 316 U.S. 535 (1942) (strictly scrutinizing infringement of right to procreation).

${ }^{\circ}$ Professor Perry, if I read him correctly, would reserve heightened scrutiny under the equal protection clause for classifications based on "morally irrelevant" traits, which do not include traits relating to a person's physical capacity. See Perry, supra note 83, at 1065-67. Nor do they include classifications based on a person's voluntary acts such as sexual preference. See id. His theory as to the nature of equality renders laws based on such classifications wholly unsuitable for equal protection analysis.

${ }^{97}$ See Reynolds v. Sims, 377 U.S. 533, 567 (1964) ("To the extent that a citizen's right to vote is debased, he is that much less a citizen.").

${ }^{98}$ See, e.g., Baker, supra note 76, at 963-64; Karst, Foreword: Equal Citizenship Under the Fourteenth Amendment, 91 HARv. L. REv. 1, 26-34 (1977); cf. Skinner, 316 U.S. at 541 ("When the law lays an unequal hand on those who have committed intrinsically the same quality of offense and sterilizes one and not the other, it has made as invidious a discrimination as if it had selected a particular race or nationality for oppressive treatment.").

92 This argument does not explain, however, the category of fundamental rights equal protection holdings based on the conclusion that a state has "penalized" the exercise of a fundamental right. The "penalization" rhetoric suggests that the Court detects hostility to the class of persons who have exercised a particular fundamental right or exercised it in a particular way, making these cases more like suspect classification cases than like fundamental rights cases. Certainly the situations in Shapiro v. Thompson, 394 U.S. 618, 660, 661 \& n.9 (1969) (Harlan, J., dissenting), and Maher v. Roe, 432 U.S. 464, 487-88 (1977) (Brennan, J., dissenting), (although the plaintiffs lost in the latter case) are susceptible to such an interpretation. Religious minorities straddle the line between suspect class theory and fundamental rights theory and may provide the aptest analogy. See United States v. Carolene Prods. Co., 304 U.S. 144, 152 n.4 (1938); $c f$. Hunter v. Erickson, 393 U.S. 385, 389-91 (1969) (finding that a charter amendment making it more difficult to enact bans on racial or religious discrimination in housing than to enact other housing legislation violated equal protection). For an argument that the "penalization" cases do not really involve equality issues, see Simons, supra note 71 , at $462-67$. 
stantive notion of equality, as a safeguard against subjective hostility, or as a prohibition of disrespectful inattention to one's interests, discriminations affecting fundamental rights call for closer scrutiny.

The second criticism, involving value imposition, has been defused somewhat by the Supreme Court's repudiation of the broader doctrine of substantive equal protection. ${ }^{100}$ Nonetheless there may still be room for an independent criticism to the extent that the Court picks and chooses among constitutional rights for elevation to a privileged status as equal protection fundamental rights. Freedom of speech and the right to marry have achieved this status, but thus far the right to bear arms, the right to just compensation for takings of private property, and rights under the contract clause have not. ${ }^{101}$ Furthermore, some Justices have argued that different fundamental rights should evoke different levels of heightened scrutiny under the equal protection clause. ${ }^{\mathbf{1 0 2}}$ Gommentators have also noted the unpredictability of the Court's choice of which analysis, equal protection or direct substantive review, to employ in given cases. ${ }^{103}$

In large part, this kind of discretionary judicial action is the inevitable reflection of the preferred liberties method of direct substantive review. There is presently a hierarchy of constitutional rights receiving varying degrees of protection, and whatever justifies this hierarchy in the sphere of direct substantive review may be thought to justify it in the equal protection sphere as well. Yet it is unclear how fully the hierarchy of equal protection mirrors this other hierarchy. Oddly enough, the majority that rejected the substantive equal protection approach in Rodriguez has never seen fit to provide its own explanation of why some or all rights "explicitly or implicitly guaranteed by the Constitution" should raise special problems for equal protection. Jus-

100 Certainly the Court thought so. See Rodriguez, 411 U.S. at 30-34. Of course, this repudiation was contemporaneous with the undisguised reemergence of substantive due process, and any criticism of judicial value choice under the due process rubric would apply with similar force to corollary holdings under the equal protection clause.

101 For example, the Supreme Court has held that a state's legislation derogating from the obligation of its own contracts triggers closer judicial scrutiny than impairment of private contract obligations, but the Court has not yet applied heightened equal protection scrutiny to a state's decision to impair some public contracts while respecting others. See Exxon Corp. v. Eagerton, 462 U.S. 176, 195-196 (1983) (applying rational basis test to impairment of private contracts); $c f$. Stearns v. Minnesota, 179 U.S. 223, 262 (1900) (White, J., concurring) (finding that impairment of public contract was arbitrary and violated equal protection); Duluth \& I.R.R.R. v. Saint Louis County, 179 U.S. 302, 305 (1900) (same).

${ }_{102}$ See Zablocki v. Redhail, 434 U.S. 374, $397-400$ (Powell, J., concurring) (1978); id. at $406 \&$ n.10 (Stevens, J., concurring).

${ }_{103}$ See, e.g., J. Nowak, supra note 85, at 817; Lupu, supra note 83, at 1017-18, 1026. The one thing that can safely be said is that the Court does not reserve equal protection analysis for cases uniquely turning on classification problems. 
tice Marshall, who has never accepted Rodriguez as either normatively or descriptively correct, has continued to insist that importance to the individual, the factor on which the earlier fundamental interests holdings were based, still governs the Court's decisions. ${ }^{104}$ It may be that after Rodriguez this "importance" theory is still operative, at least in choosing among independently protected fundamental rights; or it may be time for the Court to explain which rights constitute "just wants" or otherwise determine in some essential way the equality of persons mandated by the fourteenth amendment. ${ }^{105}$ Perhaps the best response to the second criticism, then, is that the discretion involved in fundamental rights equal protection may result from the incompleteness of its articulation. The approach may presently be subject to abuse, but it does not inherently lead to abuse.

The third and fourth criticisms, redundancy and rigidity, are complementary, and their tension reflects uncertainty over how fundamental rights equal protection is applied. If the equal protection analysis duplicated identically the analysis that would otherwise be pursued under some other rubric, then the doctrine would have nothing to offer. If the equal protection analysis were stricter, then some would find it too rigid. I believe the correct response is that equal protection analysis can provide a more powerful check on discriminations respecting fundamental rights than direct substantive review affords, and that this greater stringency is appropriate. The difference lies in the observation of then Justice Rehnquist already quoted: " 'Due process' emphasizes fairness between the State and the individual dealing with the State, regardless of how other individuals in the same situation may be treated." 108 This emphasis may be hard to justify in principle, and may not accurately represent the Court's conduct in every case, ${ }^{107}$ but too often courts act exactly as Justice Rehnquist described. ${ }^{108}$ Even when

104 See, e.g., Harris v. McRae, 448 U.S. 297, $341-42$ (1980) (Marshall, J., dissenting); Vance v. Bradley, 440 U.S. 93, 115 (1979) (Marshall, J., dissenting); Massachusetts Bd. of Retirement v. Murgia, 427 U.S. 307, 318-20 (1976) (Marshall, J., dissenting).

${ }^{103}$ Cf. Plyler v. Doe, 457 U.S. 202, 234 (1982) (Blackmun, J., concurring) ("IA]ccepting the principle of the voting cases-the idea that state classifications bearing on certain interests pose the risk of allocating rights in a fashion inherently contrary to any notion of 'equality'-dictates the outcome here.").

${ }_{106}$ Ross v. Moffitt, 417 U.S. 600, 609 (1974) (emphasis added); see also Simons, supra note 71 , at $467-72$ (fundamental rights equal protection as an example of a "comparative right").

${ }_{107}$ See, e.g., Minneapolis Star \& Tribune Co. v. Minnesota Comm'r, 460 U.S. 575, 585-88 (1983); Larson v. Valente, 456 U.S. 228, 245-46 (1982); First Nat'l Bank of Boston v. Bellotti, 435 U.S. 765, 793-95 (1978); City of Madison School Dist. v. Wisconsin Empl. Relations Comm'n, 429 U.S. 167, 174-76 (1976).

${ }^{108}$ See, e.g., Members of City Council v. Taxpayers for Vincent, 466 U.S. 789, 
courts engaged in direct substantive review notice an inconsistency in the state's treatment of similarly situated persons, they do not always treat the discrimination as directly relevant to the validity of the limitation on the plaintiff's rights. Inconsistency may, as an empirical matter, undercut the strength of the state's claim that restricting the plaintiff's actions is necessary or serves a compelling interest, but the state is not called upon to demonstrate the need for this differential treatment. ${ }^{109}$

When the majority denies to some group fundamental constitutional liberties that it preserves untrammeled for itself, or allows those liberties to be exercised only in the modes that it prefers, direct and searching scrutiny of the discrimination should be required. Hostility, domination, or disregard may have led the majority to subordinate the minority's rights to interests that it would not consider as outweighing its own rights. The doctrine of fundamental rights equal protection ensures such scrutiny and allows the courts to invalidate in their actual context unequal restrictions that might have been upheld if viewed in isolation or if universally applied. ${ }^{110}$

There is nothing novel in the observation that equal protection analysis encourages circumspection by forcing sacrifices to be shared. In Justice Jackson's classic formulation,

The framers of the Constitution knew, and we should not forget today, that there is no more effective practical guaranty against arbitrary and unreasonable government than to require that the principles of law which officials would impose upon a minority must be imposed generally. ${ }^{111}$

Universal renunciation of a fundamental right is particularly unlikely. "Everyone at some time or other loves a parade," as Harry Kalven reminded us. "Equal protection may, therefore, require freedom for the

808-812 (1984); United States v. Lee, 455 U.S. 252, 260-61 (1982); H.L. v. Matheson, 450 U.S. $398,412-13$ (1981).

${ }_{108}$ Professor Lupu makes precisely this point, and applauds.it, arguing that justification of nonsuspect discriminations regarding fundamental rights should never be required, under due process or equal protection theories. See Lupu, supra note 83, at 1001 n.98, 1073.

${ }_{110}$ See, e.g., Carey v. Brown, 447 U.S. 455, 470-71 (1980) (finding that the state's interest in "preserving the sanctity of the home" may be a reason to curtail picketing in residential areas, but only if in so doing the state does not "discriminate[] among pickets based on the subject matter of their expression"); Williams v. Rhodes, 393 U.S. 23, 30-34 (1969) (finding that state has "broad powers to regulate voting which may include laws relating to the qualification and functions of electors," but the state may not impose unequal restriction so as to give established political parties an advantage over new parties).

${ }_{111}$ Railway Express Agency v. New York, 336 U.S. 106, 112 (1949) (Jackson, J., concurring). 
parades we hate."112 Fundamental rights equal protection is thus neither redundant nor overly rigid-it is the necessary safeguard against discrimination in the areas that matter most.

\section{The Need for Scrutiny of Geographical Discrimination: With Apologies for Some Jargon}

The various forms of geographical discrimination can raise the dangers that fundamental rights equal protection addresses. Unfortunately, I must introduce some additional terminology regarding categories of geographical discriminations, in order to anticipate likely criticisms of the more unified treatment of geographical discrimination that will follow. In candor, then, I should distinguish among three categories of geographical discriminations. The first are "explicit residence discriminations," which expressly restrict a given benefit or burden to the residents of a particular region. For example, states commonly limit free public education in each school district to residents of that district. ${ }^{113}$ The second category consists of "pure location discriminations," those in which the allocation of benefits and burdens does not depend on the residence of any person, but rather on other geographical factors. For example, a form of zoning that prohibited all theatrical performances within a certain county, while permitting them in the rest of the state, would be a pure location discrimination. ${ }^{114}$

The third category is a hybrid, the "indirect residence discriminations," resulting from the interaction between explicit residence discriminations and pure location discriminations. For example, suppose that a state has two school districts. Residents of each school district can attend without tuition only the schools of their district. Suppose further that after a scandalous performance in one district, the State Commissioner of Education issues a directive to that district, forbidding its schools to stage or to teach drama. The directive on its face discriminates between institutions, not residents, but as a result of the pupil allocation system it creates an indirect de jure residence discrimination.

112 Kalven, The Concept of the Public Forum, 1965 SuP. CT. Rev. 1, 30 (1966).

11s See, e.g., Martinez v. Bynum, 461 U.S. 321, 329-30 (1983) (upholding such a restriction). The Court has suggested its approval of simple residence requirements for certain government benefits, even while striking down durational residence requirements. See, e.g., Memorial Hosp. v. Maricopa County, 415 U.S. 250, 255 (1974) (invalidating one-year residence requirement as a condition for receipt of free medical care but not intending to "cast doubt on the validity of appropriately defined and uniformly applied bona fide residence requirements' ") (quoting Dunn v. Blumstein, 405 U.S. 330,342 n.13 (1972)).

114 Cf. Schad v. Borough of Mount Ephraim, 452 U.S. 61 (1981) (invalidating on first amendment grounds a prohibition on live entertainment throughout municipality). 
Indirect residence discriminations are frequently mediated by a geographically limited government institution. Attendance rules, venue rules, and voter residence rules can convert distinctions between school, judicial, and electoral districts into distinctions between residents. Because by their terms they address things and not people, courts often have treated them as especially inoffensive to equal protection principles. $^{115}$

These latter two categories, the pure location discriminations and the indirect residence discriminations, together comprise the class I have earlier called territorial discriminations. The explicit and indirect residence discriminations, taken together, may be called "residence discriminations." All these categories, taken together, exhaust the forms of "geographical discriminations." Examples of indirect residence discriminations affecting fundamental rights include the reapportionment cases, ${ }^{116}$ and (if education were a fundamental right) the school finance cases. ${ }^{117}$ Examples of pure location discriminations affecting fundamental rights include defamation laws whose stringency depends on the place where the communication is received, ${ }^{118}$ bans on picketing in certain neighborhoods, ${ }^{119}$ and zoning regulations excluding certain kinds of families from specified areas. ${ }^{\mathbf{1 2 0}}$

It is important to recognize that when an explicit residence discrimination and a pure location discrimination combine to create an indirect residence discrimination, the constitutionality of the components viewed separately does not guarantee the constitutionality of the combination. For example, a state could adopt venue rules limiting actions brought by state residents to the county of the plaintiff's residence.

118 See, e.g., Washington v. Yakima Indian Nation, 439 U.S. 463, $499-502$ (1979) (upholding statute conferring "checkerboard" jurisdiction over Indian territory against equal protection challenge); Holt Civic Club v. City of Tuscaloosa, 439 U.S. 60, 70-75 (1978) (upholding "police jurisdiction" statutes that extended municipal police, sanitary, and business licensing powers over those residing within three miles of corporate boundaries without permitting such residents to vote in municipal elections); $c f$. Griffin v. County School Bd., 377 U.S. 218, 230-31 (1964) (rejecting closing of public schools and subsequent opening of all-white private schools in one county after desegregation order, although noting that a state has wide discretion to make laws applicable only in certain counties).

116 See, e.g., Reynolds v. Sims, 377 U.S. 533 (1964).

117 See Rodriguez, 411 U.S. at 1; Serrano v. Priest, 18 Cal. 3d 728, 557 P.2d 929, 135 Cal. Rptr. 345 (1976), cert. denied, 432 U.S. 907 (1977). The Supreme Court has left open the possibility that there is a fundamental right to a minimally adequate education. See Papasan v. Allain, 106 S. Ct. 2932, 2944 (1986).

118 See Restatement of Conflict of Laws $\S 377$ n.5 (1934).

110 Cf. Carey v. Brown, 447 U.S. 455 (1980) (invalidating statute that forbade picketing in residential areas because of its exemption for labor picketing).

120 See, e.g., Moore v. City of E. Cleveland, 431 U.S. 494 (1977) (invalidating zoning ordinance that prohibited certain categories of relatives from living together). 
Instead, the state could regulate the dockets of its courts by assigning subject matter jurisdiction in divorce actions only to the courts in a single county. These are, respectively, an explicit residence discrimination and a pure location discrimination with no apparent constitutional infirmities. ${ }^{121}$ If the state adopts both rules simultaneously, however, it creates an indirect residence discrimination that completely denies divorce to residents of every county but one. This result surely violates equal protection. ${ }^{122}$ Courts can go seriously astray by focusing on the components in isolation.

It might be suggested that heightened scrutiny should apply only to residence discriminations and never to pure location discriminations limiting the exercise of a fundamental right. For example, a statute forbidding first cousins to cohabit within urban areas would not be closely scrutinized so long as city dwellers who had the means to do so were free to cohabit incestuously in the country on weekends. I should admit that restricting fundamental rights equal protection to residence classes would not contradict most of the Supreme Court's precedents on territorial discrimination respecting fundamental rights; the reapportionment cases and even the Rodriguez case involved at least indirect residence discriminations. ${ }^{123}$ This restriction could give some needed content to the confusing motto that equal protection "relates to persons as such rather than areas."

Such a restriction might find support in theories of equal protection that limit the scope of the clause to combatting certain special kinds of classifications. For example, it could be argued that equal pro-

121 Except, perhaps, to the extent that this created an insuperable financial obstacle to the divorce of indigents. Cf. Boddie v. Connecticut, 401 U.S. 371 (1971) (invalidating on due process grounds a statute denying court access to indigents seeking marriage dissolution who could not afford court costs).

${ }_{122}$ See id. at 385-86 (Douglas, J., concurring); id. at 387-89 (Brennan, J, concurring). The contrary view, that the scheme is harmless because it merely forces the plaintiff to take up residence temporarily in the favored county, seems to be an unreasonable application of the already insensitive holding in Sosna v. Iowa, 419 U.S. 393 (1975) (upholding state durational residency requirement for those seeking divorce because the statute merely imposed a delay and did not exclude anyone from the state courts indefinitely).

${ }_{123}$ In Illinois State Bd. of Elections v. Socialist Workers Party, 440 U.S. 173 (1979), the Court invalidated a ballot access provision the effect of which was to require greater demonstrated support for a candidate's or party's entry into local elections than for entry into statewide elections. The Court expressly characterized this as a "geographic classification," $i d$. at 183 , and made no attempt to identify a disfavored class of residents. I do not think it is possible to frame this case as even an indirect residence discrimination. The Court's summary affirmance in Parker v. Levy, 411 U.S. 978 (1973), affg 346 F. Supp. 897 (E.D. La. 1972), invalidating as irrational a state revenue-sharing plan that distributed tax funds arbitrarily among parishes, is the clearest example of a pure location discrimination struck down by the Court, though it did not involve fundamental rights. 
tection should be concerned primarily with classifications turning on the characteristics of the person rather than those turning on the circumstances in which she seeks to exercise the right. ${ }^{124}$ A second, broader account would permit scrutiny of classifications based either on personal characteristics or on circumstances beyond the control of the actor, but not those based on her voluntary acts. ${ }^{125}$ Under either account, variations in the availability of a fundamental right in different locations would not qualify as an equal protection problem.

Both accounts are, however, subject to two major objections-they can be squared with neither reason nor precedent. First, aside from physical traits like race, gender, height, and age, "characteristics" cannot meaningfully be distinguished from "circumstances" and "acts." Residence, political affiliation, religious convictions, marital status, felon status, and often citizenship all result from voluntary interaction with external circumstances. ${ }^{128} \mathrm{~A}$ general rule of the form "Persons who do X may not thereafter do $\mathrm{Y}$ " is simply identical to a classificatory decision that "Persons with the characteristic of having done $\mathrm{X}$ may not do Y." ${ }^{127}$ In fact, the Court has rarely hesitated to scrutinize classifications based on "acts" or "circumstances." Innumerable rational basis equal protection cases have involved classification by acts, ${ }^{128}$ frequently by a chosen manner or line of business. ${ }^{129}$ Funda-

124 This appears to be the theory behind Justice Stewart's concurrence in Zablocki v. Redhail, 434 U.S. 374, 391 (1978). Justice Stewart also displayed great concern about identifying classes in his concurring opinion in Rodriguez, 411 U.S. at 62 (Stewart, J., concurring). This view may also inform Justice Stevens's concurring opinion in Glements v. Fashing, 457 U.S. 957, 973 (1982), that excused from even rational basis scrutiny variations in the qualifications for candidacy for different statewide offices, where "disparate treatment ... is entirely a function of the different offices [occupied]." Id. at 974-75. Justice Holmes once wrote an extraordinary opinion for the Court over Justice Harlan's dissent, holding that a discrimination between producers of domestic wines and liquor merchants not dealing in domestic wines was not subject to equal protection scrutiny because the alleged classes were not "classes naturally existing in the community," unlike farmers or raisers of livestock. See Cox v. Texas, 202 U.S. 446, 450 (1906). Professor Perry argues for an even narrower view than the one described in the text, namely that equal protection deals only with classification by morally irrelevant personal traits, which include neither voluntary acts nor physical or mental capabilities. See Perry, supra note 83, at 1065-67.

138 The description above is an attempt to fathom the meaning of Justice Stevens's statement that "general rules" regulating conduct cannot raise equal protection questions at all. See Jones v. Helms, 452 U.S. 412, 423-24 (1981); New York Transit Auth. v. Beazer, 440 U.S. 568, 587 (1979).

${ }^{128}$ On the voluntary character of residence in particular, see Martinez v. Bynum, 461 U.S. 321, 330-33 (1983); Rodriguez, 411 U.S. at 122 n.83 (Marshall, J., dissenting). But see Plyler v. Doe, 457 U.S. 202, 220 (1982) (finding that children of illegal aliens are not in the country voluntarily).

${ }^{127}$ An exception to this statement may be found in the ex post facto questions that might result from the timing of a rule's enactment.

${ }^{128}$ See, e.g., United States Dep't of Agric. v. Moreno, 413 U.S. 528, 534 (1973) 
mental rights equal protection cases have often involved classifications based on voluntary $\operatorname{acts}^{130}$ or the circumstances surrounding exercise of a right. ${ }^{131}$ Thus, generalities of equal protection theory present no obstacle to extending scrutiny of territorial discrimination beyond residence classifications.

Nor is tolerance of pure location discriminations required by principles unique to the doctrine of fundamental rights equal protection. The Supreme Court has made clear that not every classification that "affects" fundamental rights triggers heightened scrutiny under the equal protection clause. ${ }^{132}$ Selectively subsidizing some exercises of fundamental rights, by providing public schools, Medicaid for childbirth,

(unrelated persons living in one household); Eisenstadt v. Baird, 405 U.S. 438, 454-55 (1972) (remaining single); Lindsey v. Normet, 405 U.S. 56, 79 (1972) (tenants appealing from verdicts under forcible entry and wrongful detainer statute); Turner v. Fouche, 396 U.S. 346, 362 (1970) (failing to own freehold interest in property); Louisville Gas \& Elec. Co. v. Coleman, 277 U.S. 32, 38 (1928) (duration of mortgage determining tax exemption). This list includes only cases striking down the classifications and ignores the multitude where the classification withstood scrutiny. Of course, as we have seen, pure location discriminations also have been subjected to rationality review, though they generally survive this review in the Supreme Court. See, e.g., Salsburg v. Maryland, 346 U.S. 545, 550-51 (1954) (upholding statute making illegally seized evidence generally inadmissible in misdemeanor prosecutions, but admissible in prosecutions for certain gambling misdemeanors in one county).

129 See, e.g., Stewart Dry Goods Co. v. Lewis, 294 U.S. 550, 557-58 (1935) (sales tax graduated by sales volume); Concordia Fire Ins. Co. v. Illinois, 292 U.S. 535, 54849 (1934) (distinguishing between fire and casualty insurance); Smith v. Cahoon, 283 U.S. 553, 567 (1931) (exemption for carriers of agricultural goods); F.S. Royster Guano Co. v. Virginia, 253 U.S. 412, 414-15 (1920) (tax discrimination based on place of doing business); Atchison, T. \& S.F. Ry. v. Vosburg, 238 U.S. 56, 60 (1915) (discrimination between shippers and carriers); Connolly v. Union Sewer Pipe Co., 184 U.S. 540, 557 (1902) (discrimination between agriculture and other businesses). The foregoing are old cases finding the discriminations irrational. The modern cases tend to uphold the discriminations but continue to scrutinize them. See, e.g., Rice v. Norman Williams Co., 458 U.S. 654, 665 (1982) (distinguishing "designated" and "undesignated" alcoholic beverage importers); Minnesota v. Clover Leaf Creamery Co., 449 U.S. 456, 461-71 (1981) (distinguishing plastic and nonplastic milk containers); Barry v. Barchi, 443 U.S. 55, 67 (1979) (distinguishing harness and thoroughbred racing trainers); see also Railway Express Agency, Inc. v. New York, 336 U.S. 106, 114-15 (1949) (Jackson, J., concurring) (distinguishing vehicular advertising for hire and advertising of one's own business on one's own truck).

130 See, e.g., Kusper v. Pontikes, 414 U.S. 51 (1973) (prior party affiliation); Cipriano v. City of Houma, 395 U.S. 701 (1969) (ownership of real property); Carrington v. Rash, 380 U.S. 89 (1965) (membership in armed forces); Skinner v. Oklahoma ex rel Williamson, 316 U.S. 535 (1942) (larceny).

131 See, e.g., Illinois State Bd. of Elections v. Socialist Workers Party, 440 U.S. 173 (1979) (obtaining candidacy for local rather than statewide office); O'Brien v. Skinner, 414 U.S. 524 (1974) (convicted misdemeanants and pretrial detainees incarcerated in their county of residence denied opportunity to vote); Police Dep't v. Mosley, 408 U.S. 92 (1972) (picketing in nonlabor dispute).

182 See, e.g., Regan v. Taxation with Representation, 461 U.S. 540, 548-49 (1983) (finding that congressional decision to permit tax subsidies for lobbying by veterans' groups but not by others did not trigger strict scrutiny). 
or tax exemptions for veterans' groups, does not interfere with the exercise of fundamental rights by others at their own expense. ${ }^{133}$ Significant interference with the exercise of a fundamental right, however, will require close scrutiny of the classifications defining the interference. ${ }^{\mathbf{1 3 4}}$ The Court has not limited itself to some special category of classifications peculiarly relevant to the particular right. By coincidence, the Court's holdings in the free speech area have found equal protection violations only in two instances of blatant content discrimination. ${ }^{135}$ Nonetheless, the Court has formulated the implications of equal protection more broadly as forbidding discrimination among speakers or speech-related activities in a public forum. ${ }^{138}$ In the voting rights area, the Court has closely scrutinized all manner of qualifications erected as total barriers to the franchise. ${ }^{137}$ Where the state regulation keeps a candidate off the ballot, however, the Court has based its analysis on the voters' rights, not the candidate's, and has required a significant impact on the electorate before affording heightened scrutiny. ${ }^{138}$

Thus, it is the impact on fundamental rights that has led the Court to analyze closely a motley assortment of classifications not repugnant in themselves to the essence of the right in question. These include membership in the armed forces, ${ }^{139}$ failure to pay a filing fee, ${ }^{140}$ residence in a federal enclave, ${ }^{141}$ the distinction between state

${ }^{133}$ See id. at 548-50; see also Harris v. McRae, 448 U.S. 297, 316-18, 321-26 (1980) (holding that federal subsidy of other medical services but not abortions did not impinge on right to choose abortion and so was not subject to heightened scrutiny).

134 See Zablocki v. Redhail, 434 U.S. 374, 383 (1978).

13s See Carey v. Brown, 447 U.S. 455 (1980); Mosley, 408 U.S. at 92.

136 See, e.g., Perry Educ. Ass'n v. Perry Local Educators' Ass'n, 460 U.S. 37, 55 (1983); Carey, 447 U.S. at 460 . At the same time, it has held that a party validly excluded from a private forum cannot bootstrap her way in via the equal protection clause, because no fundamental right is being infringed. See Minnesota State Bd. v. Knight, 465 U.S. 271, 280-81 (1984); Perry, 460 U.S. at 54. Moreover, the Court has recently indicated that heightened equal protection scrutiny does not extend to discriminations affecting commercial speech. See Posadas de Puerto Rico Assoc. v. Tourism Co., 106 S. Gt. 2968, 2979 n.9 (1986) (citing Dunagin v. Gity of Oxford, 718 F.2d 738, 752-53 (5th Cir. 1983) (en banc), cert. denied, 467 U.S. 1259 (1984)).

${ }^{137}$ See, e.g., Dunn v. Blumstein, 405 U.S. 330 (1972) (durational residence requirement); Evans v. Cornman, 398 U.S. 419 (1970) (residence in federal enclave); Kramer v. Union Free School Dist., 395 U.S. 621 (1969) (lack of property ownership and not being a parent of a child attending school); Carrington v. Rash, 380 U.S. 89 (1965) (membership in armed forces).

138 See Anderson v. Celebrezze, 460 U.S. 780 (1983); Clements v. Fashing. 457 U.S. 957 (1982) (plurality opinion); Illinois State Bd. of Elections v. Socialist Workers Party, 440 U.S. 173 (1979); Buckley v. Valeo, 424 U.S. 1 (1976); Bullock v. Carter, 405 U.S. 134 (1972).

130 See Carrington, 380 U.S. at 89.

140 See Bullock, 405 U.S. at 134.

141 See Evans, 398 U.S. at 419. 
and city elections, ${ }^{142}$ and being a "resident having minor issue not in his custody and which he is under obligation to support by any court order or judgment."143 If these classifications all require heightened scrutiny, then nothing in the nature of fundamental rights equal protection precludes its application to pure location discriminations or other territorial discriminations.

Arbitrarily limiting equal protection analysis to residence discriminations would also produce grave practical injustice. Most distinctions based on geographical location will in fact fall most heavily on residents of the disfavored locality, particularly indigent residents, who cannot afford to travel for the purpose of exercising a fundamental right. Discriminations in the area of family privacy, for example, have their severest impact on residents of the disfavored locality, even if those traveling through may also be temporarily inconvenienced. Restrictions on freedom of speech would injure most seriously resident speakers and the resident audience, as well as those passing through or attempting to reach the resident audience. Strictly scrutinizing residence discriminations would do little to safeguard fundamental rights if nearly coextensive location discriminations escaped close examination.

The importance of closely scrutinizing pure location discriminations is supported by the exception that proves the rule: the de minimis geographical limitations tolerated as time, place and manner restrictions under the first amendment. "To be reasonable, time, place, and manner restrictions not only must serve significant state interests but also must leave open adequate alternative channels of communication."144 Opportunities foreclosed by a place restriction must be available "reasonably nearby."145 Here, ironically, the discrimination is the saving grace-picketing may be banned on the courthouse steps because it is permitted a block away. The key element of ample alternative channels for the exercise of the rights in question disappears when the regulation extends over a substantial area. Excluding a category of protected activ-

142 See Socialist Workers Party, 440 U.S. at 173.

163 Zablocki v. Redhail, 434 U.S. 374, 375 (1978).

14 Schad v. Borough of Mount Ephraim, 452 U.S. 61, 75-76 (1981); accord Heffron v. International Soc'y for Krishna Consciousness, 452 U.S. 640, 654 (1981).

145 Schad, 452 U.S. at 76 . I must confess that I wrote the text above before then Justice Rehnquist's opinion in City of Renton v. Playtime Theatres, 106 S. Ct. 925 (1986), which, if taken seriously as a statement of first amendment law, would effectively eviscerate the concepts of "time, place and manner," "content neutrality," and "narrow tailoring." It is reasonable to hope that the distortions introduced in that opinion will apply only to the category of "sexually explicit materials," particularly in view of the more conventional approach taken by the four-Justice plurality (three of whom silently concurred in Renton) in Pacific Gas \& Elec. Co. v. Public Útil. Comm'n, 106 S. Ct. 903 (1986), decided the same day. 
ity from a public library may be a minor restriction, but excluding it from an entire district severely infringes the rights of those affected, especially when the same conduct is permitted in the rest of the state.

\section{General Position-Random Intrastate Variations}

Once a classification is created affording different scope for the exercise of fundamental rights in different parts of the same state, the equal protection clause may be implicated. Suppose, for example, that the Commonwealth of Pennsylvania adopts a statute permitting marriage without parental consent at the age of sixteen west of the $78^{\circ} \mathrm{W}$ meridian, but forbidding such marriage until the age of twenty-three east of that line. ${ }^{146}$ The more stringent age limit is arguably constitutional when viewed in isolation, ${ }^{147}$ particularly given the inevitable arbitrariness of any age limit. ${ }^{148}$ But its juxtaposition with the more lax standard elsewhere in the same state creates a discrimination demanding heightened scrutiny. ${ }^{149}$ The different requirements may be justified by "local conditions," and the state should be afforded an opportunity to demonstrate their propriety. But separate age limits in, for example, urban and rural areas should be no more immune from heightened scrutiny than separate age limits for children of clerks and children of farmers.

Thus, geographical classifications affecting fundamental rights, like all others, should presumptively be subject to heightened scrutiny. As I shall soon be explaining at extraordinary length, however, discriminations whose contours run along political boundaries raise special questions that must be considered separately. ${ }^{150}$ For the present, then, the most we can state is the following general rule: when (1) a state imposes a geographical discrimination with respect to fundamental

146 Use of longitude to create territorial classifications is not as farfetched as it may sound. See, e.g., United States v. Tulare Lake Canal Co., 677 F.2d 713, 718-19 (9th Cir. 1982) (upholding statute applicable only west of $100^{\circ} \mathrm{W}$ meridian, which bisects six states), vacated as moot, 459 U.S. 1095 (1983).

147 See Zablocki, 434 U.S. at 399 (Powell, J., concurring).

148 See Oregon v. Mitchell, 400 U.S. 112, 294-95 (1970) (Stewart, J., concurring in part and dissenting in part); see also Louisville Gas \& Elec. Co. v. Coleman, 277 U.S. 32, 41 (1928) (Holmes, J., dissenting) (noting the inevitable arbitrariness of many types of legal distinctions).

${ }_{140}$ The precise standard of review applied in such cases is unclear. Compare Zablocki v. Redhail, 434 U.S. 374, 383 (1978) ("critical examination") with id. at 400 (Powell, J., concurring) ("fair and substantial relationship") and id. at 406 n.10 (Stevens, J., concurring) (level of scrutiny somewhere between "so strict that a holding of unconstitutionality is virtually foreordained". and one that is satisfied by "a rational expectation of occasional and random benefit").

${ }_{100}$ To foreshadow my conclusion once again, I believe that some, but not all, of these should escape heightened scrutiny. 
rights within its borders, and (2) it discriminates between substantial regions $^{151}$ the boundaries of which do not coincide with those of the state and its political subdivisions, and (3) the disparity is such that its imposition on nonsuspect classes that were not geographically defined would normally trigger heightened scrutiny, then the geographical discrimination should also be subjected to heightened scrutiny.

\section{First Special Position-Independent Action of Political Subdivisions}

The equal protection clause by its terms restricts the states themselves, not the executive or legislative officials of municipalities or other political subdivisions. Nonetheless, federal jurisprudence has always attributed municipal action to the parent state for purposes of the fourteenth amendment. ${ }^{152}$ The equal protection imperative has "reference to actions of the political body denominated a State, by whatever instruments or in whatever modes that action may be taken."15s Municipal corporations cannot hide behind their separate legal identity, for in federal contemplation they are merely state instrumentalities or agents, and "[t]he actions of local government are the actions of the State."154

When two different municipalities in the same state impose different restrictions on the exercise of fundamental rights within their respective borders, however, courts are not accustomed to scrutinizing this as a mode of state action. ${ }^{155}$ They do not attribute both ordinances back to the parent state and examine the resulting variation, even where a statute passed by the state explicitly imposing those same territorially limited restrictions would evoke rational basis or heightened scrutiny.

A lengthy detour is necessary to explore how municipal variations in the treatment of fundamental rights have come to escape equal pro-

151 The requirement that the area be substantial is a de minimis exception corresponding to the time, place and manner limitation in first amendment law. See Clark v. Community for Creative Non-Violence, 468 U.S. 288 (1984); Heffron v. International Soc'y for Krishna Consciousness, 452 U.S. 640 (1981).

${ }_{152}$ See, e.g., Home Tel. \& Tel. Co. v. City of Los Angeles, 227 U.S. 278, 294-96 (1913); Yick Wo v. Hopkins, 118 U.S. 356, 373 (1886). This identity had previously been recognized in cases involving the contract clause of the Constitution. See, e.g., Home Tel., 227 U.S. at 295; Murray v. Charleston, 96 U.S. 432, 448 (1878).

${ }^{15 s}$ Ex parte Virginia, 100 U.S. 339, 346-47 (1879); see also Yick Wo, 118 U.S. at 373-74 (stating that municipal authorities charged with the administration of ordinances represent the state).

134 Avery v. Midland County, 390 U.S. 474, 480 (1968).

185 Obviously, two municipalities are not necessary to create this situation. One home rule municipality and inaction by the rest of the state are enough. $C f$. Fort Smith Light \& Traction Co. v. Board of Improvement, 274 U.S. 387, 391 (1927) (equating state power to delegate authority to a municipality for local lawmaking with state power to enact law limited to that municipality). 
tection review. The superficially plausible explanation turns out to rest on a fallacy, and so a deeper explanation must be sought. It would be revolting to have no better reason for a rule of law than that so it was laid down in the time of Justice Field.

\section{a. The Single Decisionmaker Fallacy}

One possible explanation for this phenomenon is to give an "antiattribution" or "single decisionmaker" account of equal protection. Under such a theory, equal protection principles can be violated only when (1) actions are taken by a single government official or multimember decisionmaking body and (2) those actions simultaneously result in the imposition of different treatment on two or more classes. This account subsumes the vast majority of litigated equal protection cases, which involve either legislation expressly defining the class to which it applies or executive or judicial officers informally sorting individuals by their race or other criteria and discriminating accordingly. It covers the simplest model of an equal protection problem, the paradigm of explicit legislative classification. ${ }^{158}$ Under the "single decisionmaker" approach, the independent actions of two state officials will never be attributed back to the state for comparison. No equal protection question arises until we identify one person or body within the umbrella of the state affording favorable treatment to one group and unfavorable treatment to another.

This single decisionmaker approach is not a mere straw man engendered by diseased academic imagination. Justice Stevens provided a classic statement of this analysis in obiter dictum in his opinion for the Court in New York City Transit Authority v. Beazer. ${ }^{167}$ The Transit Authority had adopted a policy dictating that none of its employees could be methadone users, and Justice Stevens was prepared to give the back of his hand to Beazer's equal protection challenge:

The Equal Protection Clause of the Fourteenth Amendment provides that no State shall "deny to any person within its jurisdiction the equal protection of the laws." The Clause announces a fundamental principle: the State must govern impartially. General rules that apply evenhandedly to all persons within the jurisdiction unquestionably comply with this principle. Only when a governmental unit adopts a rule that has a special impact on less than all the persons sub-

156 See, e.g., Tussman \& tenBroek, supra note 27, at 346; Developments-Equal Protection, supra note 73 , at 1076-77.

167440 U.S. 568 (1979). 
ject to its jurisdiction does the question whether this principle is violated arise. ${ }^{188}$

The single decisionmaker theory has a superficial plausibility, and numerous statements of equal protection doctrine, if taken literally and out of context, suggest that it is well established.

One can without difficulty fashion arguments to support the single decisionmaker theory. First, the equal protection clause concerns itself with "classifications," and no classification occurs until some state actor divides her audience into two nonempty subsets. Second, the equal protection principle requires only similar treatment of similarly situated persons, and two individuals subject to two different decisionmakers are not similarly situated. Third, the equal protection clause forbids only intentional discrimination, and the prohibited intent to discriminate can be found only within a unified consciousness not distributed between separate actors addressing separate classes.

The weakness of these arguments should be self-evident. Equal protection concerns itself with inequality of treatment, regardless of whether an act of "classification" has occurred. ${ }^{169}$ From the beginning, the Supreme Court has recognized that the equal protection imperative deals with substance, not form-it addresses state action "by whatever instruments or in whatever modes that action may be taken."160 The fourteenth amendment is "a pledge of the protection of equal laws"161_not just facially neutral statutes, but a system of laws that in practical operation affords equality of rights to persons similarly situated. Statutory classifications are not examined in isolation, but rather are probed in the context of the state's legal system to determine their character. As Chief Justice Hughes wrote in Gregg Dyeing Co. v. Query:162

The question of constitutional validity is not to be determined by artificial standards. What is required is that state

${ }^{158}$ Id. at $587-88$ (dictum) (emphasis added). The language is dictum because the Court did not uphold the classification "without further inquiry," but analyzed its rationality at length.

168 See, e.g., Griffin v. Illinois, 351 U.S. 12, 17-18 (1956); id. at 34-36 (Harlan, $\mathrm{J}$., dissenting) (impact on the poor of generally applicable payment requirement for acquiring a trial transcript needed for appeal); Shelley v. Kraemer, 334 U.S. 1, 20-21 (1948) (judicial enforcement of private covenants based on race); Snowden v. Hughes, 321 U.S. 1, 8 (1944) (purposeful discrimination against a single individual); Cumberland Coal Co. v. Board of Revision, 284 U.S. 23, 28 (1931) (assessing property of differing value equally).

${ }_{160}$ Ex parte Virginia, 100 U.S. 339, 346-47 (1879).

161 Yick Wo v. Hopkins, 118 U.S. 356, 373-74 (1886).

182286 U.S. 472 (1932). 
action, whether through one agency or another, or through one enactment or more than one, shall be consistent with the restrictions of the Federal Constitution. There is no demand in that Constitution that the State shall put its requirements in any one statute. It may distribute them as it sees fit, if the result, taken in its totality, is within the State's constitutional power. ${ }^{163}$

The Supreme Court has continued to look to the totality of a state's relevant laws, rather than to single enactments, when evaluating claims of discrimination affecting fundamental rights or classes of persons. ${ }^{164}$ Recently, in American Motorists Insurance Co. $v$. Starnes, ${ }^{165}$ the Court provided an apt illustration of this principle by examining a state's venue statutes, its rules of civil procedure, and its informal court practices in order to decide whether a challenged venue statute subjected foreign corporations to discriminatory treatment.

The need for such fuller examination is evident. Did Justice Stevens really mean that once a state agency validly has been assigned authority over a given class, that agency's treatment of the class is free of all equal protection limitations? ${ }^{168}$ If so, then once a girls' high school has been lawfully made separate, ${ }^{167}$ its principal can make it unequal. A prison warden can deny all her inmates the right to vote. ${ }^{168}$ If a jury is convened to sentence only one defendant, it can impose the death penalty because she is black. ${ }^{168}$ The equal protection rights of

${ }^{183}$ Id. at 480 . The quotation in the text comes from the Court's discussion of discrimination in violation of the commerce clause. The Court also upheld the statute against an equal protection challenge, stating, "The same considerations, with respect to discrimination, apply to the claim that the statute in question violates the equal protection clause of the Fourteenth Amendment." Id. at 482.

164 See California Medical Ass'n v. Federal Election Comm'n, 453 U.S. 182, 200201 (1981); Michael M. v. Superior Court, 450 U.S. 464, $476-77$ (1981) (Stewart, J., concurring); id. at 483 (Blackmun, J., concurring); Williams v. Rhodes, 393 U.S. 23, 34 (1968).

${ }^{105} 425$ U.S. 637, 643-45 (1976).

${ }_{168}$ See New York Gity Transit Auth. v. Beazer, 440 U.S. 568, 587-88 (1979).

${ }^{167}$ Cf. Vorchheimer v. School Dist., 532 F.2d 880 (3d Cir. 1976) (public school system's regulations establishing gender-based admission requirements for two public high schools did not violate equal protection clause), aff'd by equally divided vote, 430 U.S. 703 (1977) (per curiam). But cf. Mississippi Univ. for Women v. Hogan, 458 U.S. 718, 720 n.1, 723-24 n.8 (1982) (finding that statutory exclusion of men from one of state's nursing schools unlawfully burdens males due to convenience of location and unique opportunity to get credit for working.).

168 See O'Brien v. Skinner, 414 U.S. 524 (1974) (violation of equal protection to deny convicted misdemeanants and pretrial detainees incarcerated in their county of residence opportunity to vote).

${ }^{189} C f$. Furman v. Georgia, 408 U.S. 238, 256-57 (1972) (Douglas, J., concurring) (expressing the opinion that discretionary death penalty statutes are unconstitutional because their effect is to single out minorities for punishment). I admit, though, 
juveniles vis-a-vis adults are implicated by statutory classifications, but not by the rules and practices of a juvenile court.

Within the area of fundamental rights, manipulating the jurisdiction of a government unit should not defeat equal protection. Imagine a state agency set up to regulate the activities of private corporations. The Deputy Director for For-Profit Corporations drafts a code of conduct for business corporations, which is then promulgated by the agency Head. The Deputy Director for Non-Profit Corporations drafts a code for nonprofits, similarly issued. If the latter Code forbids nonprofit corporations to engage in lobbying and door-to-door solicitation, while the For-Profit Code leaves businesses free to indulge in those activities, serious first amendment and equal protection questions arise. ${ }^{170}$ Yet this example is functionally indistinguishable from separate promulgation by the Deputy Directors pursuant to delegations from their Head or regulation by separate departments. To treat these situations differently would be the most stubborn exaltation of form over substance. "Let not thy left hand know what thy right hand doeth" is not a principle of constitutional law.

The single decisionmaker approach is not necessitated by the Supreme Court's recent emphasis on the role of discriminatory purpose in race and gender cases. ${ }^{\mathbf{1 7 1}}$ There, the event triggering close scrutiny is the employment of a suspect classification: the rule of Washington $v$. Davis ${ }^{172}$ is simply a test for detecting when facially neutral action is in fact based on a suspect classification. Where the suspect classification is explicitly employed, no further inquiry is needed. ${ }^{173}$ In fundamental rights cases, heightened scrutiny results not from the character of a classification but from the state's impingement on a fundamental right-as long as the restriction of a fundamental right is apparent, no

that this case can be analyzed in another way: racial discrimination might be detected where a decisionmaker, coincidentally having authority only over blacks, intentionally treats them differently than she would have treated whites. The comparison would then be with hypothetical decisions by the same decisionmaker, not with actual decisions by other decisionmakers, which would be relevant only as circumstantial evidence of likely motivation.

170 See Secretary of State v. Joseph H. Munson Co., 467 U.S. 947, 967 (1984); Regan v. Taxation with Representation, 461 U.S. 540, 552 (1983) (Blackmun, J., concurring); Village of Schaumburg v. Citizens for a Better Environment, 444 U.S. 620, 633, 639 (1980).

171 See, e.g., Personnel Adm'r v. Feeney, 442 U.S. 256, 279 (1979); Washington v. Davis, 426 U.S. 229, 241-42 (1976).

122426 U.S. 229 (1976).

173 See, e.g., Wayte v. United States, 105 S. Ct. 1524, 1531 n.10 (1985) ("A showing of discriminatory intent is not necessary when the equal protection claim is based on an overtly discriminatory classification."). 
other "intent" is required. ${ }^{174}$ Thus, reasoned examination of the single decisionmaker fallacy suggests that it is an ill-considered overgeneralization from the character of the usual equal protection case. ${ }^{175}$

174 See, e.g., Illinois State Bd. of Elections v. Socialist Workers Party, 440 U.S. 173, 183-87 (1979); Reynolds v. Sims, 377 U.S. 533, 565-68 (1964).

178 If there are readers who would prefer confirmation of this reasoning from the Supreme Court, such evidence is available. In its early twentieth century battles against discriminatory taxation, the Supreme Court frequently had occasion to articulate equal protection analysis inconsistent with the single decisionmaker approach. First, the Court juxtaposed state taxes levied against nonresidents in lieu of local taxation with local taxes levied by municipalities against their residents. See General American Tank Corp. v. Day, 270 U.S. 367 (1926). To avoid unconstitutional discrimination against nonresidents, the Court held that the rate of state tax must be substantially equivalent to the average of the varying local rates. See id. at 373-74. A devotee of the single decisionmaker approach might reinterpret these cases by pointing out that the state had jurisdiction to tax both residents and nonresidents but had only taxed nonresidents; there was thus a discrimination that could be justified as "compensating" for the taxes levied by third parties, the municipalities. The Court, however, denied that a discrimination existed. Rather, it perceived a "scheme of complementary tax statutes" and stated that there was no federal concern "with the particular method adopted by Louisiana of allocating the tax between the State and its political subdivisions." Id. at 37274.

The "single decisionmaker" theorist could not explain away another series of cases, in which the Court found merit in complaints of discrimination from a class of taxpayers subjected to heavier taxation by a state body whose jurisdiction extended only to that class. The jurisdiction of the limited agency in these cases was not geographically defined; rather the agency had jurisdiction to oversee the taxation of the railroads. Alternating between equal protection and state constitutional bases, the Supreme Court repeatedly rejected the idea that inequalities in assessment could be justified by the independence of the assessing bodies.

In Greene v. Louisville \& Interurban R.R., 244 U.S. 499 (1917), the plaintiff railroads argued that railroad property had been assessed by the state Board of Valuation and Assessment at $75 \%$ of value, while local assessors had assessed the property of individuals and other corporations at no more than $52 \%$ of value. The discrimination corresponded to a cleavage between the jurisdictions of the respective assessing bodies; the case "proceed[ed] on the theory that the Board of Valuation and Assessment treated all taxpayers alike over whom they had jurisdiction." Id. at 506. The Supreme Court held (for jurisdictional purposes) that the railroads' claim that collection of the tax as assessed "would violate the equal protection provision of the 14th Amendment, presents without question, a real and substantial controversy under the Constitution of the United States." Id. at 508. The Court did not resolve this issue, however, but held that the combined action of the assessing bodies violated the uniformity provisions of the state constitution:

Is discriminatory taxation, contravening the express requirements of the State Constitution, beyond redress in the courts of the United States, their jurisdiction being properly invoked, when the discrimination results from divergent action by different assessing boards whose assessments are not subject to any process of equalization established by the state, and where the diverse results are the outcome, not, indeed, of any express agreement among the officials concerned, but of intentional, systematic, and persistent undervaluation by one body of officials, presumably known to and ignored by the other body, so that in effect the two bodies act in concert? In our opinion, the answer must be in the negative.

Id. at 514. 


\section{b. The Special Status of Political Subdivisions}

The failure to extend any scrutiny whatsoever to territorial variations inhering in municipal ordinances is therefore an anomaly. The usual rule is that equal protection applies to "all action of the State denying equal protection of the laws; whatever the agency of the State taking the action, or whatever the guise in which it is taken."176 If territorially defined political subdivisions are to be treated differently than functionally defined arms of the state for equal protection purposes, there must be a reason.

An historical explanation is not hard to find-Missouri v. Lewis ${ }^{\mathbf{1 7 7}}$ itself placed territorial distinctions utterly beyond the realm of equal protection analysis for a generation. Yet even that sweeping decision rested on arguments. One may discern three ultimate bases for its absolute rule. First, a pseudo-textual argument: the equal protection clause applies only to classes of persons, not to the places at which those persons find themselves. Second, the ability of a state to govern its internal affairs depends on its flexibility in creating political subdivisions of its territory and regulating their local government. ${ }^{178}$ Third, the Constitution's tolerance for diversities in the law of different states implies a similar tolerance for variations in the law within a state. ${ }^{179}$

The third argument is plainly wrong, ${ }^{180}$ and the first has not sur-

Although Greene was decided on state law grounds, the Court adopted its holding as part of the federal law of discriminatory assessment violating the equal protection clause. In Southern Ry. Co. v. Watts, 260 U.S. 519 (1923), discussing an equal protection challenge based on an assessment structure just like that in Greene, Justice Brandeis stated:

The rule is well settled that a taxpayer, although assessed on not more than full value, may be unlawfully discriminated against by undervaluation of property of the same class, belonging to others. This may be true although the discrimination is practiced through the action of different officials. But, unless it is shown that the undervaluation was intentional and systematic, unequal assessment will not be held to violate the equality clause.

Id. at 526 (citations omitted). Again, in Baker v. Druesdow, 263 U.S. 137 (1923), he stated as an equal protection principle: "Where illegal discrimination was practiced, it is immaterial whether it was effected by a single assessing board or through the action of two independent boards." Id. at 142 (citing Greene and Southern Ry.). Thus, the Supreme Court too has insisted that the substance of state power, not the form of its distribution to different bodies, determines the legality of disparate treatment under the equal protection clause.

176 Cooper v. Aaron, 358 U.S. 1, 17 (1958); accord Ex parte Virginia, 100 U.S. 339,347 (1880).

177 U.S. 22 (1880).

178 See id. at $30-31$.

170 See id. at 31.

180 Variations between states escape equal protection analysis for a unique reason. See infra notes 220-23 and accompanying text. 
vived, ${ }^{181}$ but the second argument bears closer examination. The Lewis Court rejected the notion that the fourteenth amendment imposed totally centralized government on each state; instead, the states retained their right to create political subdivisions that would govern their own local affairs. The plaintiff had not really questioned this proposition, but he argued that the equal protection clause condemned disparities in the structures of the various subdivisions. If one county received direct appellate review of the decisions of its circuit court in the state supreme court in disbarment cases, then all other counties must. ${ }^{\mathbf{1 8 2}}$ His basic theory required total symmetry in the structuring of subdivisions-each subdivision must be a replica of every other, despite variations in population, land area, or other local conditions. ${ }^{183}$

The essence of the Lewis Court's decision was the desire to permit the states to tailor local regulation to local conditions. To emphasize the breadth of its holding, it hypothesized that the State of New York might adopt the civil law for New York City and the common law upstate. ${ }^{184}$ It also offered a more realistic example:

If a Mexican State should be acquired by treaty and added to an adjoining State, or part of a State, in the United States, and the two should be erected into a new State, it cannot be doubted that such new State might allow the Mexican laws and judicature to continue unchanged in the one portion, and the common law and its corresponding judicature in the other portion. . . . It would not be based on any respect of persons or classes, but on municipal considerations alone, and a regard to the welfare of all classes within the particular territory or jurisdiction. ${ }^{185}$

Implicit in this example is a dimension lacking in the New York City hypothetical. The continuation of Mexican law might well be justified not only by considerations of orderliness and efficiency but also by the wishes of the population affected. Some territorial variations may reflect a desire of the state to further its policies by taking into account local conditions, but others may be intended to effectuate local self-determination. Similarly, the creation of political subdivisions has been a vehicle for granting local control.

The Court's opinion in Lewis does not emphasize, or even implic-

181 See supra notes 26-67 and accompanying text.

182 See Lewis, 101 U.S. at 27.

183 Indeed, Bowman was a resident of St. Louis, which had been given a special court of appeals unavailable in most other counties. See id. at 25.

184 See id. at 31 .

185 Id. at 32. 
itly recognize, local self-determination. The issue was irrelevant to the case, because the variation being challenged was a structural one in the relations between county courts and the state supreme court. But there is a more important reason for the Court's avoidance of home rule rhetoric. The Court was emphasizing an opposing viewpoint-unlimited state control over political subdivisions-that was characteristic of federal constitutional law in its time, and that persists (though in a schizophrenic form) today. ${ }^{186}$

"Municipal corporations are mere instrumentalities of the State for the more convenient administration of local government. Their powers are such as the legislature may confer, and these may be enlarged, abridged, or entirely withdrawn at its pleasure." ${ }^{187}$ So far as the federal Constitution is concerned, municipal officials need not be elected, ${ }^{188}$ and the consent of the residents is not needed if the state chooses to restructure or abolish local government, or to enact local legislation itself. ${ }^{189}$ The Court has often denied that municipalities, when exercising power delegated by the state, can be recognized as "sovereign." "180

Despite this loudly proclaimed and effectively enforced doctrine of municipal transitoriness, the Supreme Court has also given constitutional significance to the traditional function of political subdivisions as vehicles for local self-determination. Cities and counties could be governed by state-appointed prefects, but in fact they are not.

[I]n providing for the governments of their cities, counties, towns, and districts, the States characteristically provide for representative government-for decisionmaking at the local

186 See Reynolds v. Sims, 377 U.S. 533, 575 (1964).

187 Meriwether v. Garrett, 102 U.S. 472, 511 (1880) (Field, Miller, \& Bradley, J.J.). This is a statement of Justice Bradley's position contemporary with his opinion for the Court in Lewis; it merely echoes similar expressions in, for example, Mount Pleasant v. Beckwith, 100 U.S. 514, 524-25 (1880); United States v. Railroad Co., 84 U.S. (17 Wall.) 322, 329 (1872); Maryland v. Baltimore \& O.R.R., 44 U.S. (3 How.) 534, 550 (1845), and is repeated in, for example, Reynolds, 377 U.S. at 575; Hunter v. Pittsburgh, 207 U.S. 161, 178-79 (1907); Williams v. Eggleston, 170 U.S. 304, 310 (1898). One unsurprising modern qualification should be mentioned-the state cannot abridge local government powers in a racially discriminatory fashion. See Washington v. Seattle School Dist. No. 1, 458 U.S. 457 (1982).

${ }^{188}$ See Sailors v. Board of Educ., 387 U.S. 105, 108 (1967); Fortson v. Morris, 385 U.S. 231, 234 (1966); Baltimore \& O.R.R., 44 U.S. at 550.

189 See Hunter, 207 U.S. at 178-79; Kies v. Lowery, 199 U.S. 233, 238-40 (1905); Rippey v. Texas, 193 U.S. 504, $509-10$ (1903); Railroad Co., 84 U.S. (17 Wall.) at 331-32; Baltimore E O.R.R., 44 U.S. at 550-51.

190 See, e.g., Community Communications Co. v. City of Boulder, 455 U.S. 40, 53-54 (1982); Waller v. Florida, 397 U.S. 387, 392 (1970); Reymolds, 377 U.S. at 575; United States v. Kagama, 118 U.S. 375, 379 (1886). 
level by representatives elected by the people. And, not infrequently, the delegation of power to local units is contained in constitutional provisions for local home rule which are immune from legislative interference. ${ }^{191}$

Both in fact and in law, the traditional description of municipalities as "mere instrumentalities of the State for the convenient administration of their affairs"182 is inaccurate. Since early colonial times, municipalities have served both as administrative subunits carrying out state policy and as independent structures for local policymaking reflecting the will of the smaller community. ${ }^{193}$ Their actions in the latter capacity have served the highest ends of political liberty; as de Tocqueville observed, "in the United States municipal liberty derives straight from the dogma of the sovereignty of the people."194 The state has the raw power to displace or to channel municipal lawmaking policies, or to abolish the municipalities altogether. But within the limits provided by state law, local governments are designed to further the policy preferences of the local electorate, not merely to divine the unexpressed will of the state legislature. ${ }^{195}$ They differ in this respect from administrative agencies, which must always justify their policy decisions, however tangentially, as effectuating goals chosen by the legislature. ${ }^{198}$ As a result, the Supreme Court has often permitted other constitutional interests to be outweighed by the role of local government in achieving self-determination. ${ }^{197}$ The Court has even characterized local

191 Avery v. Midland County, 390 U.S. 474, 481 (1968).

182 Mount Pleasant v. Beckwith, 100 U.S. 514, 529 (1880).

193 See, e.g., G. Haskins, Law and Authority In Early MassachusetTs $69-80$ (1960); 1 E. MCQuillen, The Law of Municipal Corporations $\$ \$ 1.10$ .16, 1.33-.38 (3d ed. 1971); A DE Tocqueville, Democracy in America 64-68 (G. Lawrence trans. 1969).

194 A. DE TocQueville, supra note 193, at 67; see also Frug, The City as a Legal Concept, 93 HARv. L. REv. 1057, 1068-72 (1980) (arguing that the desire to increase participatory democracy can be achieved best through decentralization of political power, possibly through city government).

198 See, e.g., Washington v. Seattle School Dist. No. 1, 458 U.S. 457, 478-82 (1982); Community Communications Co. v. Gity of Boulder, 455 U.S. 40, 54-56 (1982).

${ }_{196}$ See, e.g., Motor Vehicle Mfgs. Ass'n v. State Farm Mutual Ins. Co., 463 U.S. 29, 40-44 (1983); Immigration and Naturalization Serv. v. Chadha, 462 U.S. 919, 953 n.16 (1983).

197 See, e.g., Lockport v. Citizens for Community Action at the Local Level, 430 U.S. 259, 268-69 (1977) (upholding requirement that change in city government be approved by majorities both of city residents and noncity residents in light of "the wide discretion the states have in forming and allocating governmental tasks to local subdivisions, and the discrete interests that such local governmental units may have qua units); Hills v. Gautreaux, 425 U.S. 284, 300-06 (1976) (upholding a "metropolitan area remedy" against HUD for past housing discrimination but noting that it must be implemented "without preempting the power of local governments by undercutting the role 
populations as possessing the attribute of sovereignty, which they may exercise without procedural limitation through a referendum. ${ }^{198}$

If the distinction between political subdivisions and functionally defined arms of the state for equal protection purposes is to continue on any grounds other than historical accident, then it must be based on the local self-determination goal of political subdivisions. A centrally appointed city prefect would have no greater need for flexibility in adapting state policies to local conditions than a state agency would have in addressing particular industries or other segments of the population operationally defined. Indeed, the agency's need for flexibility has been the recognized driving force behind the distortion of constitutional separation-of-powers doctrines to accommodate the administrative process. ${ }^{199}$ But a municipal government pursuing locally chosen policies within a state-determined framework needs greater flexibility to prevent the local preferences of other municipalities from narrowing its own range of choices. Unlike administrative agencies, which ideally should accommodate one another in carrying out aspects of a legislative will, local governments are designed to pursue contrasting policies, each within its own sphere. These variations are not irrational, or enforced for their own sakes, but are the necessary result of maximizing local self-determination in a democratic society. Rational basis scrutiny would place only slight restrictions on this process, but strict scrutiny of variations in local choices respecting fundamental rights would make local self-determination in such contexts impossible.

Is local self-determination inconsistent with the guarantee against

of those governments in the federal housing assistance scheme"); Milliken v. Bradley, 418 U.S. 717,741 (1974) (holding that school district lines "may be bridged where there has been a constitutional violation calling for interdistrict relief" but they may not be "casually ignored or treated as a mere administrative convenience . . . contrary to the history of public education in our country"); Rodriguez, 411 U.S. 40-44 (finding that strict scrutiny is inappropriate in a case that challenges state and local judgments on how to raise and disburse taxes and how to administer educational policy); Abate v. Mundt, 403 U.S. 182, 185-87 (1971) (upholding a reapportionment plan that produced a deviation from equality of $11.9 \%$ in light of "the long tradition of overlapping functions and dual personnel" in the county government).

193 See Gordon v. Lance, 403 U.S. 1, 7 (1971); Hunter v. Erickson, 393 U.S. 385, 392 (1969). In Eastlake v. Forest City Enters., 426 U.S. 668, 676-79 (1976), the Court distinguished prior decisions invalidating on federal constitutional grounds delegations of legislative power to narrow segments of the population from the "reservation" of power to the entire population of a city. The distinction is surprising from a federal constitutional point of view; one would have thought that the sovereign body with power to reserve was the entire population of the state, and that restricting the referendum to city residents, however consistent with good political theory, was a delegation to a segment. (1965).

199 See, e.g., L. Jaffe, Judicial Control of Administrative ACtion 68-72 
denial of rights embodied in the notion of fundamental rights equal protection? If local populations could be viewed as a unit, or if their decisions always reflected unanimity, then we might argue that the variations in rights between political subdivisions were freely chosen by the inhabitants and therefore subjected them to no constitutionally cognizable disadvantage. But local populations are not homogeneous, and our traditions of municipal democracy permit a majority or a supermajority to impose its policy preferences on a dissenting minority. Thus, actual consent is not available as a defense to the charge of inequality. Still, local self-government, even without unanimity, avoids one great defect condemned by fundamental rights equal protection-the decision of a majority (or a ruling coalition) to afford itself greater scope for the exercise of a fundamental right than it allows to others. The legislature that permits labor picketing but not picketing to protest racial discrimination, or that erects unique obstacles to the marriage of indigents with child support obligations, or that denies the franchise to residents of a particular enclave within the state, has withheld from others the exercise of rights it guards jealously for itself. In contrast, when local self-determination leads to a stricter rule than obtains in other jurisdictions, the members of the local majority have bound the community to a self-denial that they too must observe. ${ }^{200}$

This factor is not in and of itself sufficient to demonstrate that local self-government is inoffensive to fundamental rights equal protection. Even if the local majority cannot be considered as denying the dissenters any advantage that it preserves for itself, the state majority might be thought of as infringing the dissenters' rights by subjecting them to the decisions of this particular local electorate. After all, the boundaries of political subdivisions are determined by a combination of state and local legislative decisions, and membership in the local community of the governed is involuntary. Individuals can choose membership in another subdivision only by change of residence, an action with extraordinary costs, and one whose practical availability to different individuals varies with their circumstances. ${ }^{201}$ And ultimately, no one can

200 It is true that the majority may be bound only in a technical sense, because they have adopted a limitation on a right that does not affect the situations in which they need or desire to exercise it, but this problem can be dealt with by fundamental rights equal protection analysis of the classification imposed on the exercise of the right within the community and does not require comparison with the standards prevailing outside the community.

${ }^{201}$ In his well-known article, Charles Tiebout suggested a simple model of local government services in which the different packages of public goods offered by different municipalities were fixed, and individuals exercised their preferences by moving to the municipality whose package pleased them the most. See Tiebout, A Pure Theory of Local Public Expenditures, 64 J. Pol. Econ. 416 (1956). Tiebout recognized that this 
avoid assignment to one of the state's political subdivisions except by leaving the state altogether. Thus, when the state confers legislative authority with respect to fundamental rights on local governmental units, it is assigning individuals to groups and instructing those individuals that the legal obligations defining the scope of their rights will be determined by the preferences of a majority of the group to which they are assigned. Such assignments unquestionably raise equal protection concerns. If the state were to define an individual's fundamental rights by the expressed preferences of her race, her economic class, her profession, her age cohort, or those sharing her level of educational attainment (to give both otherwise suspect and otherwise nonsuspect examples), serious equal protection objections would arise. If it is offensive to equal protection for the state to say, "You are a carpenter, and it is appropriate for the contours of your right to sexual privacy to be determined by a majority of the carpenters, while the rights of actors will be determined by a majority of the actors," then it might be equally offensive to say, "You are a resident of Pittsburgh, and it is appropriate for the contours of your right to sexual privacy to be determined by a majority of the Pittsburghers, while the rights of Philadelphians will be determined by the majority in Philadelphia."

It is not difficult to imagine a society in which value judgments were not made at a local level by public institutions. To the extent that local variations were desired, individuals might be free to band together voluntarily into private associations, reaching decisions that would influence conduct in the community through social pressure, perhaps even without recourse to the aid of state contract and property law. Those who sought to steer clear of entanglement with the private associations might be legally entitled to do so. In such a society, for the state to bind residents to the collective decisions of their neighbors might be highly offensive to principles of equal protection.

But this does not describe our society. Throughout our history we have relied on territorially defined local governments with coercive state powers as a vehicle for diversified popular self-determination. If an appeal to the history of our institutions has any role to play in the elaboration of constitutional principles, then local self-determination through

model overlooked significant moving costs, see id. at 422-23, and he eliminated the pressures generated by the unequal distribution of employment opportunities by assuming a population of coupon-clippers. See id. at 419. Subsequent economic literature has emphasized these divergences between Tiebout's model and reality, see, e.g., Inman \& Rubinfeld, The Judicial Pursuit of Local Fiscal Equity, 92 HaRv. L. REv. 1662, 1685 \& $n .48$ (1979), as well as the barriers to mobility caused by racial discrimination and class-exclusionary zoning, see id., and community ties. See Dunn, Measuring the Value of Community, 6 J. URB. EcoN. 371 (1979). 
political subdivisions has at least some claim to distinctive treatment that would save it from condemnation by equal protection.

It should be noted that, from the standpoint of the affected individual, allowing local self-determination does not always result in a diminution of rights. If we were to require uniform statewide policymaking regarding fundamental rights, a local majority favoring greater exercise of constitutional rights could no longer act on that preference within its local sphere unless it could muster a statewide majority. Thus, in absolute terms, preserving local government autonomy expands the spectrum of opportunities for exercise of constitutional rights within a state. It does not contract the spectrum, for by definition, equal protection analysis only guarantees statewide availability of opportunities already provided somewhere within the state. ${ }^{202}$

Moreover, the very arbitrariness of geographical boundaries makes them a less threatening basis for allocating powers of self-determination. States allocate this authority geographically for obvious reasons of administrability and common interest, as well as to give voice to the familiar feelings of community. ${ }^{203}$ Gerrymanders and exclusionary tactics are unfortunately all too common and can be effective in the short term. ${ }^{204}$ But absent such subterfuge, a state that carves up its territory into subdivisions, each given the same opportunities for the exercise of governmental power, has distributed in an impersonal and impartial fashion the authority to define rights. In these circumstances, the danger is at a minimum that assignment to a political subdivision would constitute a sacrifice of an individual's fundamental rights because of disfavor, disrespect, or inattention.

Thus, there are strong practical and historical reasons for permitting variations in fundamental rights to arise through local self-determination, and there are reasons for believing that these variations do not offend the underlying purposes of fundamental rights equal protec-

${ }^{202}$ The argument above presupposes a static model and does not consider whether the existence of variations within the state would over time lead to a further expansion or to a contraction of the range of opportunities afforded.

${ }^{203}$ I do not wish, however, to argue that constitutional toleration for municipal self-determination is compelled by claims based on a moral or philosophical conception of Community in a strong sense. In modern American society, such genuine Communities are not generally coextensive with municipalities-a Community may spill over political boundaries, or one city may contain many separate Communities, confined within neighborhoods, or within social strata, or otherwise nonspatially defined. See, e.g., T. Bender, Community and Social Change in America 148-49 (1978); Frug, supra note 194, at 1061-62. The correlation between political subdivision and Community is too weak to carry the argument.

${ }^{204}$ Even in Lewis, the Supreme Court made the suggestion, brought to fruition in Gomillion v. Lightfoot, that geographical distinctions demonstrably motivated by prejudice would not be treated as deferentially. See Lewis, 101 U.S. at 32. 
tion. We must next consider whether local self-determination can be accommodated within fundamental rights equal protection methodology.

\section{c. Accommodating Self-Determination and Equal Protection}

If failure to scrutinize intercity variations in substantive law has. some justification in terms of self-determination, the question remains how this justification can be evaluated through equal protection doctrine. First, should these variations be exempt from rational basis scrutiny as they seemingly have been, or is it merely that they always withstand the scrutiny? This question is almost entirely academic. ${ }^{205}$ At a hazard, I would suggest that minimal rationality is too lax a standard to waive, and too slight an interference to cause concern, so that nominally subjecting these variations to a rationality test is preferable. ${ }^{208}$ They will, however, virtually always pass. The differences result from differing local policy choices and reflect the operation of grassroots democracy. If each choice is in itself rational enough to withstand due process scrutiny in isolation, then reasonable communities can disagree, and their juxtaposition is rational. ${ }^{207}$

Heightened scrutiny makes the distinction a real one. The mere fact of a difference in the policy preferences of the majority in two communities is surely not a factor compelling enough to justify differences in the standards for exercise of a fundamental right in those communities. If a majority of each race voted in favor of racial separation, this would not itself be compelling enough to justify its implementation

203 See Gunther, Foreword: In Search of Evolving Doctrine on a Changing Court: A Model for a Newer Equal Protection, 86 HARv. L. REV. 1, 8 (1972) ("minimal scrutiny in theory and virtually none in fact").

${ }^{300}$ Making the equal protection claim cognizable but frivolous rather than ruling it out of bounds would not be a significant spur to litigation. Courts are quite capable of suppressing frivolous equal protection claims. See, e.g, Andrews v. Maher, 525 F.2d $113,116-18$ (2d Cir. 1975) (dismissing as insubstantial a claim that a state violated the equal protection clause by providing governmental offices only in limited number of locations and then refusing to reimburse welfare recipients for expenses incurred in traveling to those offices).

207 There may be anomalous exceptions. In rare instances, the pattern of laws in outside communities may render a local ordinance in City $X$ so ineffectual or so impossible of compliance that it would constitute a mere arbitrary oppression. $C f$. Bibb v. Navajo Freight Lines, 359 U.S. 520 (1959) (invalidating as an unreasonable burden on interstate commerce a state statute that required trucks and trailers operating on state highways to be equipped with specified type of mudguard that was illegal in one state and different from those permitted in $\mathbf{4 5}$ other states). In that case, the disparity could be condemned as irrational; the question remains academic, however, because even the rational basis test would not require a court to blind itself to the existence of conflicting laws in neighboring communities if City X's ordinance were challenged in isolation under the due process or equal protection clauses. 
under strict scrutiny. ${ }^{208}$ If a majority of each sex voted to bar women from certain professions, that in itself would not be sufficient to overcome intermediate scrutiny. ${ }^{209}$ The desire of a majority of any group to disenfranchise the group would not be enough to overcome the group's right to equal participation in voting. ${ }^{210}$ Effectuating majority preference is, in the abstract, an important goal in a democracy and may justify variations in government structure to facilitate it. ${ }^{211}$ When weighed against individual violations of constitutional rights, however, this abstract interest is not compelling in the context of nonterritorial classifications and therefore should not be treated as compelling in the context of territorial classifications. Mischaracterizing the nature of the interest to avoid an undeniable anomaly is not the solution. "Open debate of the bases for the Court's action is essential to the rationality and consistency of [its] decisionmaking process." 212

Moreover, it would be very difficult to say in any particular instance that a state's acceptance of local decisionmaking on a matter of fundamental rights was narrowly tailored to achieve the alleged interest in self-determination. ${ }^{213}$ Imagine, for example, a city ordinance prohib-

${ }^{208}$ Cf. Wygant v. Jackson Bd. of Educ., 106 S. Ct. 1842, 1847, 1850 n.8 (1986) (plurality opinion) (stating that preferential layoff schemes based on race could not affect the rights of workers who were injured by the plan, even if a majority of the union members of both races approved the plan); Regents of the Univ. of Cal. v. Bakke, 438 U.S. 265, 307 (1978) (opinion of Powell, J.) (stating that desire of majority to favor minority, without more, is not compelling interest); Castaneda v. Partida, 430 U.S. 482, 499-500 (1977) (finding that control of government by local Hispanic majority would not immunize discrimination against Hispanics in the grand jury selection process); Green v. County School Bd., 391 U.S. 430 (1968) (rejecting "freedom of choice" desegregation plan).

${ }^{209}$ Cf. Mississippi Univ. for Women v. Hogan, 458 U.S. 718, 727-30 (1982) (stating that legislature's desire to benefit women, without showing of specific need to redress discrimination, did not justify gender discrimination disfavoring men).

210 See Lucas v. Forty-Fourth Colo. Gen. Assembly, 377 U.S. 713, 731-32, 73637 (1964) (approval by a majority of the voters in every county did not validate malapportionment).

${ }_{211}$ Cases upholding minor deviations from the one-person, one-vote rule to accommodate local government structure analyze them as legitimate exceptions to the rule of strict scrutiny, not as applications of the rule. See, e.g., Brown v. Thomson, 462 U.S. 835, 842-46 (1983); Mahan v. Howell, 410 U.S. 315, 325-328 (1973). But see Abate v. Mundt, 403 U.S. 182, 185 (1971) (stating that state interests offered as justifications for deviations from the one-person, one-vote rule must be "carefully scrutinized").

${ }^{212}$ Rodriguez, 411 U.S. at 110 (Marshall, J., dissenting).

213 For an unusually careful statement of the standard of review from Justice Powell, see Wygant v. Jackson Bd. of Educ., 106 S.Ct. 1842, 1850 n.6 (1986):

The term "narrowly tailored," so frequently used in our cases, has acquired a secondary meaning. More specifically, as commentators have indicated, the term may be used to require consideration whether lawful alternative and less restrictive means could have been used. Or, as Professor Ely has noted, the classification at issue must "fit" with greater precision than any alternative means. 
iting the sale or rental of erotic though nonpornographic video cassettes to persons under the age of twenty-one. Adoption of such an ordinance in one city, while the video rental market goes unregulated in the rest of the state, might be defensible as permitting each self-governing community to strike for itself a balance between freedom to disseminate cinematic works and protection of the morals of the young. But suppose further that the state legislature has already enacted a variety of statewide measures aimed at regulating erotica and protecting the young. The state has a statute prohibiting operation of adult bookstores or movie theatres within 1000 feet of a school, and a basic obscenity statute. In a compromise with the cable television industry, the state also has enacted legislation forbidding the broadcast of X-rated movies over cable networks except between the hours of 11 p.m. and 6 a.m., but authorizing such broadcast during those hours. Within that context, it cannot seriously be maintained that the resulting territorial variation in the right to rent video cassettes is narrowly tailored to achieve the state's "compelling interest" in deferring to local preferences regarding the balance between first amendment and youth-protection goals. To accept that argument in the face of the state's haphazardly asserted interest would deprive strict scrutiny of all its content.

If accommodating the preferences of local majorities is not necessary to achieve a "compelling interest" and the single decisionmaker theory provides no avenue of escape, then a court faced with local ordinances variably constricting fundamental rights has two choices. First, it may apply heightened scrutiny, with the knowledge that this will frequently remove regulation of fundamental rights from the sphere of local authority. This might not be an undesirable result. It would ensure that most restrictions of fundamental rights are made only at the level of highest legislative authority, the state legislature, and as I will argue later, on a statewide basis. ${ }^{214}$ Alternatively, the court may recognize the need to modify its analysis of the equal protection concerns arising from intercity variations in substantive law. It may excuse the variation from strict scrutiny, not because the localities have a compelling need for autonomy in the particular case that outweighs the injury to equal protection values, but rather because, as a general matter, the legitimate interest of the people in self-determination at the local level justifies a limited exception to equal protection analysis.

Thus, what I am proposing is that intrastate variations in the

(quoting Ely, The Constitutionality of Reverse Racial Discrimination, 41 U. CHI. L. REv. 723, 727 n.26 (1974)).

${ }_{214}$ See Sandalow, The Limits of Municipal Power Under Home Rule: A Role for the Courts, 48 MinN. L. REv. 643, 708-21 (1964). 
scope of fundamental rights that result from the independent decisions of self-governing political subdivisions should be excused from heightened scrutiny and subjected only to the rational basis test. They should be so excused because they are justified by their contribution to the goal of local self-determination, though not in a way that would withstand heightened scrutiny under the equal protection clause. ${ }^{215}$ An exception to the scrutiny that would otherwise be applied is therefore required when geographical classifications affect fundamental rights.

This modification of equal protection methodology is neither extreme nor unprecedented. In practice, the same result is achieved universally today by the unquestioned failure of the courts to analyze any variation between the independent actions of two municipalities in the same state under the rubric of equal protection. As a matter of theory, similar modifications of equal protection have been made in other contexts to further interests in self-determination. First, the Supreme Court has made numerous exceptions to strict scrutiny of departures from the "one-person, one-vote" rule in voting rights cases-exceptions intended to accommodate local government. ${ }^{216}$ Second, the Supreme Court has treated the requirement that a voter be a bona fide resident of the political subdivision as "exempt from strict judicial scrutiny," in order to "preserve the basic conception of a political community."217 Third, the Court has asserted interests in local government autonomy as a justification for restricting remedies in cases of racial discrimination by state and local officials. ${ }^{218}$ Lastly, the Court has already adopted a "dual standard" of equal protection in cases of state discrimination against aliens, in order to facilitate "the community's process of political self-definition" ${ }^{\text {219 }}$ as a preliminary step toward state and municipal self-government.

215 The use of the terms "excuse" and "justification" in this context does not refer to notions of excuse and justification traditionally employed in the field of criminal law. 226 See, e.g., Brown v. Thomson, 462 U.S. 835, 842-43 (1983); Mahan v. Howell, 410 U.S. $315,325-28$ (1973).

${ }^{217}$ Holt Civic Club v. City of Tuscaloosa, 439 U.S. 60, 82 (1978) (Brennan, J., dissenting). Then Justice Rehnquist's opinion of the Court in Holt is in accord with this exception, but does not vouchsafe a rational explanation for its action. See id. at 66-70. Justice Marshall had suggested in dictum in Dunn v. Blumstein, 405 U.S. 330, 343-44 (1972), that bona fide residence requirements might be "necessary" and therefore might withstand strict scrutiny, but he was not contemplating the fact situation of Holt, which can only be characterized as applying an exception.

${ }_{218}$ See, e.g., Milliken v. Bradley, 418 U.S. 717, 741, 744 (1974).

210 Cabell v. Chavez-Salido, 454 U.S. 432, $439-40$ (1982); see also Note, A Dual Standard for State Discrimination Against Aliens, 92 HARV. L. REv. 1516 (1979) (describing the Supreme Court's dual equal protection standard for reviewing classifications that disadvantage aliens, while attempting to resolve inconsistencies in the standard). 
Accommodating local preferences by excusing independent local decisions from heightened scrutiny would similarly further constitutional values of political self-determination. The resulting inequalities cannot be denied. The exception would uphold all-but-irrational territorial variations in the scope of fundamental rights, so long as each local law itself withstood review. But the trade-off between uniformity and autonomy is inevitable, and in a nation historically committed to self-government from the town meeting on up, the necessary loss of territorial uniformity is not too high a price to pay for making local self-determination possible. Thus, the traditional failure to scrutinize closely varying municipal ordinances within the same state can be justified in modern terms and should continue.

\section{Second Special Position-Interstate Variations}

We should next consider situations in which state action causes fundamental rights to vary from state to state. To begin with the obvious, the equal protection clause of the fourteenth amendment does not require that a state restrict a fundamental right within its borders only in those situations where all the other states limit the right within their own borders. A variation in the treatment of furidamental rights between neighboring states triggers no standard of review, not even the most minimal test of rationality. ${ }^{220}$ A textual argument for denying review rests on the language of the equal protection clause itself: "Nor shall any State ... deny to any person within its jurisdiction the equal protection of the laws."221 The clause addresses only actions taken by an individual state, not differences between states. ${ }^{222}$ The elements of our constitutional history support this literal reading. The independent sovereignty of the states over matters within their respective jurisdictions has been one of the key principles of federalism. ${ }^{223}$ Thus, inter-

220 For a visionary plea that they should, at least in the voting rights area, see Miller and Bowman, Toward an Interstate Standard of Equal Protection of the Laws: A Speculative Essay, 1981 B.Y.U. L. REv. 275. To adopt that approach would essentially be to abolish the authority of the states to legislate at all in ways that affect fundamental rights, except to help determine the most tolerant common denominator.

221 U.S. CONST. art. XIV, $\$ 1$.

${ }_{222}$ See Gurley v. Rhoden, 421 U.S. 200, 211-12 (1975) (characterizing a contrary claim as patently frivolous).

${ }^{22 s}$ See, e.g., Heath v. Alabama, 106 S. Ct. 433, $437-40$ (1985); Edgar v. MITE Corp., 457 U.S. 624, 642-43 (1982); Nevada v. Hall, 440 U.S. 410, 423-24 (1979); Pennoyer v. Neff, 95 U.S. 714, 722 (1878); see also Braybrooke, Can Democracy Be Combined With Federalism or With Liberalism?, in LIBERAL Democracy: Nomos XXV 109, 111 (1983) (stating that existence of two or more states in federal union implies that "local" issues in each state are withdrawn from agenda of every other state). 
state variations resulting from the juxtaposition of the independent actions of two sister states pose no equal protection problems.

Is this the price we pay for federalism, or is it one of the great virtues of federalism? The glass is either half empty or half full, depending on the viewer's standpoint. Federalism permits the majority in each state to choose how far above the constitutional minimum the exercise of fundamental rights will extend locally. Some states will afford more freedom than the mean; others will afford less than the mean. All states, in making these choices, will be exercising the independently valued freedom of local self-determination within their respective spheres.

Uncertainties in the field of conflict of laws, however, make these spheres difficult to delineate and thereby jeopardize the benefits of independent choice. Fundamental rights equal protection could serve to aggravate the difficulties. The act of choice of law transforms the pristine independence of statute making by two states into discrimination by the courts of one of them. Whenever a state exercises some discretion in applying its own or another state's law to cases deemed appropriate, it becomes subject to equal protection claims. ${ }^{224}$

\section{a. The Choice of Law Problem}

In an oversimplified model of interstate variations, each state decides for itself the permissible range for the exercise of fundamental rights within its borders. In reality, transactions tend to spill across state borders, and often several states have plausible interests in assigning legal consequences to a harmful event. For example, a television program produced in California and broadcast from Delaware to Pennsylvania, Maryland, and New Jersey, might defame a citizen of Illinois. Earlier in this century, the Supreme Court incorporated rigid common law choice of law rules into federal constitutional law in order to police state assertions of prescriptive jurisdiction. ${ }^{228}$ The traditional choice of law framework has been largely discredited, however, and replaced by a cacophony of mutually incompatible methodologies. ${ }^{228}$ The Court has wisely refrained from singling out any of these methodolo-

224 See Currie \& Schreter, Unconstitutional Discrimination in the Conflict of Laws: Privileges and Immunities, 69 YALE L.J. 1323, 1323-24 (1960).

228 See, e.g., Home Ins. Co. v. Dick, 281 U.S. 397 (1930); New York Life Ins. Co. v. Dodge, 246 U.S. 357 (1918); $c f$. Mutual Life Ins. Co. v. Liebing, 259 U.S. 209, 214 (1922) ("[T]he Constitution and the first principles of legal thinking allow the law of the place where a contract is made to determine the validity and the consequences of the act."). 1984).

${ }^{226}$ See J. Martin, Conflict of Laws: Cases and Materials 166-67 (2d ed. 
gies as constitutionally required. ${ }^{227}$ As a result, the Constitution, by means of the due process and full faith and credit clauses, now places only minimal obstacles to the application of its own law by a state that arguably has some relation to a transaction. ${ }^{228}$

When do state choice of law decisions raise equal protection problems? From a forum state's point of view, we can distinguish three categories of cases: (1) wholly foreign cases, in which the forum state has so little connection to the dispute that the due process or the full faith and credit clause forbids the state to apply its own law; ${ }^{228}$ (2) multistate cases, in which those clauses permit both the forum and one or more other states to apply their laws,; ${ }^{230}$ and (3) wholly domestic cases, in which the due process or full faith and credit clause forbids any state but the forum to apply its own law. ${ }^{231}$ Conflicts experts disagree as to how large these categories should be, and as to which cases should fall within them. The factors that will, under various theories, determine the category to which a case belongs include the residences of the various parties, the locations of various acts constituting the transactions, the situs of items of property, and the locations where various impacts of the transactions are felt. Adopting a rigid set of choice of law rules as a matter of constitutional law would increase the size of the wholly foreign and wholly domestic categories at the expense of the multistate category. Under current law, however, this intermediate category is enormous. ${ }^{232}$

A state's refusal to apply its own law to cases within the first, wholly foreign category should never create an equal protection violation. The same is true of a decision to apply its own law in the third, wholly domestic category. This follows from the more general claim that classifications forced upon state action in a given context by the Constitution itself are ipso facto justified under the equal protection clause. ${ }^{233}$ Where a clause of the Constitution, expressly or by judicial

${ }^{227}$ See, e.g., Phillips Petroleum Co. v. Shutts, 105 S. Ct. 2965, 2986 (1985) (Stevens, J., concurring and dissenting); Allstate Ins. Co. v. Hague, 449 U.S. 302, 307 (1981) (plurality opinion); Jackson, Full Faith and Credit-The Lawyer's Clause of the Constitution, 45 Colum. L. REv. 1, 26-27 (1945).

${ }_{228}$ See J. MARTIN, supra note 226, at 338-39.

229 See, e.g., Phillips Petroleum Co., 105 S. Ct. at 2977-81.

230 See, e.g., Allstate Ins., 449 U.S. at 313-19. I will use the term "multistate" in an idiosyncratic way, to describe cases where choice between forum law and foreign law is possible, excluding those cases where the forum state could not apply its own law but rather must choose among the laws of several foreign states.

${ }^{231}$ Conccivably, there is a narrower category of cases in which the due process clause affirmatively requires the state to apply its own law. See id. at 327 (Stevens, J., concurring).

${ }_{232}$ See J. MARTin, supra note 226, at 166-67, 338-41.

2ss This claim is not uncontroversial. It implies, for example, that the twenty- 
construction, singles out the distinction between two government actions as so significant that the Constitution permits one action and proscribes the other, the equal protection clause should not be used to convert the permitted action into a forbidden one by arguing that there is no constitutionally sufficient difference between them. If there were no sufficient difference, then the permitted action ought never to have been regarded as tolerable in the first place. Absent clear indication that the equal protection clause was intended to repeal another constitutional provision, boundaries of government power drawn by the Constitution itself should not be regarded as offensive to constitutional ideals of equality. Thus, the few geographical discriminations required by the full faith and credit and due process clauses should never trigger heightened equal protection scrutiny, regardless of their impact on a fundamental right.

This leaves an enormous range of multistate cases, in which a state will have a sufficient interest that it could validly exercise prescriptive jurisdiction, but in which other states have similar or even greater interest. In many of these instances, the interest of the sister state in governing the transaction will be demonstrably greater than that of the forum state. Nonetheless, neither constitutional doctrine nor many modern choice of law theories would disable the forum from applying its own law in such circumstances. For example, in the view of some conflicts scholars, the forum state always has an interest in applying its rules of liability to an out-of-state defendant who has injured a forum state resident in the defendant's home state. ${ }^{234}$ Under this view, if Alabama had very strict libel laws, it might justifiably desire to impose liability for defamation of one of its residents by a New York newspaper of limited circulation only in New York, even if the people of New York had decided to maximize the freedom of the press in their state by abolishing the tort of defamation. ${ }^{235}$ Instead, however, a state

sixth amendment's conferral of the right to vote on 18-year-olds forestalls the argument that denying the vote to 17 -year-olds violates equal protection and that the fourteenth amendment's conferral of citizenship on children born in the United States forestalls the argument that denying citizenship to children born abroad to American citizens would violate equal protection. For a contrasting view, see Eisenstadt v. Baird, 405 U.S. 438, 452-53 (1972), which appears to say that even assuming that the constitutional right to use contraception recognized in Griswold v. Connecticut, 381 U.S. 479 (1965), extends only to married persons, it would be unconstitutionally irrational for a state to forbid such use by unmarried persons while permitting its use by married persons. Cf. Memorial Hosp. v. Maricopa County, 415 U.S. 250, 256 n.9 (1974) ("It would seem inconsistent to argue that the [county's] residence requirement should be construed to bar longtime [state] residents, even if unconstitutional as applied to persons migrating into Maricopa County from outside the state.").

2s4 See, e.g., J. MARTin, supra note 226, at 220-23.

238 How strict libel laws can be is an issue currently in flux. After Gertz v. Robert 
may choose to defer to the law of a sister state. Alabama might conclude that imposing its tort sanctions on the newspaper would too greatly frustrate New York's legitimate local policy and thus might decline to extend its laws so far. If not compelled by the full faith and credit or due process clauses, this exercise of comity would represent a voluntary accommodation to the coequal sovereignty of a sister state in a federal system. ${ }^{236}$ This comity is an important virtue in our constitutional scheme. ${ }^{23 z}$ The fact that the Supreme Court has proved unable to provide useful guidance through the letter of the full faith and credit clause should not discredit the states' efforts to carry out its spirit.

It is arguable that this exercise of comity, however admirable, nevertheless violates the equal protection clause. Potential litigants could contrast Alabama's failure to impose liability in the above example with its treatment of defamation of residents by instate newspapers, defamation of nonresidents by instate newspapers, interstate broadcast of television signals defaming nonresidents, and so forth. ${ }^{238}$ By applying New York law in the case hypothesized, Alabama could be discriminating against instate defendants, against publications originating instate, or against publications received instate. Various choice of law theories reject the appropriateness of making each of these factors dispositive.

If subjected to strict scrutiny, could Alabama ever hope to demonstrate that such discriminations are necessary to achieve a compelling state interest? The state has only highly abstract interests in applying its law less broadly than the maximum that the full faith and credit clause tolerates: to extend a supererogatory comity to sister states, to encourage reciprocal courtesies, to diminish forum shopping, and, perhaps, to be a little fairer to parties who might not have expected that the state's law would govern their transactions. Even if these are compelling interests, unless Alabama adheres to a well defined choice of law methodology that the Supreme Court shares, it will not be able to demonstrate to that Court's satisfaction that its choice of law classifica-

Welch, Inc., 418 U.S. 323 (1974), it appeared that strict liability for media libel was never permissible. See Dun \& Bradstreet, Inc. v. Greenmoss Builders, 105 S. Ct. 2939, 2949 (1985) (White, J., concurring); L. TRIBE, supra note 46, at 640-41. But the limits of Gertz have been destabilized by the Court's recent holding in Dun $\mathbb{E}$ Bradstreet. See 105 S. Ct. at 2952 (White, J., concurring); id. at 2959 \& n.11 (Brennan, J., dissenting). Although the Court has never applied equal protection analysis to libel cases, the distinction between absolute immunity and strict liability for unintended defamation is so intrusive that heightened scrutiny seems appropriate. I will use this as a convenient hypothetical, while recognizing that its accuracy is debatable.

2s6 See Nevada v. Hall, 440 U.S. 410, 424-27 (1979).

237 See id. at $425-26$.

${ }^{238}$ The classifications resulting from choice of law decisions in these cases will frequently take the form of geographical discriminations, whether based purely on the location of conduct or on residence. 
tions are "precisely drawn" or "narrowly tailored" to achieve those interests. ${ }^{239}$ Thus, geographical classifications adopted to assign some multistate cases to another state's law will inevitably succumb to strict scrutiny, and possibly to less intrusive forms of "heightened" scrutiny as well.

A state's exercise of territorial restraint in these circumstances should not be condemned by equal protection merely because the state had the power to reach further. If moderation in exercising prescriptive jurisdiction provokes fatal equal protection challenges, then the only safe harbor is boundless self-assertion. States would be encouraged to respond in choice of law as many have in personal jurisdiction-to extend a long arm as far as the Constitution permits. ${ }^{240}$ In situations resembling the defamation pattern, the result would be very threatening to fundamental rights. An individual's rights would be restricted by the maximum number of conflicting state laws, invoked at the choice of a government $^{241}$ or private plaintiff, who would shop for the forum that would apply the law least favorable to the individual's rights under the particular circumstances of the case.

We may compare this hostile environment to the results produced by more restrictive choice of law rules. For example, consider a traditional choice of law rule: a defamation action is governed by the law of the state where the defamatory communication is received. ${ }^{242}$ Putting aside its merits as a choice of law rule, what danger does it pose to equality of rights? ${ }^{243}$ Under current law, the state of the injury can

299 Professor Simson agrees, and concludes that residence-based choice of law decisions relying on interest analysis always violate equal protection, whether fundamental rights are involved or not. See Simson, State Autonomy in Choice of Law: A Suggested Approach, 52 S. CAL. L. REv. 61, 86-87 (1978).

240 See, e.g., R.I. GEN. LAwS \$9-5-33 (1985); see also Kulko v. Superior Court, 436 U.S. 84 (1978) (finding that due process forbade particular exercise of personal jurisdiction under California long-arm statute that authorized jurisdiction as far as Constitution permits).

${ }^{241}$ Today, pure location discriminations typically control state assertions of criminal jurisdiction. State criminal laws are aimed at either conduct occurring within the state or conduct inflicting injury within the state. See Restatement (SECOND) of CONFLICT OF LAwS $\S 9$ (1971). Here the discrimination is especially blatant: because states do not enforce one another's criminal laws, the state will not apply foreign law but will leave the perpetrator of an out-of-state crime untouched or, on request, extradite her for trial and punishment by the other state. Yet there will be occasions where a state could, consistently with due process and full faith and credit, apply its criminal laws, including its criminal libel laws, to conduct occurring wholly within another state. See Garrison v. Louisiana, 379 U.S. 64 (1964) (stating modern constitutional standard for criminal libel law).

342 See Restatement of Confilct of Laws $\$ 377$ n.5 (1934).

${ }^{243}$ When the defamatory statement is received in many states, the resulting complexity of the case may impose serious burdens on the defendant, chilling the exercise of first amendment rights. See Pielemeier, Constitutional Limitations on Choice of Law: 
exercise both prescriptive and adjudicatory jurisdiction to subject the defamer to its law in its courts. Variations between the treatment the defendant would receive in those courts and the treatment she might receive in the courts of other states are no concern of the equal protection clause, because independent action of two states is involved. Similarly, when Alabama applies the law of New York, the state of the injury, rather than its own stricter law, it does not thereby express disrespect for the exercise of free speech within its own borders but rather recognizes the right of the people of New York independently to determine their own policy concerning the competing interests of speech and reputation in their own territory. Alabama acts neutrally by adhering to the law of the state of the injury, whatever it may be-more favorable, less favorable, or the same as Alabama law. It has not determined that one rule is right for Alabama and a different rule right for New York; rather, it has determined that the people of New York should make their own decisions about communications received within their borders, whether those decisions be right or wrong. And it is simply reaching the same result in its own court that would have been reached if the case had been brought in New York.

Special problems arise, however, when a forum state's decision to apply foreign law turns on the residence of the parties, and results in worse treatment for the nonresident. Discrimination against nonresidents evokes particular concern in our constitutional system, not only under the equal protection clause, but also under the privileges and immunities clause of article IV.

Because the privileges and immunities clause problem has attracted significant attention, ${ }^{244}$ it will be useful to examine that problem and then consider its implications for equal protection analysis, before finally deciding on the proper treatment of choice of law discriminations affecting fundamental rights. I will conclude that the privileges and immunities clause does require some judicial scrutiny of choice of law practices that discriminate against nonresidents, and that the same factors that feature in the privileges and immunities inquiry should inform the equal protection analysis.

\section{b. The Privileges and Immunities Perspective}

The privileges and immunities clause entitles "[t]he Citizens of

The Special Case of Multistate Defamation, 133 U. PA. L. REv. 381, 393-94 (1985). I will consider here only the locally circulated defamation. note 5.

244 See, e.g., Currie \& Schreter, supra note 224; Ely, supra note 5; Simson, supra 
each State . . to all Privileges and Immunities of Citizens in the several States." 245 Its language refers to citizens, but the Supreme Court has held that it condemns discriminations among citizens phrased in terms of residence as well as those explicitly turning on citizenship. ${ }^{248}$ The Court has also departed from the literal language of the clause by limiting its coverage "to those 'privileges' and 'immunities' bearing on the vitality of the nation as a single entity."247 Even such privileges and immunities can be withheld from nonresidents when the deprivation is justified by problems peculiar to their status. ${ }^{248}$ Thus privileges and immunities cases involve a two stage inquiry: a threshold examination of the kind of right at stake and a careful scrutiny of the reasons for the discrimination.

Some commentators argue that a state's discrimination against nonresidents should also trigger heightened scrutiny under the equal protection clause, principally because nonresidents, like aliens, are not represented in the state government and are therefore at the mercy of its self-interested decisions. ${ }^{248}$ The Supreme Court, however, has rejected this approach and analyzes these problems differently. First, it has repeatedly refused to articulate a higher level of scrutiny under the equal protection clause for discriminations against out-of-staters. ${ }^{250} \mathrm{It}$ has employed the privileges and immunities clause, where applicable, to police such discriminations. ${ }^{261}$ Second, the Court has interpreted the privileges and immunities clause as serving a broader purpose than merely compensating for lack of representation. "The primary purpose

245 U.S. ConsT. art. IV, §2.

${ }^{246}$ See, e.g., Hicklin v. Orbeck, 437 U.S. 518, 524 n.8 (1978).

247 Baldwin v. Fish \& Game Comm'n, 436 U.S. 371, 383 (1978); accord Supreme Court v. Piper, 105 S. Ct. 1272, 1276 (1985); United Bldg. \& Constr. Trades Council v. Mayor of Camden, 465 U.S. 208, 218 (1984). The precise meaning of the quoted phrase remains unclear. (1948).

${ }_{248}$ See Piper, 105 S. Ct. at 1278-79; Toomer v. Witsell, 334 U.S. 385, 396

${ }^{249}$ See J. ELY, supra note 46, at 86 ; Simson, supra note 239 , at 86 . Conceivably this argument would extend to heightened scrutiny of municipal ordinances discriminating against nonresidents of the municipality (including fellow citizens of the state). But see United Bldg. E Constr. Trades Council, 465 U.S. at 217-18; County Bd. v. Richards, 434 U.S. 5 (1977) (per curiam). Our present concern, however, is with state discrimination based on nonresidence in the state.

280 See Martinez v. Bynum, 461 U.S. 321, 328 n.7 (1983) (applying equal protection rational basis test; privileges and immunities clause inapposite because alien involved); G.D. Searle \& Co. v. Cohn, 455 U.S. 404, 408 \& n.6 (1982) (applying equal protection rational basis test; privileges and immunities clause inapposite because corporation involved); Baldwin, 436 U.S. at 388-89 (applying equal protection rational basis test; privileges and immunities clause inapposite because no "fundamental right" involved); McCarthy v. Philadelphia Givil Serv. Comm'n, 424 U.S. 645 (1976) (applying rational basis test; privileges and immunities clause inapposite).

${ }^{261}$ See, e.g., United Bldg. E Constr. Trades Council, 461 U.S. at 213-14. 
of this clause . . . was to help fuse into one Nation a collection of independent, sovereign States."262 It "remov[es] from the citizens of each State the disabilities of alienage in the other States."283 Third, the Court has also incorporated this fuller vision of national unity into its equal protection analysis, as illustrated by its decisions involving discrimination against newer residents of a state. An approach based solely on lack of representation would abandon the out-of-stater once she resettles and becomes eligible for the franchise in the new state. ${ }^{254}$

In fact, the Court has usually drawn exactly this line when interpreting the privileges and immunities clause. ${ }^{285}$ Although the Court has described the privileges and immunities clause as protecting a citizen "when he is within or when he removes to another State,"2s8 it has chosen to vindicate the continuing interest in national unity through the equal protection clause. The "right to travel" cases invalidated durational residence requirements for important rights and privileges that the state could have denied to nonresidents. These holdings were based on "the nature of our Federal Union and our constitutional concepts of personal liberty."257 More recently, the Court has labelled the state's desire to favor long-term residents over new arrivals as "constitutionally unacceptable," and has applied the rational basis test with more vigor than candor to permanent discriminations based on former residence elsewhere. ${ }^{288}$

252 Toomer, 334 U.S. at 395.

238 Paul v. Virginia, 75 U.S. (8 Wall.) 168, 180 (1868).

2st Thus, the political representation concern would take a new resident as far as Dunn v. Blumstein, 405 U.S. 330 (1972), which invalidated a durational residence requirement for voting, but not as far as Shapiro v. Thompson, 394 U.S. 618 (1969), which invalidated a durational residence requirement for welfare benefits, in the face of possible congressional authorization.

${ }^{28 s}$ See, e.g., United Bldg. \& Constr. Trades Council v. Mayor of Camden, 465 U.S. 208, 217 (1984); Zobel v. Williams, 457 U.S. 55, 59 n.5 (1982).

${ }_{2 s 8}$ Blake v. McClung, 172 U.S. 239, 256 (1898); see also Zobel, 457 U.S. at 7375 (O'Connor, J., concurring) (arguing that statute that denies non-Alaskans settling in the state the same opportunity to share in state rebate program as afforded longer term residents violated the privileges and immunities clause).

${ }^{237}$ Shapiro v. Thompson, 394 U.S. 618, 629 (1969); Memorial Hosp. v. Maricopa County, 415 U.S. 250, 254-55 (1974); accord Dunn, 405 U.S. at 343-44. But see Sosna v. Iowa, 419 U.S. 393 (1975); Chimento v. Stark, 414 U.S. 802 (1973), affg mem. 353 F. Supp. 1211 (D.N.H. 1973).

ass See, e.g., Zobel, 457 U.S. at 65; see also Hooper v. Bernalillo County Assessor, 105 S. Ct. 2862 (1985) (finding unconstitutional state statute that granted tax exemption only to Vietnam veterans who resided in the state before a specific date); Williams v. Vermont, 105 S. Ct. 2465 (1985) (finding unconstitutional Vermont statute that required car buyers who bought and registered cars outside of Vermont before becoming Vermont residents to pay full use tax, while car buyers who were residents at the time of purchase received a credit for taxes paid in a state that would reciprocate); $c f$. Attorney Gen. of N.Y. v. Soto-Lopez, 106 S. Ct. 2317 (1986) (four-Justice plurality relying on right to travel precedents; two concurring Justices relying on Zobel line of cases). 
Once choice of law methods changed from supposedly inevitable territorial principles to the exercise of free choice on policy grounds, the use of residence as a decisional factor began to look like a discrimination highly vulnerable to constitutional challenge. Professors Currie and Kay explored this darker side of their interest analysis approach to choice of law in the late 1950's. ${ }^{259}$ They tentatively concluded that the residence discriminations applied in choice of law might often be regarded as constitutionally inoffensive so long as nonresidents are subjected to the laws of their own domicile. ${ }^{200}$ Thus, even if New York had abolished the tort of defamation, it could entertain defamation suits against nonresidents under their own states' laws. Dean Ely has pursued this suggestion in his own direction. ${ }^{261}$ In accordance with his "representation-reinforcing" interpretation of the privileges and immunities clause, he argues that nonresidents do not need the protections of that clause when their legal obligations are defined by their own state government rather than by a state in which they lack political representation. ${ }^{262}$ Ely does not admire this "law of the domicile" conflicts methodology, but he offers, if only as a devil's advocate, a defense of its constitutionality. ${ }^{263}$

One difficulty with this representation-based defense is that it proceeds on too high a level of generality to redeem choice of law methodology as it might actually be practiced. If the forum state were to per-

The Court had long before characterized discrimination based on out-of-state residence as unconstitutional when indulged in for its own sake, see, e.g., WHYY, Inc. v. Borough of Glassboro, 393 U.S. 117, 120 (1968) but had not intrusively scrutinized proffered justifications when the discrimination was alleged to serve a purpose other than favoritism. See, e.g., Western \& S. Life Ins. Co. v. State Bd., 451 U.S. 648, 672 (1981). The Court's recent decision in Metropolitan Life Ins. Co. v. Ward, $105 \mathrm{~S}$. Ct. 1676 (1985), may suggest a more rigorous scrutiny even of discrimination against foreign corporations. It is possible, however, that the majority simply bungled the application of the conceivable rational basis test, viewing the issue too narrowly because of its procedural peculiarities. See id. at 1679-80. Then Justice Rehnquist's contemptuous dismissal of a similar challenge in Northeast Bancorp, Inc. v. Board of Governors, 105 S. Ct. 2545, 2555-56 (1985), may underline the aberrational character of the Metropolitan Life decision. Unfortunately, Justice Powell, the author of Metropolitan Life, did not participate in Northeast Bancorp and so had no opportunity to refute Justice O'Connor's claim that the two cases were irreconcilable. See id. at 2556 (O'Connor, J., concurring).

${ }^{280}$ See B. Currie, Selected Essays on the Conflict of Laws 445-583 (1963).

${ }^{260}$ See id. at $572 \& \mathrm{n} .183$.

201 See Ely, supra note 5, at 190-91.

262 See id. at 189-90; see also J. Ely, supra note 46, at 83-84.

${ }^{263}$ See Ely, supra note 5, at 211-17. Ely views Austin v. New Hampshire, 420 T.S. 656 (1975), as an obstacle to his analysis, but believes it was wrongly decided. See Ely, supra note 5, at 186-89. For a discussion of Austin, see infra text accompanying notes 282-91. 
mit all of a nonresident's rights and obligations to be governed by the laws of her domicile, the representation argument might have force. Indeed, a court might find that the nonresident had suffered no discrimination at all, because the body of law imposed on her was on the average no less favorable than the body of law imposed on local residents. ${ }^{264}$ But American states are unlikely to revert wholesale to acceptance of a personal law that a citizen carries with her. ${ }^{265}$ The modus operandi of modern choice of law is dépeçage: courts choose law issue by issue in the unique configuration of the litigation before them. ${ }^{268} \mathrm{In}$ a system of dépeçage, resort to domicile law on a single issue may be highly unfair to the nonresident. Defenses, for example, are tailored to rules of liability. Failure to discriminate on the basis of residence with regard to one issue can never violate the privileges and immunities clause, but it may fatally alter the effect of applying the law of the domicile with regard to another issue. A state that requires proof of malice by libel plaintiffs, for example, can reasonably provide fewer privilege defenses than a state imposing strict liability. If the forum gives every plaintiff the benefit of its own strict liability rule and relegates defendants to the privileges of their domicile, it cannot argue that nonresident defendants have only their legislatures to blame for their predicament. Rather, denying them the benefits of forum law puts them at an unfair disadvantage.

Reference to the law of a nonresident's domicile can also frustrate the broader purpose of the privileges and immunities clause: to fuse the states into a single nation by eliminating differential treatment of citizens of other states. Even if the clause was necessitated by the powerlessness of nonresidents, the solution the Framers chose was integration of visitors into the local system, not extraterritoriality. ${ }^{267}$ Both the wording of the clause ${ }^{288}$ and its interpretation ${ }^{268}$ suggest as a para-

sor The Supreme Court has employed such an average burden analysis in privileges and immunities clause cases involving differential taxation of residents and nonresidents. See, e.g., Austin, 420 U.S. at 665; Travis v. Yale \& Towne Mfg. Co., 252 U.S. 60, 80-81 (1920); Shaffer v. Carter, 252 U.S. 37, 55-57 (1920); Traveller's Ins. Co. v. Connecticut, 185 U.S. 364, 368 (1902); of. Kane v. New Jersey, 242 U.S. 160, 167 (1916) (holding that requirement that nonresident drivers appoint an agent within the state for receipt of process was not a discrimination against nonresidents because it merely "put[] nonresident owners upon an equality with resident owners").

205 See Ely, supra note 5, at 192.

208 See, e.g., Restatement (Second) of Conflict of Laws $\S \S 5,6, \& 9$ (1971). Currie and Kay, as well as Ely, pursue their analysis in this form. See, e.g., B. CURRIE, supra note 259, at 569; Ely, supra note 5, at 187 n.41.

287 See Paul v. Virginia, 75 U.S. (8 Wall.) 168, 180-81 (1868).

268 "The Citizens of each State shall be entitled to all Privileges and Immunities of Citizens in the Several States." U.S. ConST. art. IV, $\S 2$.

${ }^{269}$ See, e.g., Toomer v. Witsell, 334 U.S. 385, 396 (1948) (stating that the clause 
digm the right of a citizen of state $A$, while physically within the borders of state $B$, to interact with citizens of state $B$ on the same legal terms as those that govern their interaction among themselves. Although this seems to reflect an underlying assumption of territoriality too naive for modern conflicts thinkers, such attitudes were prevalent during the period when the clause was drafted and first expounded.

Nonresidents who are known to carry their domicile's law with them cannot participate as equals in the life of the state. (Imagine, for example, a lawsuit in which litigants from different states were subject to different rules regarding the privilege for defamatory statements made in the course of court proceedings.) Even where the nonresidents' own law is more favorable, its incompatibility with local practice may occasionally place them at a competitive disadvantage. Automatic approval of recourse to the law of the domicile maintains rather than reduces existing differentials in treatment between residents and nonresidents. Thus, this methodology does not foster "a national economic union."270

These considerations suggest that inhospitable choice of law decisions ought sometimes to be regarded as violations of the privileges and immunities clause. As a matter of precedent, however, the Supreme Court has never invalidated a choice of law decision under that clause. ${ }^{271}$ If the Court were eager to avoid all the difficulties application of the clause would entail, it could conceivably reject challenges to choice of law distinctions at the threshold. Under its current approach, the Court might claim that choice of law decisions, however idiosyncratic, "merely reflect the fact that this is a Nation composed of individual States, [rather than] bearing on the vitality of the Nation as a single entity,"272 and therefore escape the clause altogether. But if the Court is willing to grasp the nettle, it should recognize that unrestricted license to deny the benefits of forum law to nonresidents would impair the national unity goals of article IV, and it should move beyond the

\footnotetext{
"guarantees to citizens of State A [the privilege] of doing business in State B on terms of substantial equality with the citizens of that State"); Ward v. Maryland, 79 U.S. (12 Wall.) 418, 430 (1870) (stating that the clause "protects the right of a citizen of one State to pass into any other State of the Union for the purpose of engaging in lawful commerce").

${ }^{270}$ Supreme Court v. Piper, 105 S. Ct. 1272, 1276 (1985).

271 See J. MARTin, supra note 226 , at 332 . The age and the particular rationale of Conner v. Elliot, 59 U.S. (1 How.) 591 (1855), upholding a restriction of Louisiana's community property law to residents, make that decision an uninformative precedent. Austin v. New Hampshire, 420 U.S. 656 (1975), discussed infra at text accompanying notes 282-91, did not really involve choice of law because nothing in Maine law suggested that Austin should pay tax to New Hampshire.

${ }^{272}$ Baldwin v. Fish \& Game Comm'n, 436 U.S. 371, 383 (1978).
} 
threshold to require justification of the distinctions. ${ }^{273}$ Because my particular concern in this Article is discriminations affecting fundamental rights in the equal protection sense, which almost always are "fundamental" enough for article IV protection, ${ }^{274}$ and because many choice of law decisions affect the ability of nonresidents to compete as equals in a commercial setting, it is unnecessary for present purposes to decide whether choice of law decisions always involve privileges protected under the clause. ${ }^{275}$

Once the Court makes the threshold determination that a "privilege" or "immunity" is involved, the state can still defend its differential treatment of residents and nonresidents by showing that valid "reasons do exist and [that] the degree of discrimination bears a close relation to them."278 The standard of review is ill-articulated, but it appears to be neither as deferential as a rationality test nor as intrusive as strict scrutiny. Justice Brennan describes the relevant inquiry in the "substantial relationship" language associated with intermediate scrutiny under the equal protection clause. ${ }^{277}$ Not surprisingly, then Justice Rehnquist has written for the Court in less demanding terms. ${ }^{278}$ Most recently, Justice Powell employed the language of intermediate scrutiny with a soupçon of less restrictive alternative analysis, emphasizing the state's duty to seek methods of achieving its goals that do not rely on residence classifications. ${ }^{279}$ Thus, for a discrimination to be lawful under the clause, the state must show that it serves a purpose other

273 Conceivably, the Court could employ its vigilance at the threshold, distinguishing in some way between bona fide choice of law decisions and discriminatory denials of equality. Because the dividing line would probably remain like that proposed in the text, and because the "test" for justification under the privileges and immunities clause is ill defined, I doubt there is much practical difference between the two approaches. I regard the method I propose, messy as it is, as conceptually clearer.

${ }^{274}$ Cf. Doe v. Bolton, 410 U.S. 179, 200 (1973) (holding that privileges and immunities clause protects the rights of persons who enter a state seeking abortion services that are available there). But see Baldwin, 436 U.S. at 383 (right to vote not fundamental for purposes of the clause).

${ }^{275}$ For example, the privileges and immunities clause may be involved on the grounds that choice of law decisions inherently involve a nonresident's right to "[p]rotection by government" or the right "to institute and maintain actions in the courts of the State." See Corfield v. Coryell, 6 F. Cas. 546, 551-52 (G.C.E.D. Pa. 1823) (No. 3,230).

278 Toomer v. Witsell, 334 U.S. 385, 396 (1948).

${ }^{277}$ See Hicklin v. Orbeck, 437 U.S. 518, 527-28 (1978); Baldwin v. Fish \& Game Comm'n, 436 U.S. 371, 402 (1978) (Brennan, J., dissenting).

${ }^{278}$ See United Bldg. \& Constr. Trades Council v. Mayor of Camden, 465 U.S. 208, 222 (1984).

270 See Supreme Court v. Piper, 105 S. Ct. 1272, 1279 (1985). But it is well to heed the observation of Justice Blackmun that the "[c]lause is not one the contours of which have been precisely shaped by the process and wear of constant litigation and judicial interpretation." Baldwin, 436 U.S. at 379. 
than disfavoring nonresidents, and that the means are substantially adapted to the ends.

Applying this standard to unfavorable choice of law decisions based on residence, the state should be permitted to show that the presence of a nonresident creates a substantial problem justifying displacement of forum law. Normally the problem will arise out of fairness or comity concerns because the forum has reason to believe that another state has a greater interest than the forum in providing the governing law. ${ }^{280}$ The forum state should point to circumstances making these concerns realistic: the mere fact that a nonresident is a party, or that the other state would cheerfully apply its own law if it were the forum, should not be enough. Otherwise, the interest in national unification and equal participation in the economic and social life of the states by nonresidents would be sacrificed to adherence by some states to jingoistic choice of law methodologies. For example, New York should not be permitted to apply a stricter New Jersey libel rule to a case where a New Jersey resident employed as a reporter in New York by a newspaper circulated only in New York defames a New York resident. This requirement necessarily implies that the federal courts will weigh state interests more freely in privileges and immunities cases than they do in full faith and credit cases. But they still would not need to select a single conflicts approach as correct.

Even if the state asserts a legitimate purpose, it must show that application of law of the domicile is substantially related to achieving that purpose. The substantial relationship test requires that the state be acting with a modicum of consistency, rather than oppressing nonresidents by singling out particular issues within a case in a manner that subjects them to a less favorable law. If the state is pursuing a coherent choice of law strategy sincerely designed to protect expectations and to defer to greater interests, then it should have no trouble passing this test. The Supreme Court itself regards states as having a greater inter-

${ }^{280}$ I have not mentioned a further purpose that the discrimination might serve: prevention of forum shopping. I must confess to some skepticism about this motive for discrimination against nonresidents. For application of the law of the domicile to be effective in preventing forum shopping, it would have to be true that every other state (at least every other state where the suit could be brought) would have applied the law of the same party's domicile. Generally, this means that there is reason to believe that this domicile state has a greater interest. If the state's interest is only in diminution, not eradication, of forum shopping, a parallel argument can be made with somewhat less force. Nor have I included as a separate factor the subjective expectations of the parties: (1) the notion is inevitably circular; (2) legitimate expectations must be unusually weak today given the chaos in conflicts law; and (3) most importantly, legitimate expectations could arise only if the parties had reason to believe that the domicile's interest was greater than that of the forum. 
est in the conduct and welfare of their own residents than in that of nonresidents. ${ }^{\mathbf{2 8 1}}$ Thus, it should recognize that a state exercising comity has no alternative to including residence as a factor in choice of law decisions.

I do not contend that the standard just described provides a bright line rule under which privileges and immunities issues in choice of law will be child's play to resolve. Since we left Beale's false Eden, nothing in this field is child's play. I do suggest, however, that this standard represents the appropriate accommodation of protection for nonresidents and ecumenism in choice of law methodology.

The standard above might still be regarded as too permissive, in light of the interpretation some commentators have given the Supreme Court's opinion in Austin v. New Hampshire. ${ }^{282}$ Austin, a Maine resident, challenged a New Hampshire income tax that was imposed only on New Hampshire income of nonresidents. The Court invalidated the scheme, even though the tax would have been reduced to zero if the Maine legislature had refused to credit its payment toward satisfaction of Maine's own income tax. ${ }^{283}$ Justice Blackmun dissented, arguing that Maine, not New Hampshire, was the source of the problem. ${ }^{284}$ The Court rejected this defense, however, holding that the privileges and immunities clause required more than state conduct inviting retaliatory action to restore equality. ${ }^{285}$ "Nor, we may add, can the constitutionality of one State's statutes affecting nonresidents depend upon the present configuration of the statutes of another State."286

Austin does not necessarily invalidate the law-of-the-domicile approach. First, Austin was not really a choice of law case: nothing in Maine law required payment of taxes by Maine residents to New Hampshire. ${ }^{287}$ Second, the Court's ire in Austin was provoked by a state scheme that imposed a financial burden on nonresidents only, and then allowed their home legislatures to eliminate that burden, but only to the extent of restoring equality between nonresidents and residents.

281 See, e.g., Phillips Petroleum Co. v. Shutts, 105 S. Ct. 2965, 2979 (1985); Allstate Ins. Co. v. Hague, 449 U.S. 302, 314-17 \& nn. 19-20 (1981); Sosna v. Iowa, 419 U.S. 393 , 406-07 (1975).

282420 U.S. 656 (1975). See, e.g., J. MARTIN, supra note 226, at 377-78, 633; Ely, supra note 5, at 186-87 ("If Austin is right as written, the dominant contemporary choice-of-law theory is unconstitutional.").

283 Austin, 420 U.S. at 666-67.

284 See id. at 668-69 (Blackmun, J., dissenting).

285 See id. at 666-67.

288 Id. at 668.

287 See Ely, supra note 5, at 186. Ely describes New Hampshire's action as "tax[ing] an out-of-stater at the rate his home legislature had selected." Id. It is thus precisely the kind of lifting of a legal rule out of its context that I have criticized above. See J. MaRTin, supra note 226, at 377-78. 
The New Hampshire scheme did not achieve the average reciprocity of advantage between citizens and noncitizens in New Hampshire afforded by a true law-of-the-domicile approach. ${ }^{288}$ The calculated onesidedness of New Hampshire's scheme should be regarded as essential to the Court's holding. ${ }^{289}$ Even this narrower reasoning, however, would appear to invalidate one version of Currie's suggested solution: allowing the nonresident the lesser of the protections of forum law and her domicile's law. ${ }^{290}$

My conclusion from this lengthy digression is that, contrary to Dean Ely's preferred approach, ${ }^{201}$ the privileges and immunities clause should be restrictive enough to protect nonresidents from hostile discriminations in choice of law, even when the discriminations take the form of incorporating the law of their domicile. Armed with this conclusion, what can we say about the relation between fundamental rights equal protection and residence-based choice of law rules?

\section{c. Fundamental Rights Equal Protection and Choice of Law}

I argued earlier that some apparent discriminations in the choice of law ought not to trigger heightened scrutiny for two reasons: first, because they can reflect a praiseworthy form of deference to the sovereign lawmaking power of the people of a sister state; and second, because they respond to inevitable variations in the scope afforded to fundamental rights by different states, rather than creating inequalities themselves. The Constitution itself makes residence or presence in a state a basis for subjection to laws adopted by that state as a political community, and recognition of this fact is not in itself offensive to principles of equal protection. To the extent that this argument applies to particular discriminations, they should escape heightened scrutiny.

Residence discriminations capable of disfavoring out-of-staters may not serve these purposes-states have an obvious incentive to employ residence discriminations in order to bias the outcome of litigation between residents and nonresidents, or otherwise to reserve the benefits of local law for their constituents. Those residence discriminations that

${ }^{288}$ This latter approach, of course, would give out-of-staters the benefit of more favorable domicile law as well as the burden of less favorable domicile law.

${ }^{289}$ The Court's opinion in Austin drew on a significant body of prior law on taxing discrimination under the privileges and immunities clause. In those earlier cases, the Court required only substantial equality between residents and nonresidents: an approximate parity in the tax burden on the nonresident and on the average resident of the state. See Austin, 420 U.S. at 665 n. 10; Traveller's Ins. Co. v. Connecticut, 185 U.S. $364,368-69$ (1902).

290 See B. Currie, supra note 259 , at 569-72.

291 See Ely, supra note 5, at 189-91. 
survive the proposed scrutiny under the privileges and immunities clause, however, have already been validated as reasonably serving the goal of deference to a more interested sister state. Accordingly, they should not trigger heightened scrutiny when the subject matter of the choice of law involves a fundamental right.

Thus the privileges and immunities clause effectively supersedes fundamental rights equal protection in the analysis of residence classifications in choice of law, so far as claims of discrimination against citizens of sister states are concerned. The equal protection clause still has an independent role to play, however, when state residents or corporations or resident aliens are disfavored by residence classifications, because they are not protected by the privileges and immunities clause. ${ }^{202}$ Similarly, pure location discriminations require independent equal protection analysis.

Though out-of-state resident aliens and corporations do not vote in any state, still they are members of a self-governing community that may have a greater interest in determining their rights and duties than the forum state has. Family law for aliens and libel and shield laws for media corporations might be cited as possible examples. ${ }^{293}$ Once more, deference to the sovereignty of a sister state over its noncitizen residents ought to be encouraged and ought not to trigger heightened scrutiny. Because the state will still have an incentive to disfavor nonresident aliens and corporations, residence discriminations cannot simply be assumed to reflect such deference. ${ }^{284}$ On the other hand, the demands of national unity are not as great with regard to aliens and corporations as with regard to citizens. Thus a somewhat more deferential version of the inquiry pursued under the privileges and immunities clause should be employed: only if the forum state purports to be deferring to a state with greater interest, only if that characterization is rational, and only if the choice of law decision adopts enough of the domicile's law that it may reasonably be said to further that goal, should the forum's adoption of domicile law be excused from heightened scrutiny.

Discriminations against the state's own residents also require separate treatment, because they raise no questions under the privileges

292 See supra notes 35 and 250.

293 See, e.g., Hanley v. Tribune Publishing Co., 527 F.2d 68 (9th Cir. 1975) (dispute over application of California or Nevada retraction law in a libel suit by $\mathrm{Ne}$ vada plaintiff against California publisher); Mazzella v. Philadelphia Newspapers, Inc., 479 F. Supp. 523 (E.D.N.Y. 1979) (applying Pennsylvania shield law).

284 See, e.g., Metropolitan Life Ins. Co. v. Ward, 105 S. Ct. 1676, 1683 (1985) ("A State's natural inclination frequently would be to prefer domestic business over foreign."). 
and immunities clause. ${ }^{295} \mathrm{~A}$ state has little incentive to disfavor its own electorate, and hostility to a fundamental right is more likely to be reflected in a restrictive substantive rule applicable to residents and nonresidents alike than in a discrimination against local residents. In the rare instances where a discrimination favoring nonresidents on its surface impairs their position of equality in the state, nonresidents can vindicate the interest in national unity by challenging the scheme. Accordingly, the same slightly more deferential test articulated for aliens and corporations should be applied to determine when a residence discrimination favoring out-of-staters escapes heightened equal protection scrutiny.

Similarly, even pure location discriminations, which never raise privileges and immunities issues, should be judged by the same standard. Ghoice of law decisions in which the location of a particular act becomes a decisive factor are likely to reflect a defensible choice of law methodology, though there may be instances where the chosen act is so marginal that it cannot justify the discrimination. ${ }^{286}$ The greater danger is that the state will abuse the method of dépeçage, for example, by denying a local defense for defamatory statements originating out of state while applying the local standard of care. As I have argued earlier, a location discrimination can have a differential impact almost as onerous on residents of the disfavored locality as an explicit residence discrimination would have. Pure location discriminations should not be excused from heightened scrutiny until the court has determined, by the inquiry outlined above, that they represent genuine deference to the interests of another state, and not a trap for an out-of-state actor.

As an illustration, consider the traditional defamation privilege for statements made in the course of judicial proceedings. ${ }^{207}$ Suppose that Alabama not only imposes liability for negligent defamation, but also abolishes the judicial proceedings privilege altogether. Suppose further that New York provides an absolute privilege for all statements made in judicial proceedings. Finally, suppose an Alabama resident alien sues some New York resident aliens in Alabama, alleging that they defamed her in the course of an earlier lawsuit in New York. If Alabama concludes that the rules for both liability and privilege in such cases should

205 See, e.g., United Bldg. \& Constr. Trades Council v. Mayor of Camden, 465 U.S. 208, 217 (1984).

290 For example, the traditional rule that the place of contracting has an overriding interest in determining the effect of the contract has been derided by modern commentators, who question whether it has any interest at all. See B. CurRIE, supra note 259, at 582-83; Simson, supra note 239, at 83.

297 See, e.g., Restatement (SECOND) OF ToRTs $\$ 586$ (1977) (attorneys' privilege); id. $\S 587$ (parties' privilege). 
be dictated by the state in whose courts the prior litigation occurred, then the pure location discrimination is rational and should be upheld. First, Alabama could rationally conclude that the prior forum has a greater interest in striking an appropriate balance between zealous advocacy in pursuit of justice and protecting itself from being used as a vehicle for malicious defamation, even of Alabama residents; second, the adoption of the prior forum's law as to both the claim and the defense reasonably furthers the goal of deference to forum policy. Accordingly, heightened scrutiny should not be applied, and the discrimination should be upheld as rational. In contrast, if Alabama concludes that the domicile of the plaintiff dictates rules for both liability and privilege, then heightened scrutiny is required. The result of Alabama's choice of law rule is to treat all litigation between its residents and those of New York-and especially such litigation in Alabama's own courts-as an unequal contest. Alabama residents are free to defame, and New York residents are disabled from replying in kind. It is not rational to conclude that New York has an overriding interest in subjecting its residents to such an ordeal. ${ }^{298}$ Thus, whatever other purposes Alabama's choice of law rule might serve in this context, it does not rationally serve the purpose of deferring to the policy choices of a state with greater interest. Accordingly, it will not be excused from heightened scrutiny of its impact on first amendment rights.

\section{d. Interstate Variations Not Resulting from Choice of Law}

Thus far I have been discussing geographical discriminations along state boundary lines by which a state exercises its prescriptive jurisdiction only with respect to transactions involving its own residents or occurring within its borders. The state may dispose of other cases by applying the law of another state, or by renouncing jurisdiction. Renunciation of jurisdiction is the usual rule in criminal cases. ${ }^{290}$ It may also appear in civil cases under the doctrine of forum non conveniens ${ }^{\mathbf{3 0 0}}$ or through unwillingness to enforce the "penal" statutes of another sovereign.

When the state does choose to exercise prescriptive jurisdiction over out-of-state transactions, and does so by adopting a special rule

208 A plaintiff-centered choice of law methodology cannot be accepted as rational merely on a general theory that a plaintiff's state always has the greatest interest in providing the rule of decision even if there exist other, more favorable rules. Such a theory would automatically validate all discrimination against nonresident plaintiffs.

${ }^{209}$ See W. LaFave \& I. IsRael, Criminal Procedure § 16.2(c) (1984).

300 See Stein, Forum Non Conveniens and the Redundancy of Court Access Doctrine, 133 U. PA. L. REV. 781, 785 (1985). 
differing from its local law, normal equal protection principles should apply. The state cannot defend its actions as deference to the self-governing authority of sister states, because the state has presumed to make their choices for them. When the resulting discrimination affects fundamental rights, whether it favors in-staters or out-of-staters, heightened scrutiny is appropriate. For example, if Alabama imposed a malice standard for libel by in-state newspapers, and a strict liability standard for out-of-state newspapers regardless of the law of their domiciles, the favoritism toward local publishers would cry out for intensive equal protection review.

\section{Third Special Position-Special Laws and Local Option Laws, with a Digression on Circuit Conflicts}

When the state as a whole takes actions that create disparities in the scope of fundamental rights between geographical regions within the state whose boundaries coincide with those of political subdivisions of the state, these actions may also raise equal protection problems. I have argued earlier that "random" geographical discriminations, whose contours are not defined by political boundaries, deserve scrutiny as close as that afforded to other nonsuspect classifications. On the other hand, I have argued that discriminations attributable to the state within the federal constitutional framework but resulting from independent action of self-governing political subdivisions should escape heightened scrutiny. These examples are polar extremes on a spectrum that must now be confronted.

Two traditional methods for tailoring state policies to local conditions are "special" legislation and "local option" laws. ${ }^{301}$ In the local government context, the term "special" legislation refers to statutes passed by the state legislature, but operative only within certain named municipalities, ${ }^{302}$ or only within a "class" of municipalities, frequently a class defined by population. ${ }^{303} \mathrm{I}$ will use this term to describe any

301 See, e.g., 2 E. MCQuillen, The Law of Municipal CoRporations $\$ 4.48$ (3d ed. 1979). Special legislation can also refer to other forms of discriminatory classification not involving geography. See 1 C. Antieau, Municipal Corporation Law $\$ 2.14$, at $2.37-.38$ (1982). Geographically defined special legislation is sometimes known as "local" legislation, but I will not use this term here to avoid confusion with "local option" legislation.

${ }^{302}$ See, e.g., McGowan v. Maryland, 366 U.S. 420 (1961) (upholding state Sunday closing law with variant provisions for one county); 2 E. MCQuILLEN, supra note 301 , at $\$ 4.56$ and cases cited therein.

sos See, e.g., North v. Russell, 427 U.S. 328 (1976) (upholding system of first tier trial before lay judges in cities of lesser population); 2 E. MCQuilleN, supra note 301, at $\$ 4.57-.72$ and cases cited therein. 
state statute limited in its applicability to one or more political subdivisions, but less than the whole state. ${ }^{304}$ "Local option" laws, which I will discuss later, provide that their dictates will apply only in those communities that accept the option or, conversely, that fail to refuse it. $^{305}$

Both of these techniques can serve a valuable function in accommodating expressed local preferences concerning matters that the state is reluctant to commit wholly into the hands of local government. Distrust of investing too much power in local governing bodies has long been a countertheme of American politics. ${ }^{308}$ In many states, the structure of municipal home rule has limited local government authority to matters of "local concern" and has included among the matters of "general" or "statewide" concern reserved to the state as a whole the definition of basic rules of civil obligation that had been governed by the common law in England. ${ }^{307}$ To return to Justice Bradley's example in Missouri $v$. Lewis, ${ }^{308}$ if the people of New York really wanted to adopt the civil law for New York City and the common law for the rest of the state, they would normally have to act through the state legislature; the usual state law home rule doctrines, which New York shares, deny a city the power to make so sweeping a change in the civil obligations of its residents. ${ }^{309}$ To vary another prior example, if the state wished to adopt a lower age for valid marriage in small towns than in big cities, action at the state legislative level would also be required.

Absent state consitutional restrictions, ${ }^{\mathbf{3 1 0}}$ special legislation may be

so4 Thus, the use of the term here will be narrower than in some states, where special legislation includes laws having no geographical limitation or where local option laws potentially effective statewide are still regarded as special, and broader than in some states, where the term special legislation refers to the conclusion that the geographical restriction lacks a justification that would take it outside the scope of a relevant state consitutional prohibition.

${ }^{305}$ See, e.g., Rippey v. Texas, 193 U.S. 504 (1904) (local option to impose prohibition on sale of liquor); City of Canton v. Whitman, 44 Ohio St. 2d 62, 337 N.E.2d 766 (1975) (local option to avoid state fluoridation statute), app. dismissed, 425 U.S. 956 (1976).

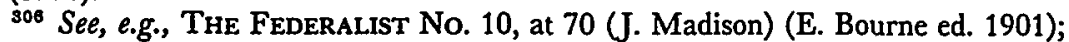
see also Frug, supra note 194, at 1106 (arguing that liberal theory limited city power in order to vindicate primacy of individual over group rights).

so7 See, e.g., 1 C. ANTIEAU, supra note 301, at §3.08; O. REYNolds, Local GOVERNMENT LAW 122-23 (1982); Sandalow, supra note 214, at 674-79.

${ }^{308} 101$ U.S. 22, 31 (1880).

soo See N.Y. STat. Local Gov'Ts Law § 11(4) (McKinney 1969). Of course, this limitation on the powers of home rule cities is wholly one of the state's own making, and federal equal protection doctrine need not necessarily be shaped to accommodate it.

s10 Many state constitutions contain restrictions on the power of the state to enact special legislation. See, e.g., AlA. ConST. art. II, § 19; CAL. ConST. art. IV, § 16; VA. ConsT. art IV, $\S 14$. Some of these derive from nineteenth century struggles against 
enacted in a variety of ways: at the request of the affected municipality speaking through its mayor or council, ${ }^{311}$ in response to the desires of the delegation in the state legislature representing the voters of the municipality, or imposed by the state despite the indifference or objection of the municipality. ${ }^{\mathbf{3 1 2}}$ The Supreme Court has on numerous occasions upheld special legislation against equal protection challenges, though in cases not involving fundamental rights claims. ${ }^{313}$ Ought special legislation be treated as a vehicle for self-determination and appropriately be excused from heightened equal protection scrutiny?

If the passage and repeal of special legislation were automatically assured whenever requested by the local government to be affected, and if such legislation could never be passed without that government's consent, then the technique of special legislation would be tantamount to home rule and could justifiably be afforded the same treatment. But this is neither the theory nor the reality of special legislation. In most states, unfavorable special legislation can be imposed on municipalities over their opposition. ${ }^{314}$ Even in those states where special legislation cannot be passed without some manifestation of municipal consent, special legislation may be blocked by legislative inertia, parochial jealousy, or the desire of other representatives to extract political bargains from the affected community or its delegation. If one community obtains a

legislative depredations on municipalities, see, e.g., O. REYNOLDS, supra note 307 , at 85-86; Sandalow, supra note 214, at 674-79, while others reflect general concerns about legislative powers of classification and discrimination. See, e.g., H. McBain, The Law and Practice of Municipal Home Rule 91-92 (1916). State courts construing these provisions have generated thoroughly murky doctrines for distinguishing the forbidden special legislation from that which is limited to certain municipalities but nonetheless not "special" in the relevant constitutional sense. See, e.g., 2 E. MCQuilleN, supra note 301, at $\$ \S 4.30-.76$; F. Michelman \& T. Sandalow, Materials on Government IN URBan AREAS 336-47 (1970). Fortunately, we can wholly ignore these distinctions for present purposes, because all forms of special legislation share the same material characteristics from the equal protection point of view, except that some cases have regarded statewide local option laws as "special." See infra notes 315-18 and accompanying text. I argue below that local option laws should be treated differently.

s11 See, e.g., Mass. Const. art. II, §8; N.Y. Const. art. IX, § 2.

312 See H. McBAIN, supra note 310, at 6-12, 45-46, 59-62, 103-105. For a modern example, see Paddock v. Town of Brookline, 347 Mass. 230, 197 N.E.2d 321 (1964) (striking down special legislation waiving notice requirement for an individual in suit against named town).

313 See, e.g., North v. Russell, 427 U.S. 328 (1976); McGowan v. Maryland, 366 U.S. 420 (1961); Salsburg v. Maryland, 346 U.S. 545 (1954); Packard v. Banton, 264 U.S. 140 (1924); Stewart v. City of Kansas City, 239 U.S. 14 (1915); Gardner v. Michigan, 199 U.S. 325 (1905); Hayes v. Missouri, 120 U.S. 68 (1887). But see Mason v. Missouri, 179 U.S. 328 (1900) (upholding special legislation regarding voter registration).

s14 See 2 E. McQuillen, supra note 301, at $\S 4.31$. But see MinN. Const. art. XII, § 2; N.Y. CoNST. IX, § 2 (both requiring local consent to special laws). 
special law expanding the scope for exercise of a fundamental right within its borders beyond that available in the state as a whole, there can be no guarantee that other communities that seek equal status will succeed. Even when a community has achieved its desire to obtain special legislation, if a future electorate concludes that it wishes to restore equality with its neighbors by having the legislation repealed, it cannot be certain of success. In short, special legislation in its geographical form is no less a type of classification imposed and maintained by the state as a whole than special legislation respecting commercial, ideological, or ethnic groups. Such legislation does not constitute an ongoing process of self-determination by the affected population, and the approach advocated in this Article would not entail excusing it from heightened equal protection scrutiny.

Local option laws, like special legislation, involve express geographical discriminations on the face of the statute. They differ from special legislation, however, in that they permit the state to compromise between local autonomy and protection of local minorities in a manner less threatening to equality of rights. State courts have disagreed as to whether local option laws are merely another form of special legislation subject to state constitutional prohibitions. Some older cases held that any geographical variation resulting from exercise of local options represented the kind of disuniformity that the state constitution disables the state legislature from creating. ${ }^{318}$ These cases reflect a broad distrust of disuniformity, whatever its cause, but a narrower charge could have been levelled against local option laws: that the agenda control involved in most local option legislation nudges communities into contrasting positions, creating a state-induced disparity that the ban on special legislation was intended to prevent. ${ }^{\text {ii }}$ Other courts held that so long as a local option law was potentially effective in every part of the state, the state had not imposed a lack of uniformity, and the legislation should not be regarded as "special"; this position is dominant today. ${ }^{317}$

s1s See, e.g., Appeal of Scranton School Dist., 113 Pa. 176, 6 A. 158 (1886).

s16 Compare, for example, the degrees of local choice available in the liquor option statutes in Rippey v. Texas, 193 U.S. 504 (1904) (dry or wet); Harrison v. State, 687 P.2d 332 (Ala. App. 1984) (wet or licensed or prohibition of sale only or prohibition of both sale and importation); and Brunswick Corp. v. Liquor Control Comm'n, 184 Conn. 75, 440 A.2d 792 (1981) (town permitted to impose any system more restrictive than enumerated state options, but bowling alley liquor licenses not to be issued in town opting to limit sale of alcohol to beer only). But see Arlan's Dep't Stores v. Kelley, 374 Mich. 70, 130 N.W.2d 892 (1964) (condemning local option Sabbath closing law for opposite fault: providing full spectrum of choices violates nondelegation doctrine).

s17 See, e.g., Gity of Canton v. Whitman, 44 Ohio St. 2d 62, 337 N.E.2d 766 (1975), app. dismissed, 425 U.S. 956 (1976); 2 E. MCQuillen, supra note 301, at $\S 4.49$. If the option is not available uniformly throughout the state, however, the stat- 
Finally, some cases have taken an intermediate position, holding that time limits on the exercise of the option foster disuniformity in a manner that renders the legislation special. ${ }^{318}$

From the equal protection point of view, the constitutionality of local option laws has long been regarded as settled. Early in this century, the Supreme Court rejected equal protection challenges to local options for the prohibition of liquor. ${ }^{318}$ The Court dismissed the claims of discrimination on the typically Holmesian grounds that the state could have accomplished the same result by passing special legislation affecting only the accepting communities, and that the constitutionality of the greater discrimination entailed the constitutionality of the lesser. ${ }^{320}$

At the risk of standing this historical justification on its head, I would contend that local option laws are more consistent with equal protection principles than special laws are. If a local option law is framed so that a community can, by popular vote or by vote of its elected representatives, pass in and out of its scope over time, ${ }^{\mathbf{2 2 1}}$ then the local option is equivalent to a very limited grant of home rule authority over a particular subject. No community is disadvantaged vis-avis any other except insofar as a current majority of the electorate wishes to be disadvantaged. ${ }^{322}$ Local self-determination may be limited to a choice among a discrete set of options specified by the state legislature, rather than an unconstrained choice among the full range of policy approaches to the given subject matter, but within those limits the state has afforded self-determination nonetheless. It is not necessary to excuse the resulting geographical discrimination from heightened scrutiny to achieve self-determination; the state could always resign its

ute may be regarded as special. See, e.g., Nomey v. State, 315 So. $2 d 709$ (La. 1975); Ex parte Smith, 231 Mo. 111, 132 S.W. 607 (1910).

${ }_{318}$ See, e.g., De Hart v. Atlantic City, 63 N.J.L. 223, 43 A. 742 (1899).

319 See Ohio ex rel. Lloyd v. Dollison, 194 U.S. 445 (1904); Rippey v. Texas, 193 U.S. 504 (1904).

${ }^{320}$ See Rippey, 193 U.S. at 509-10 (Holmes, J.); Lloyd, 194 U.S. at 448-49 (citing Rippey); cf. Fort Smith Light \& Traction Co. v. Board of Improvement, 274 U.S. 387,391 (1927) (holding that if state can delegate to municipality authority to enact local law, then state can enact local law itself).

s21 See, e.g., Rippey, 193 U.S. at 504 (local option liquor law reexaminable from time to time, except that lesser included subdivisions may not go wet while a prohibition election at a higher level remains in force). But see Town of Seabrook v. Perkins, 112 N.H. 37, 288 A.2d 688 (1972) (local option to permit licensing of a dog track cannot be rescinded); Whitman, 44 Ohio St. $2 \mathrm{~d}$ at 62,337 N.E.2d at 766 (only one opportunity to avoid fluoridation).

322 Local option laws may be framed to require a supermajority for certain actions. $C f$. Gordon v. Lance, 403 U.S. 1 (1971) (finding that a requirement of $60 \%$ vote of community for incurring bonded indebtedness or increasing ceiling on tax rate did not violate equal protection). 
agenda control and grant full home rule power over the subject matter, rather than imposing the particular compromise between autonomy and centralization that it has selected. But the degree of independence resulting from home rule should not be exaggerated. The limits imposed by the state constitutional or statutory provisions defining the basic grant of home rule also involve agenda control. ${ }^{323}$ The requirement that local ordinances be consistent with state legislation on matters of general concern also involves agenda control. ${ }^{324}$ The tradition of municipal self-government in this country since independence has not been one of plenary local power unencumbered by state direction. ${ }^{325}$ Thus, the difference between local option and home rule is one of degree: the same local institutions make the choices, but the range from which they can select is more or less restricted by the state. ${ }^{326}$ Therefore, the contribution of the option process to local self-determination can justify treating the resulting departures from equality as generously as independent local choices made outside a local option framework are treated.

This argument for equal protection toleration of local option legislation depends on the legislature providing its municipalities basically equivalent opportunities to choose, both now and in the future. That is, every part of the state must be included within a unit that is authorized to accept or reject the option, and units that repent their earlier choices must have the power to revise them subject to appropriate waiting periods or prospectivity conditions. ${ }^{327}$ If the choice between options, once

s23 See 2 E. MCQuilLEN, supra note 301, at §§ 10.13-.16; Frug, supra note 194, at $1116-17$.

s24 See 2 E. MCQUILLEN, supra note 301 , at $\S 9.08$ b.

325 See A. DE TocQueville, supra note 193, at 67; H. MCBAIN, supra note 310 , at $14-16$.

s26 Indeed, from a federal constitutional point of view, a grant of local decisionmaking authority in a state constitution has no more exalted status than an identical grant contained in a statute. Special legislation, in contrast, differs from both state constitutional and statutory grants by more than a matter of degree: a community must always seek consent from a statewide institution for every enactment or repeal of special legislation.

${ }^{327}$ Waiting periods may be justified to prevent the chaos resulting from continual referenda. See Nomey v. State, 315 So. 2d 709, 724 (La. 1975) (liquor prohibition referendum may be repeated every second year). A variety of such techniques have been approved in other electoral contexts. Compare Storer v. Brown, 415 U.S. 724, 728 (1974) (independent candidate required to wait one year after association with political party before being placed on ballot) and Rosario v. Rockefeller, 410 U.S. 752, 762 (1973) (voter must enroll in political party 30 days before general election to be eligible to vote in the party's primary election the following year) with Anderson v. Gelebrezze, 460 U.S. 780, 805-06 (1983) (requirement that independent candidate for President of the United States file nominating petition in March for November election held unconstitutional) and Kusper v. Pontikes, 414 U.S. 51, 60 (1973) (requirement that voter wait 23 months before voting in different party primary held unconstitutional). Prospectivity requirements may be appropriate to avoid injustice to those who have justifia- 
made, is binding on the community until such time as the state legislature can be persuaded to release it, then many of the inequities inherent in special legislation will infect the local option process. A one-time local option is not comparable to the self-imposed fetters of a constitution, because even the unanimous assent of the community is ineffective to repeal the option without the concurrence of outsiders. Thus, to deserve the special equal protection treatment accorded to ongoing processes of local self-determination, a local option must be susceptible to reevaluation..$^{328}$

Moreover, the availability of the local option to each community must be more than an empty form. The state's control of the agenda may be so extreme that some communities have no realistic opportunity to avail themselves of the same options as other communities. Suppose, for example, that a local option law addressing the scope of fundamental rights requires that the options be accepted by a vote taken at a town meeting attended by more than seventy-five percent of the municipal electorate. Only rather small towns would be physically capable of accepting such an option. Suppose instead that the state law sets twenty-one as the minimum age for marriage, but permits municipalities to lower the age to sixteen so long as they provide every minor couple with a ten-acre farm within the town limits. Sparsely settled farming communities could accept this option, but cities probably could not. In either case, the purported local option is so limited in its availability that any resulting disuniformities in the distribution of fundamental rights must be regarded as state-fostered discrimination, not local self-determination. As I will discuss later in the Article, this conclusion has serious consequences for the situation in which a town's options are restricted by its ability to pay.

If the foregoing argument is accepted, then, contrary to Justice Holmes' contention, there will be situations in which the state and its municipalities combined can create geographical disparities through the local option procedure that the state itself could not impose directly. ${ }^{329}$

bly relied on the community's prior choice. Cf. Town of Seabrook v. Perkins, 112 N.H. $37,40,288$ A.2d 688, 690 (1972) (local option to permit licensing of a dog track cannot be rescinded).

${ }^{328}$ Furthermore, the geographical units voting on a local option affecting fundamental rights should be existing political subdivisions of the state, rather than ad hoc units chosen by the legislature for a particular option law. If the state were free to gerrymander the voting units with an eye to the content of the option, then the system would lack the relative impartiality that lulls our concerns about conferring continuing powers of self-determination on municipalities.

s29 There may be certain situations, however, in which the Constitution itself demands statewide uniformity and does not permit local option. The example that clearly comes to mind is equal participation in elections for statewide offices. The reapportion- 
Like special laws, executive or judicial lawmaking that imposes different rules in different political subdivisions within the state can raise similar equal protection problems. If a statewide administrative agency adopts a regulation discriminating among different regions, one should treat this regulation exactly as one would treat special legislation with the same content. If distinct offices of a state agency, each with its own geographical jurisdiction, adopt different regulations for their territories, then the resulting discrimination must be attributed to the state as a whole for equal protection purposes. ${ }^{330}$

Similarly, discriminations within the judicial branch can raise equal protection problems. In some states, judges with restricted geographical jurisdiction are appointed by the state government; ${ }^{331}$ in other states, they are elected by voters within their jurisdictions. ${ }^{332}$ In either case, the judges are part of the state hierarchy, supervised and guided in their legal rulings by judges with statewide jurisdiction. ${ }^{333}$ Random errors by particular judges do not raise equal protection problems. ${ }^{334}$

ment cases teach that the concurrence of a local majority is insufficient to justify dilution of the community's vote. See Lucas v. Forty-Fourth Colo. Gen. Assembly, 377 U.S. 713, 731-36 (1964). The Supreme Court has frequently asserted that, although offices need not be made elective, once elections are permitted they must conform to the one-person, one-vote principle. See Rivera-Rodriguez v. Popular Democratic Party, 457 U.S. 1 (1982); Kramer v. Union Free School Dist., 395 U.S. 621 (1969). That is, the state could have appointed a governor, see Fortson v. Morris, 385 U.S. 231 (1966), and a city could choose to have an appointed mayor, $c f$. Sailors v. Board of Educ., 387 U.S. 105 (1967) (upholding appointment of county school board members by representatives from constituent school boards), presumably even if all the other cities in the state elected their mayors; but a state could not permit a municipality to close its polling places and exclude its residents from participation in the otherwise statewide election of a governor. Thus, the right to vote in statewide elections has an unusual status. It is unclear, however, whether this should be regarded as a replicable phenomenon of equal protection law, or as part of the substantive analysis of the right to vote, comparable to the uniformity clauses discussed above. See cases cited supra note 70 . The difficulty is compounded by the Court's identification of voting rights as purely an equal protection phenomenon.

sso As I have argued above, although the adoption of different regulations may serve a valuable role in tailoring state policy to local conditions through decentralized administration, these regulations are no more immune from equal protection scrutiny than discriminations among various industries or any other useful administrative classification. Decentralized administration through regional offices appointed and supervised by the state government is not a form of local self-determination justifying lesser equal protection scrutiny.

${ }^{3 s 1}$ See, e.g., Mass. ANN. Laws ch. 218, §§ 1, 6 (Law Co-op. 1986).

ss2 See, e.g., N.Y. CounTY LAW § 400(1) (McKinney 1972); see also Champagne, Selection and Retention of Judges in Texas, 40 Sw. L.J. (Special Issue), 53, 59 table 1 (1986) (listing state selection systems). See generally L. BERKSON, S. BELLER, \& M. Grimaldi, Judicial Selection in the United States: A Compendium of Provisions (1981) [hereinafter L. Berkson].

${ }^{3 s 3}$ See generally Hopkins, The Role of an Intermediate Appellate Court, 41 BROOKLYN L. REV. 459 (1975).

ss4 See Beck v. Washington, 369 U.S. 541, 554-55 (1962); Snowdon v. Hughes, 
But intermediate courts of appeals for different regions may systematically adopt independent answers to a question of state law through precedent. I will call these "circuit conflicts" by analogy with the same phenomenon in the federal courts. The effect of these circuit conflicts is to some extent the creation of local rules of law, ${ }^{335}$ but it is local law imposed on the community by a portion of the state judicial hierarchy, not law chosen by the community for itself.

The Supreme Court, citing the old formula of Missouri $v$. Lewis, ${ }^{338}$ has dismissed the notion that a state circuit conflict can create an equal protection violation. ${ }^{387}$ Though failure to resolve circuit conflicts might be defended as minimally rational, the Court's conclusion appears untenable in the context of fundamental rights discriminations. If a state structures its judicial system so that fundamental rights can vary from district to district because of unresolved disagreements between the respective courts, the resulting discrimination must be treated as if it were directly imposed by the state. Because the variation is not caused by a process of local self-determination, the discrimination will not be excused from heightened scrutiny. This does not mean that the conflict will inevitably be condemned as unconstitutional: the state will still have an opportunity to demonstrate its necessity, either by a showing that the discrimination is justified by a compelling difference in local conditions or by showing that the state's failure to resolve the conflict is itself justified by a compelling need. ${ }^{338}$ Moreover, the Supreme

321 U.S. 1,8 (1944).

s38 The legal system does not treat state circuit conflicts as a true form of local law, as is evidenced by the fact that the courts of the same hierarchy apply their own precedents rather than perceiving cases that might be thought to arise in another "jurisdiction" as requiring the application of conflict of laws principles. See, e.g., Friendly, "The Law of the Circuit" and All That, 46 ST. JoHN's L. REv. 406, $412-13$ (1972).; cf. Marcus, Conflicts Among Circuits and Transfers within the Federal Judicial System, 93 YALE L.J. 677, 702-08 (1984) (suggesting that both federal and state courts must review the merits of federal cases that come before them and not simply accept the interpretation of either another circuit or the federal courts); Note, Using Choice of Law Rules to Make Intercircuit Conflicts Tolerable, 59 N.Y.U. L. REv. 1078, 109198 (1985) (proposing artificial choice of law systems to eliminate forum shopping effect of circuit conflicts). I do not mean to rule out the possibility that a judicial system could be created in which locally elected subordinate judges exercised their discretion to create bodies of local law responsive to their local electorates in such a way as to justify treating the system as one of self-determination.

s36 101 U.S. 22 (1880).

397 See Ohio ex rel. Bryant v. Akron Metro. Park Dist., 281 U.S. 74, 81 (1930). sss Cf. United States v. Mendoza, 464 U.S. 154, 160 (1984) (discussing need for "exploration" of issues by the circuits to illuminate them for proper resolution by the Supreme Court); Estreicher \& Sexton, A Managerial Theory of the Supreme Court's Responsibilities: An Empirical Study, 59 N.Y.U. L. REv. 681, 716 (1984) (arguing that the Supreme Court need not resolve intercircuit conflicts when further "percolation" through the circuits is desirable). 
Court has found equal protection flexible enough to tolerate temporary inequalities where instantaneous adjustment is difficult, in both substantive and remedial contexts. ${ }^{339}$ Thus, short-term tolerance of circuit conflicts might withstand an equal protection challenge; however, longterm tolerance of circuit conflicts, resulting in substantial variations in the fundamental rights of the affected populations without a demonstrable justification in local conditions, normally will violate equal protection.

A similar analysis applies with equal strength to circuit conflicts in the federal courts. Such conflicts are an increasingly common problem, and the Supreme Court has shown a surprising degree of tolerance for them. ${ }^{340}$ Federal circuit conflicts, however, are hardly a salutary form of local self-determination. Federal circuit judges represent the regions over which they are appointed in only the remotest sense. ${ }^{341}$ Where persistent circuit conflicts, whether involving issues of statutory construction implicating fundamental rights or involving the interpretation of those rights themselves, lead to substantial regional disparities in the scope of fundamental rights, the Supreme Court has a constitutional obligation under the due process clause of the fifth amendment to intervene and resolve the conflicts. ${ }^{342}$

Conflicting decisions of state supreme courts regarding fundamental rights may not be under the same equal protection cloud. Naturally,

ss9 See, e.g., Reynolds v. Sims, 377 U.S. 533, 583-84 (1964) (state apportionment need not be updated annually); Heckler v. Mathews, 465 U.S. 728, 748 (1984) (reliance interest justifies temporary gender distinction in computation of social security benefits); Brown v. Board of Educ., 349 U.S. 294, 301 (1955) (school desegregation must be carried out with "all deliberate speed").

310 See, e.g., United States v. Stauffer Chemical Co., 464 U.S. 165, 174 (1984) (declining to address the issue of whether the application of collateral estoppel to the EPA will require it to apply different rules to persons similarly situated because of circuit splits on the substantive law); Mendoza, 464 U.S. 154 (1984) (finding that nonmutual collateral estoppel does not apply to the government because the desirability of percolating an issue outweighs that of intercircuit uniformity); Stauffer,464 U.S. at 178-79 (White, J., concurring) (arguing against extending preclusion to circuits that have adopted a contrary rule on the merits). Justice White has filed many dissents from denials of certiorari based on the Court's failure to resolve circuit conflicts. For an early example from the current term, see County of Wayne v. Carroll, 107 S. Ct. 330 (1986).

s41 See L. BERKSON, supra note 332, at 7-8.

342 The constitutionality of tolerating state "circuit conflicts" on issues of state law affecting fundamental rights can be litigated in federal court on habeas corpus or on direct review because the federal courts have authority to confront the constitutional issue but not to resolve the conflict by choosing the "correct" state law rule. See, e.g., Ohio ex rel. Bryant v. Akron Metro. Park Dist., 281 U.S. 74, 80-81 (1930) (holding that the Constitution does not require the states to adopt a unifying method of appeals). It would probably take a peculiar procedural posture to induce the Supreme Court to rule on the constitutionality of federal circuit conflicts, given that the Court always has the option of resolving the conflict in the case before it. 
state supreme court decisions concerning comparable state law issues can vary from state to state-such interstate variations represent exercises of federalism that do not implicate the equal protection clause. But even conflicts between state supreme courts on issues of federal law probably do not raise equal protection concerns. This problem will typically arise where two state supreme courts differ on the interpretation of a federal fundamental right in a context where the United States Supreme Court has given no final answer. ${ }^{343}$ The suspected equal protection defect might be characterized in one of three ways: the more restrictive court's action could violate the equal protection clause of the fourteenth amendment; the concurrent actions of the two courts taken together could constitute federal action violating the equal protection principles inherent in the due process clause of the fifth amendment; or the failure of the federal government to resolve the conflict could itself violate the due process clause. A holding of unconstitutionality based on any of these theories would be surprising. First, the equal protection clause of the fourteenth amendment will not be offended by such a conflict so long as that clause continues to be interpreted, as it has been, as addressing only discriminatory actions taken by a single state. A state supreme court resolving an open issue of federal statutory or constitutional interpretation differently than another state resolves it does not thereby "deny to any person within its jurisdiction the equal protection of the laws." Second, state courts adjudicating federal issues have not traditionally been regarded as federal courts, ${ }^{344}$ or otherwise as federal actors that must comply with the provisions of the Bill of Rights. ${ }^{\mathbf{9 4 5}}$

Thus, this line of analysis suggests that, if a conflict between state courts creates an equal protection problem, it must be because the federal government has failed in its obligations under the due process clause by not providing sufficient machinery for the resolution of disagreements about federal rights arising among the states. If this disparity is cognizable as a fundamental rights equal protection question,

s43 If the Supreme Court has ruled on an issue, the state court is obliged to follow it. See Oregon v. Hass, 420 U.S. 714, 719-20 n.4 (1975); Cooper v. Aaron, 358 U.S. 1, 18 (1958).

s44 See, e.g., Stone v. Powell, 428 U.S. 465, 482-83, 493 n.35 (1976); Younger v. Harris, 401 U.S. 37, 44 (1971).

${ }_{345}$ See Minneapolis \& St. L.R.R. v. Bombolis, 241 U.S. 211, 221 (1916); Cohens v. Virginia, 19 U.S. (6 Wheat.) 264, 421-22 (1821). The supremacy clause has been thought to bind state judges deciding federal questions in their capacity as state court judges, and the limits on their procedures come from federal statutes, federal common law, or the fourteenth amendment. See Dice v. Akron, C. \& Y.R.R., 342 U.S. 359, 361 (1952); Chicago, M. \& St. P. Ry. v. Minnesota, 134 U.S. 418, 456-57 (1890); Burbank, Interjurisdictional Preclusion, Full Faith and Credit and Federal Common Law: A General Approach, 71 CoRnell L. Rev. 733, 763 (1986); Meltzer, State Court Forfeitures of Federal Rights, 99 HARv. L. REv. 1128, 1131-32 (1986). 
then even on the assumption that the more restrictive interpretation is the "correct" one, litigants facing that interpretation are denied equal protection until some federal court overturns the more generous interpretation. This too would be a surprising analysis. ${ }^{346}$ State supreme court judges, unlike federal circuit judges, are chosen by the state in a process of territorial self-determination. ${ }^{\mathbf{3 4 7}}$ Because variations in the quality (or qualities) of state court judges will reflect state preferences, it is difficult to see why a litigant in a state court astute enough to give the federal Constitution a correctly narrow interpretation has a right to complain that the federal government has failed to suppress more generous interpretations in the courts of other states.

If the foregoing suggestions are correct, then they shed an unusual light on some recent controversies over the Supreme Court's exercise of its certiorari jurisdiction. From the equal protection point of view, the Supreme Court should be more concerned about circuit conflicts in the federal courts and could afford to spend less time overturning state court decisions favorable to federal constitutional rights. ${ }^{348}$

In summary, intrastate discriminations that track political boundary lines should be excused from heightened scrutiny only when they afford the affected communities equivalent opportunities for the exercise of local self-determination. Appropriately drafted local option laws can have this characteristic. The usual forms of special legislation, as well as their administrative and judicial counterparts, including "circuit

${ }^{348}$ One might face procedural problems in getting the equal protection issue into federal court. $C f$. supra note 342 . If the Supreme Court denies direct review in a civil case, principles of res judicata would keep the equal protection claims out of federal court. See Allen v. McCurry, 449 U.S. 90, 95 (1980). A criminal defendant, however, could raise the equal protection claim in federal court on habeas corpus. See 28 U.S.C. $\S 2254$ (1982).

s47 Whether directly elected or appointed by elected officials, state supreme court judges serve important functions of state self-determination as expositors of state constitutional law, state common law, and state statutory interpretation, as well as exercising what discretion they have in cases involving federal law. The effectiveness of federal judge selection as a means of self-determination in the context of federal constitutional law is a recurrent subject of debate. Compare Rehnquist, Presidential Appointments to the Supreme Court, 2 Const. CommenTARY 319, 328-30 (1985) (arguing that judicial direction is mostly independent of the President and popular will) with L. TRIBE, GoD Save This Honorable Courr 132-34 (1985) (arguing that the citizenry has the potential to affect judicial direction by means of election of President and Senate).

348 See, e.g., Michigan v. Long, 463 U.S. 1032 (1983) (expanding the Court's exercise of review of ambiguous state decisions favorable to federal claimants); Florida v. Meyers, 466 U.S. 380 (1984) (Stevens, J., dissenting) (criticizing the Court's readiness to review state court decisions favorable to federal constitutional rights); Estreicher \& Sexton, supra note 338, at 722-28, 740-41; see also Wallace, The Nature and Extent of Intercircuit Conflicts: A Solution Needed for a Mountain or a Molehill, 71 CALIF. L. Rev. 913, 917-19 (1983) (supremacy of federal law more important than uniformity of decisions). 
conflicts," do not share this characteristic and should trigger heightened scrutiny when they impose discriminations affecting fundamental rights.

\section{Fourth Special Position-Federal Discrimination Along State Boundary Lines}

The federal-state relationship is both like and unlike the state-city relationship. In material terms, the states are geographical subregions within the federal domain, and in most situations the federal government has the power to work its will on them. Yet in other respects the federal role is more analogous to the city's role: in principle the federal government possesses only delegated powers, and it legislates interstitially against the background of the corpus juris generated by the plenary lawmaking power of the states. ${ }^{340}$ Territorial discrimination by the federal government therefore requires separate investigation.

\section{a. Types of Federal Discrimination}

Federal geographical distinctions that cut across political boundary lines raise no special problems. They are like the "random intrastate variations" discussed in Part 3 above. Federal legislation governing only in certain kinds of terrain ${ }^{350}$ or only west of a given meridian ${ }^{351}$ imposes a federally crafted discrimination. If such legislation affects fundamental rights, it should be subjected to the same heightened equal protection scrutiny under the due process clause as would nongeographical discriminations with comparable impact.

Frequently, federal law varies from state to state. Sometimes Congress enacts particular rules expressly pursuing divergent policy in named states. ${ }^{.52}$ At other times, Congress identifies undesirable conditions and imposes special rules on those states where the conditions exist. ${ }^{353}$ More frequently, federal law varies because varying state law has been adopted as federal. I will refer to these as federal "incorpora-

340 See Wallis v. Pan Am. Petroleum Co., 384 U.S. 63, 68 (1966).

sso See Hodel v. Indiana, 452 U.S. 314 (1981).

ss1 See United States v. Tulare Lake Canal Co., 677 F.2d 713 (9th Cir. 1982), vacated as moot, 459 U.S. 1095 (1983).

${ }_{382}$ See, e.g., 12 U.S.C. $\S 1713$ (c)(2) (1982) (statutory limits on mortgage insurance inapplicable to Alaska); 30 U.S.C. $\$ 171$ (1982) (restriction on disposal of federal land in Alabama); 38 U.S.C. $\$ 601(4)$ (c) (1982) (provisions for veterans' health care in Alaska and Hawaii); 42 U.S.C. $\S 418$ (d)(6)(G) (1982) (special treatment of state retirement programs in seven named states).

${ }^{388}$ See, e.g., South Carolina v. Katzenbach, 383 U.S. 301,328 (1966) (provisions of Voting Rights Act of 1965 aimed at states "where voting discrimination [had] been most flagrant'). 
tion" cases. ${ }^{354}$ For example, some ventures in cooperative regulatory federalism allow the states to choose to displace the federal program by implementing similar programs. of their own. ${ }^{355}$ Moreover, the federal government has long used its power over interstate commerce to support state law enforcement efforts by imposing federal sanctions for interstate conduct leading to consequences unlawful under state law. ${ }^{356}$ Many federal statutes, expressly or by judicial construction, incorporate elements of local property, family, tort, or procedural law that varies from state to state. ${ }^{957}$ Assimilative crimes legislation allows federal crimes on federal territory within state boundaries to be defined by state criminal law. ${ }^{\mathbf{3 8 8}}$

Incorporation serves several federal policies. First, some instances may be justified by simple convenience. For much of our history, the legislative output of Congress was quite meager compared to the common law and legislation of the states. Adopting state law even in areas wholly beyond state power, such as federal court procedure and federal criminal jurisdiction, relieved the federal government of a significant lawmaking burden. ${ }^{389}$ Second, incorporation of state law may better effectuate federal policy by tailoring its implementation to local conditions. Reliance on definitions from state natural resources law, for example, may suit federal rules to varying climate conditions. ${ }^{380}$ Third,

384 I will use the term "incorporation" more broadly than is usual, including those instances where Congress permits federal law to be displaced by state law (which therefore remains state law while federal law on the relevant issue ceases to exist in the state), as well as instances where federal law absorbs rules of state law origin, thereby making them federal rules. See P. Bator, P. Mishkin, D. Shapiro \& H. WeChsLer, Hart \& Wechsler's The Federal Courts and the Federal System 767-68 (2d ed. 1973).

sss See, e.g., F.E.R.C. v. Mississippi, 456 U.S. 742, 771 (1982); Hodel v. Virginia Surface Mining \& Reclamation Ass'n, 452 U.S. 264, 271-72, 290 (1981); Steward Machine Co. v. Davis, 301 U.S. 548, 574 (1937).

sse See Clark Distilling Co. v. Western Md. Ry. Co., 242 U.S. 311, 325-27 (1917) (federal statute permitting state prohibitions on liquor to apply to movements of liquor in interstate commerce); 18 U.S.C. § 1952 (1982 \& Supp. III 1985) (Travel Act); 18 U.S.C. \$ 1962 (1982) (RICO).

s87 See, e.g., Andrus v. Charlestone Stone Prods., 436 U.S. 604, 614 (1978) (preservation of state law on ownership of water); Reconstruction Fin. Corp. v. Beaver County, 328 U.S. 204, 210 (1946) (RFC Act definition of "real property"); 17 U.S.C. $\S 101$ (1982) (Copyright Act definition of "widow"); 28 U.S.C. § 1346(b) (1982) (Federal Tort Glaims Act).

ss8 See Assimilative Crimes Act, 18 U.S.G. § 13 (1982); see also United States v. Sharpnack, 355 U.S. 286, 286 (1958) (upholding an earlier version of the Act).

s69 While debating the first assimilative crimes legislation, Representative Daniel Webster noted that: "The committee [of Congress] did not suppose it incumbent on them to enter into the details of a complete code of penal laws for a few hundred of the people in the United States' dock yards and arsenals." 1 Cong. Deb. 338 (1825).

s60 See California Or. Power Co. v. Beaver Portland Cement, 295 U.S. 142, 15455 (1935). 
adopting state law minimizes the frustration of federal policy by the conflicting behavioral incentives that would result from incongruent state and federal rules. ${ }^{361}$

The policy coordination is not, however, a one-way street. Federal incorporation of state law often reinforces state policy. Making the same acts unlawful in federal enclaves as elsewhere in the state protects the state citizenry from conduct it has identified as antisocial. ${ }^{\mathbf{3 6 2}}$ Incorporating state rules of succession helps the state protect those family members whose needs the state has chosen to emphasize. ${ }^{363}$ Cooperation may even take the form of an explicit local option for direct state modification of federal law. ${ }^{964}$ At the least, borrowing of state law elements can make federal law more easily understood by local citizens and practitioners.

It would be a mistake to characterize incorporation of state law as invariably furthering the state's immediate preferences. Federal income taxation of married couples provides a celebrated counterexample. ${ }^{385}$ Prior to 1948 , federal tax policy followed state marital property law to its logical conclusion by dividing community property income between the spouses in community property states while allocating all income to the earning spouse in common law states. ${ }^{368}$ Because the tax rates were progressive, the common law states experienced this incorporation as an unwanted increase in federal tax burdens. Several states adopted community property laws simply to diminish their contributions to the federal revenue. ${ }^{367}$ When Congress made available the uniformizing option of the joint return, these new community property states promptly

s61 See California v. United States, 438 U.S. 645, 668-69 (1978).

s82 See Sharpnack, 355 U.S. at 293-94 (1958); Note, The Federal Assimilative Crimes Act, 70 HARv. L. REv. 685, 689 (1957).

${ }^{\text {s6s }}$ See, e.g., DeSylva v. Ballentine, 351 U.S. 570, 580-82 (1956) (adopting state law definition of children for succèssion to copyright renewal rights); Seaboard Airline Ry. v. Kenny, 240 U.S. 489, 493-94 (1916) (adopting state law definition of next of kin in wrongful death action).

ses See, e.g., 42 U.S.C. $\S 7543$ (b) (1982) (allowing states that regulated auto emissions before March 30, 1966 to continue such regulation if necessary to meet "compelling and extraordinary conditions," and deeming compliance with state standard to be in compliance with federal law).

${ }^{365}$ See e.g., Bittker, Federal Income Taxation and the Family, 27 STAN. L. REv. $1389,1404-14$ (1975).

${ }^{368}$ See id. at 1404-14. Federal tax law did not, however, permit couples to evade the consequences of the initial assignment of income by adopting enforceable but consensual income splitting devices, even when these were denominated optional community property systems under state law. Rather, federal tax law bowed only to community property schemes "dictated by State policy, as an incident of matrimony." Commissioner v. Harmon, 323 U.S. 44, 48 (1944).

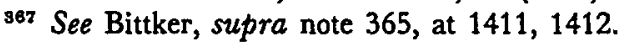


reverted to the common law system. ${ }^{368}$ Thus, federal "deference" to state marital property definitions inadvertently disrupted the domestic policy of those states that were willing to let the tail of taxation wag the dog of marital property law. Nonetheless, the original federal approach had bowed to state policy by taxing income to the party whom the state chose to recognize as its initial recipient. Congress was just more consistent in carrying out that policy than common law states competing fiscally with community property states wanted it to be.

Some instances of federal adoption of state law may be explained primarily as serving federal convenience. For example, the federal courts' practice of borrowing state statutes of limitations but using their own rules of laches and tolling seems better explained by judicial embarrassment at setting an arbitrary time limit than by the rhetoric of deference to state policies of repose. ${ }^{380}$ Still, identifying the relative strengths of the interests underlying a given federal incorporation of state law is rarely easy.

Unquestionably, federal incorporation of state law can create disparities in opportunities for the exercise of fundamental rights. For example, in 1911 the Supreme Court held that the federal Assimilative Crimes Act made the legality of circulating a newspaper article in a federal post office turn on the criminal libel law (if any) of the surrounding state. ${ }^{370}$ If Congress were to pass a statute requiring judicial approval when a minor seeks an abortion without parental consent, tied to a state law benchmark like the minimum age for valid marriage, ${ }^{371}$ the rights of young women would be burdened unequally in different states.

Sometimes the incorporation of state law into federal action does not create a new disparity, but simply translates to the federal level a contrast already inherent in the juxtaposition of the laws of the different states. The assimilative crimes example is of that kind: variations in the libel law applicable in federal enclaves in New York and New Jersey merely reflect the difference in governing in the rest of New York and New Jersey. A uniform federal rule would create a discrimination between the opportunities within and without federal enclaves, while assimilation creates a discrimination between federal enclaves in different states. In practical terms, this makes some kind of discrimina-

ses See id. at 1414.

sos See, e.g., Burbank, supra note 345 , at 769 .

s7o See United States v. Press Publishing Co., 219 U.S. 1, 14-16 (1911). Worse still, President Roosevelt was one of the alleged victims of the libel. See id. at 3.

s71 Cf. Bellotti v. Baird, 443 U.S. 622, 647-48 (1979) (striking down state statute requiring parental consent before abortion can be performed on unmarried woman under 18 because no alternative consent procedure provided). 
tion inevitable, but in theoretical terms the two discriminations cannot be equated: the former discrimination is the natural result of the Constitution's allocation of different spheres of authority to Congress and to the states, while the latter discrimination is a form of divergent action taken by the federal government itself.

In other instances, the disparity caused by federal incorporation of state law goes beyond the existing disparity among state laws. The abortion example just given illustrates this phenomenon. There an element of state law not linked to a particular fundamental right by the state itself is adopted into federal law to fill in the details of a scheme addressing that fundamental right. Even in practical terms, this incorporation creates new discriminations regarding the exercise of fundamental rights.

Thus, federal discrimination between states can affect fundamental rights, whether Congress acts by specifying different rules for different states or by impartially incorporating state law. The incorporation practice, however, exhibits a characteristic that by now should be familiar to the reader: borrowing state law can effectuate the local policy judgments of state electorates, thereby furthering the constitutional goal of state self-government. No such benefit is created when Congress directly imposes differing rules on various states, whether they are identified by name or operationally described. ${ }^{372}$ Does the value of comity in the incorporation situation justify less rigorous scrutiny of the resulting disparities?

\section{b. Virtues of Federal Incorporation}

Our system of federalism historically has rested upon the activity of state governments as the primary authors of the family, property, tort, contract, and criminal law that shape social interaction. For example, marriage, separation, divorce, paternity, legitimation, custody rights, emancipation, and majority are all defined by state family law. The federal government needs to employ some form of these concepts in administering such programs as immigration, social security, veterans' benefits, and copyright. ${ }^{373}$ Congress could generate uniform federal law

s72 The case against deferential scrutiny of discriminations of the kind mentioned is even stronger than the case against such scrutiny of special legislation at the state level because the United States Constitution itself presupposes and even guarantees the existence of the machinery for self-government in the states. See U.S. CoNST. art. IV, $\S 4$; U.S. CoNST. amend. X.

s73 See, e.g., 8 U.S.C. $\S 1101$ (b)(1) (1982) (definition of child for immigration purposes); 42 U.S.C. $\$ \S 101(3),(4)$ (1982) (definition of surviving spouse and child for purposes of veterans' benefits). 
to govern these questions, but inevitably it would conflict with the rules chosen by some state-Congress would be requiring an individual to share some benefit with a "spouse" or "child" not recognized as a spouse or child under state law. Such rulings would undermine the states' traditional role in defining the conditions under which family obligations are created or extinguished. ${ }^{374}$ Alternatively, the federal government can incorporate state law, effectuating federal policies while accommodating them to local policy judgments that refine but do not frustrate the federal purpose.

I would not make the strong claim that tolerance for the disuniformity that results from federal incorporation of state law is necessary to permit state self-government. The areas of state lawmaking into which the federal government has not intruded are still large, and the Supreme Court has made the obligation of the federal courts to apply state law in the exercise of diversity and pendent jurisdiction much stronger than the full faith and credit obligations of state courts. ${ }^{\mathbf{3 7 5}}$

Rather, federal incorporation of state law minimizes federal incursions on state self-government and in some instances extends the reach of policymaking by interested states into spheres that the Constitution assigns initially to federal authority, like interstate commerce, immigration, and federal enclaves. ${ }^{378}$ Federal incorporation facilitates state selfgovernment, even though state autonomy would not be impossible without it.

The parallels between federal incorporation of state law and state employment of a sister state's law through dépaçage should be evident. In both cases, borrowing can accord comity to the policy judgments made by the lending state in designing the borrowed rule. Both represent accommodations to the overlapping spheres of authority that sovereigns inhabit in our federal system. There is, however, one important difference: the dangers of parochial discrimination inherent in state-to-state choice of law decisions do not infect the federal incorpora-

s74 Sometimes Congress chooses to do this. See, e.g., 17 U.S.C. $\$ 101$ (1982) (adopting federal definition of "children" for purposes of Copyright Act). I do not address the question whether Congress could reverse the traditional roles of state and federal law and preempt state power to define family relationships and obligations altogether.

375 See Erie R.R. Co. v. Tompkins, 304 U.S. 64 (1938). Compare Guaranty Trust Co. v. York, 326 U.S. 99, 105 (1945) (federal court must apply state statute of limitations in diversity case) with Wells v. Simonds Abrasive Co., 345 U.S. 514, 523 (1953) (forum state may apply its own statute of limitations).

${ }_{378}$ The Supreme Court has upheld the resulting extensions of state power against claims of unlawful delegation. See, e.g., United States v. Sharpnack, 355 U.S. 286, 29394 (1958) (federal enclaves); Clark Distilling Co. v. Western Md. Ry. Co., 242 U.S. 311, 330-32 (1917) (interstate commerce). But see Knickerbocker Ice Co. v. Stewart, 253 U.S. 149, 159, 161 (1920) (forbidding such delegation in admiralty). 
tion practice. When a state applies foreign law to nonresidents, it may be denying them benefits of its own law that it reserves for its own citizens. But when the federal government adopts state law, it is not denying the citizens of the states some benefit selfishly reserved for another, more favored group. Either there is no federal rule, ${ }^{377}$ or the federal government has given the states themselves the option of displacing it. ${ }^{378}$ In this situation there is no favored group because the members of Congress all represent the states. ${ }^{379}$

Because parochial discrimination does not underlie federal incorporation of state law, we need not be as suspicious of incorporation as I argued we should be of discriminations in state choice of law. There is less danger, for example, that a state's rules will be lifted out of context and applied against its residents in order to disadvantage them. On the other hand, federal incorporation of state law does more than just preserve variations in state fundamental rights-it transposes them to the national level and can extend the inequalities to spheres that the state has no power to reach on its own. In addition, the degree to which the sacrifice of uniformity results from deliberate federal deference to local policy, rather than from congressional indifference and laziness, will be unclear in particular cases.

The equal protection problem arises when less favorable incorporated state law disadvantages a litigant (who may or may not be a resident of the enacting state), and she points to a more favorable rule that federal law incorporates in another state. The unfavorable rule will usually not be absolutely necessary to achieve the underlying federal interest, or Congress would not have incorporated the more favorable rule in another state. Furthermore, in most cases, the federal interest in deferring to state policy will have been inconsistently asserted. ${ }^{380}$ In-

s77 This is usually the reality in the cases conventionally denominated "incorporation." See supra note 354 and accompanying text. Sometimes the federal courts reserve the right to reject state law that is repugnant to federal policy. I will discuss this issue infra at text accompanying note 384 .

s78 This is the case in some situations that I have also included under the label "incorporation." See supra note 355 and accompanying text.

${ }^{379}$ See, e.g., Garcia v. San Antonio Metro. Transit Auth., 469 U.S. 528, 547-55 (1985); $c f$. Frazier v. Heebe, 788 F.2d 1049, 1053 (5th Cir. 1986) (upholding district court ruling denying bar admission to attorneys who do not reside in or maintain an office in the state) ("As a citizen, insofar as federal actions are concerned he is not an outsider lacking political power, as that concept is understood in the equal protection analysis."), cert. granted, 55 U.S.L.W. 3357 (U.S. Nov. 17, 1986) (No. 86-475). I put to one side for the moment the paranoid suggestion that incorporation of state law is a plot to discriminate in favor of the residents of the District of Columbia. We will return to them later.

s80 See, e.g., Note, supra note 362, at 691-96 (discussing exceptions to incorporation of state law under the Assimilative Crimes Act). 
deed, if Congress were that concerned about state choices, it could have turned control of the subject over to the states rather than incorporating portions of their laws. No doubt some incorporations of state law could run the gauntlet of these objections and still survive strict scrutiny, but the federal government's various compromises with state policymaking will rarely be defensible under a compelling interest standard.

Rigid application of equal protection principles would suggest that the federal government should be required to adopt uniform federal rules in all instances where fundamental rights are substantially affected and incorporation of state law is not strictly necessary. I believe, however, that there is constitutional value in preserving the interstitial character of federal legislation, and affording room for a range of compromises between state and federal policy. Federal incorporation of state law may amplify diversity, but it does not create diversity where none yet exists. The independent sovereignty of the states generates that diversity, and the differences reflect democratic policy choices of the citizens of the various states. Disparities will occur only to the extent that local choices create them. These choices will have their greatest impact on the populations making the choice, and divergences from uniformity may as often increase the scope for exercise of fundamental rights as decrease it. Restraint by the federal government in displacing these policy choices furthers the constitutional goals of political participation and of federalism itself. Though the need is less poignant than in the prior examples, ${ }^{381}$ federal incorporation of state law should be made possible by excusing the resulting geographical variations from heightened equal protection scrutiny under the due process clause. ${ }^{382}$

One additional peculiarity of federal incorporation practice should be mentioned. Federal statutes sometimes set out a presumptively applicable federal rule and then allow state law to take its place only to the extent that the state rule is stricter than the federal one. ${ }^{\mathbf{8 3}}$ Similarly, the methodology of federal common law incorporation of state law elements permits rejection of aberrant state rules that would frustrate the achievement of federal policy. ${ }^{384}$ In discussing state-to-state

s81 Those examples are: (1) municipal action affecting fundamental rights, where no self-government would be possible if heightened scrutiny applied, and (2)state choice of law, where internecine assertions of prescriptive jurisdiction undercutting self-government would be required if heightened scrutiny applied.

s82 This conclusion is rejected by Bernard Evans Harvith. See Harvith, Federal Equal Protection and Welfare Assistance, 31 ALB. L. REv. 210, 226 (1967); Harvith, The Constitutionality of Residence Tests for General and Categorical Assistance Programs, 54 CALIF. L. REV. 567, 637-40 (1966).

sss See, e.g., 42 U.S.C. $\$ 7543$ (motor vehicle emissions standards) (1982).

ss4 See, e.g., Burbank, supra note 345, at 812; Mishkin, The Variousness of "Federal Law": Competence and Discretion in the Choice of National and State 
choice of law problems, I pointed out the discriminatory potential of similar state law ratcheting principles, which would bias the process of adopting sister state law to the disadvantage of nonresidents. This danger is not present in the federal practice because the citizens of the states are not disenfranchised rivals of the federal government. Even this partial incorporation increases the local participation in self-government. Furthermore, the consequent disparities in fundamental rights will be of lesser magnitude than those resulting from unconditional incorporation of state law. But the selective practice of adopting state rules within a range acceptable to the federal government is particularly difficult to justify under a strict scrutiny standard. Thus, I would not carry over the strictures against selective choice of law in the stateto-state context. This mode of selective federal incorporation should also be excused from heightened scrutiny.

\section{c. Complication: The District of Columbia}

The pure model just described is complicated by the recognition that there is federal territory where no state law can reach. The problem of overseas territories has been vexing historically and exceeds my capabilities. $^{385}$ It will be enough for the present Article, I hope, to consider how the analysis is affected by including the District of Columbia.

I previously argued that federal incorporation cannot reflect parochial hostility against citizens of the states because state citizens themselves elect all the voting members of Congress. No one could suspect Congress of a natural tendency to discriminate in favor of the District of Columbia and against the states, because the states but not the District are represented. ${ }^{386}$ We may be leery, however, of a possible motive for congressional discrimination against the District. ${ }^{387}$

The Constitution expressly assigns to Congress the power to "ex-

Rules for Decision, 105 U. PA. L. REv. 797, 804-06 (1957).

${ }^{388}$ See, e.g., Harris v. Rosario, 446 U.S. 651 (1980); Downes v. Bidwell, 182 U.S. 244 (1901); Leibowitz, United States Federalism: The States and the Territories, 28 AM. U.L. REv. 449 (1979); Cabranes, Puerto Rico: Colonialism as Constitutional Doctrine (Book Review), 100 Harv. L. Rev. 450 (1986) (reviewing J. Torruella, The Supreme Court and Puerto Rico: The Doctrine of Separate and UneQUAL (1985)).

386 The District does have a "delegate" in Congress, but no vote. See D.C. CoDE ANN. $\S 1-401$ (1981). Since 1961, the District also has been represented by three members in the electoral college. U.S. ConsT. amend. XXIII.

${ }^{887}$ As a ruling group accountable only to constituents who live elsewhere, convening in a city impoverished and overwhelmingly black, members of Congress may, for example, succumb to the temptation to adopt innovations in the criminal law that they would find unacceptable for their home districts. See, e.g., United States v. Thompson, 452 F.2d 1333, 1339 (D.C. Cir. 1971) (construing statute imposing more stringent bail procedures only in District of Columbia), cert. denied, 405 U.S. 998 (1972). 
ercise exclusive Legislation in all Cases whatsoever, over such District (not exceeding ten Miles square) as may, by Cession of particular States, and the Acceptance of Congress, become the Seat of the Government of the United States." peatedly that this clause authorizes Congress to pass the full range of legislation that the states can pass within their own borders. ${ }^{389}$ The Court has also pointed out the resulting dual character of congressional authority over the District: Congress acts both as a local legislature and as a national government. ${ }^{390}$

One might ask whether the power of "Legislation in all Cases whatsoever" comprehends the ability to enact laws that no state could enact and that simultaneously are beyond the powers granted to Congress in other clauses. The conventional answer is yes, for two reasons. First, some express guarantees of individual liberty against state action in the Constitution do not bind the federal government. ${ }^{391} \mathrm{~A}$ court might well conclude that Congress is as free of those limitations when legislating for the District as when legislating nationally. But more broadly, the Supreme Court has suggested that there are also powers beyond the sphere of state government, and yet otherwise unenumerated, that the seat of government clause authorizes Congress to exercise. ${ }^{392}$ Congress, in legislating for the District, acts as no "mere local legislature";"s8s rather, it acts for a purpose which is "national in the highest sense," and the supremacy clause provides Congress with means of accomplishing its goals that no state has. ${ }^{385}$

388 U.S. Const. art. I, $\S 8$, cl. 17.

389 See, e.g., Palmore v. United States, 411 U.S. 389, 397 (1973); Berman v. Parker, 348 U.S. 26, 31 (1954); Keller v. Potomac Elec. Power Co., 261 U.S. 428, 442-43 (1923); Gibbons v. District of Columbia, 116 U.S. 404, 407-08 (1886).

${ }^{390}$ See Palmore, 411 U.S. at 397; Keller, 261 U.S. at 443; Cohens v. Virginia, 19 U.S. (6 Wheat.) 264,427 (1821).

391 The contract clause is an example. See PBGG v. R.A. Gray \& Co., 467 U.S. 717, $732-34$ (1984). But see D.C. CoDE ANN. § 1-204 (1981) (subjecting D.C. local government to all limitations contained in art. I, $\S 10)$. Conversely, there are some clauses, like the seventh amendment, that bind Congress, and the District of Columbia, but not the states. See Pernell v. Southall Realty, 416 U.S. 363 (1974).

${ }^{302}$ Discussions of the reach of enumerated powers are necessarily embarrassed by the fact that nearly any congressional action can be rationalized under the commerce clause. See Katzenbach v. McClung, 379 U.S. 294 (1964) (upholding Title II of the Civil Rights Act of 1964 on the basis of federal commerce power). But see Oregon v. Mitchell, 400 U.S. 112 (1970) (invalidating voting rights act amendments of 1970 with respect to state and local elections as beyond powers delegated to Congress).

${ }^{303}$ Cohens v. Virginia, 19 U.S. (6 Wheat.) 264, 427 (1821) (dictum).

894 National Mut. Ins. Co. v. Tidewater Transfer Co., 337 U.S. 582, 601 (1949) (plurality opinion of Jackson, Black, and Burton, J.J.); accord O'Donoghue v. United States, 289 U.S. 516, 538-39 (1933).

${ }^{303}$ See National Mut. Ins. Co., 337 U.S. at 600-02; Cohens, 19 U.S. at 427-29. 
The Supreme Court distinguishes among these aspects of Congress's power in considering the permissible scope of delegation of home rule authority to the District. The Court has upheld delegation of statelike local self-governing power to an elected District legislature, ${ }^{396}$ but it has also held that Congress could not similarly delegate its strictly national powers. ${ }^{397}$ Congress may transfer to a District government, as to a Territory, those "matters 'which, within the limits of a State, are regulated by the laws of the State only." "398

Thus Congress possesses three related categories of authority with respect to the District that serve three different constitutional purposes. First, as the national legislature, Congress has those tasks and powers within the District that it has throughout the United States. Second, because the States have resigned lawmaking authority over the District, someone must take their place. That task, with accompanying state-like powers, is assigned initially and ultimately to Congress. Third, because the federal government has unique interests in control of its capital, the Constitution grants it the broadest plenary authority, "in all Cases whatsoever, over such District." 889

This constitutional scheme leaves District residents with very truncated political rights. They are not represented in Congress, which has ultimate authority to enact their local laws. ${ }^{400}$ From time to time Congress has created elected local governments for the District, but it has limited their authority. ${ }^{401}$ The District now has its own local courts,

These intimations are rare; the extraordinary means approved include extension of diversity jurisdiction to citizens of the District, pledging the national credit for local borrowing, mixing legislative and article III jurisdiction, and compelling states to permit sale of District lottery tickets.

${ }^{308}$ See District of Columbia v. John R. Thompson Co., 346 U.S. 100, 106-10 (1953); $c f$. Mattingly v. District of Columbia, 97 U.S. 687 (1878) (upholding delegation of authority to revise and correct local assessments for public works projects). Indeed, James Madison relied upon the inevitable creation of a freely elected municipal legislature in the District as part of his defense of the seat of government clause. See The Federalist No. 43, at 310 (J. Madison) (B. Wright, ed. 1961). Congress has not, however, always kept this promise. See infra note 401.

sez See John R. Thompson Co., 346 U.S. at 106.

se8 Id. (quoting Simms v. Simms, 175 U.S. 162, 168 (1899)).

so9 U.S. ConsT. art. I, $\S 8$, cl. 17; see also THE FeDERALIST No. 43 , supra note 396, at 309:

The indispensable necessity of complete authority at the seat of government, carries its own evidence with it . ... [A] dependence of the members of the general government on the State comprehending the seat of the government, for protection in the exercise of their duty, might bring on the national councils an imputation of awe or influence....

400 The District does have a nonvoting delegate. See supra note 386.

401 See, e.g., District of Columbia Self-Government and Government Reorganization Act, Pub. L. No. 93-198, 87 Stat. 774 (1973) (current version at D.C. CoDE ANN. $\S \S 1-204,1-206,1-233,47-313$ (1981)). See generally Franchino, The Constitutional- 
but their judges are appointed by the President and serve only fifteenyear terms. ${ }^{402}$

Some have argued that the District's lack of representative government should entail heightened scrutiny of congressional legislation discriminating against the District. ${ }^{103}$ This seems at first glance to be a reasonable consequence of the "representation-reinforcing" theory of constitutional interpretation advocated by Dean Ely. ${ }^{404}$ Groups denied a full opportunity for political participation, like aliens, nonresidents, and members of racial minorities, deserve close judicial attention to laws that discriminate against them. ${ }^{405}$

But this argument proves far too much. The Constitution itself guarantees the states a republican form of government but assigns plenary power over the District to a body in which its residents are not represented. Treating District residents as a suspect class so long as they are not enfranchised would topple this constitutional structure. First, the purposes of the seat of government clause would be defeated if Congress were forbidden by the equal protection clause from enacting local legislation in the District merely because it lacked the power to enact it nationwide. ${ }^{408}$ Second, even where Congress's powers over-

ity of Home Rule and National Representation for the District of Columbia, 46 GEO. L.J. 207 (1958) (recounting the history of governance of the District from 1800 to 1924).

Under current law, the D.C. council has broad self-governing authority. See D.G. CODE ANN. $\$ \S 1-204,1-206,1-233,47-313$ (1981). Congress originally retained a one-house legislative veto over D.C. laws. See District of Columbia Self-Government and Government Reorganization Act, Pub. L. No. 93-198, § 602(c)(2), 87 Stat. 774, 814 (1973). After the one-house legislative veto fell in Immigration and Naturalization Serv. v. Chadha, 462 U.S. 919 (1983), this was changed to a veto by expedited joint resolution. See D.C. CoDE ANN. §§ 1-207, 1-233(c) (Supp. 1985).

${ }^{102}$ See D.C. CoDE ANN. $\S \S 11-1501,11-1592$ (1981).

${ }^{108}$ See, e.g., United States v. Greene, 489 F.2d 1145, 1165 n.28 (D.C. Gir. 1973) (Bazelon, C.J., dissenting from denial of rehearing en banc), cert. denied, 419 U.S. 1977 (1974); United States v. Thompson, 452 F.2d 1333, 1341 (D.C. Cir. 1971); $g f$. United States v. Cohen, 733 F.2d 128, 144-46 (D.C. Cir. 1984) (en banc) (Mikva, J., joined by Robinson, C.J., and Wright, J., concurring) (rejecting the theory that District residents are a "suspect class" within the meaning of the equal protection clause merely because they have no vote in congressional elections, but stating that "when Congress acts in its capacity as the national legislature, a separate and unequal legislative scheme for the District of Columbia ought to elicit some concern that invidious lines have been drawn precisely because of the national disenfranchisement of the groups affected by those lines."); Note, Federal and Local Jurisdiction in the District of Columbia, 92 YALE L.J. 292, 326 (1982) ("In view of the longstanding restriction upon the exercise by District residents of political rights . . . these classifications must be judged with particular scrutiny.") (footnotes omitted).

104 See J. ELY, supra note 46, at 83.

${ }^{406}$ See $i d$. at 83-84, 102-03, 161-62.

100 This is also an occasion for application of the principle discussed earlier, that distinctions required by the Constitution itself cannot violate equal protection. See supra note 233 and accompanying text. 
lapped sufficiently to permit nationwide extension of its legislation for the District, the Constitution's allocation of local sovereignty would be destroyed if Congress had to override state policy choices from coast to coast whenever it adopted a measure in the District. Thus, suspect class treatment for the District of Columbia is unworkable, and the Supreme Court's unreceptiveness to the approach is understandable. ${ }^{\mathbf{4 0 7}}$

Even if District residents cannot be treated as a suspect class, it could be argued that heightened scrutiny should protect them in some instances under the doctrine of fundamental rights equal protection. I argued earlier that a federal statute discriminating by name against a single state in a manner that substantially affected fundamental rights would rightly trigger heightened scrutiny. Does legislation applicable to the District but not the states deserve similar treatment?

Legislation enacted by an elected home rule government for the District would escape heightened scrutiny. The legislation would ultimately be attributable to Congress, ${ }^{408}$ but the same modification in equal protection methodology that preserves independent lawmaking by municipalities within the states would justify the discrimination. ${ }^{409}$ Otherwise, self-determination for the District would be impossible. True home rule would make the District virtually a fifty-first state, and the increase in diversity of rights would be the kind of diversity we encourage.

Congressional legislation for the District is not similarly justified as self-government. Indeed, Congress legislates for the District even less democratically than a state legislates for its capital, whose residents have at least some representation in the state legislature. But in most situations, congressional discrimination against the District is justified because of its contribution to self-government in the states. The District may not function as a state from its own citizens' point of view, but from the perspective of the citizens of the fifty states it does.

Consider the kinds of statutes Congress can enact for the District. Some are supported solely by Congress's state-like powers under the seat of government clause and could not be extended nationwide be-

407 See, e.g., Heald v. District of Columbia, 259 U.S. 114, 124 (1922) (rejecting "taxation without representation" challenge to taxing District residents); Loughborough v. Blake, 19 U.S. (5 Wheat.) 317, 320 (1820) (same); cf. Harris v. Rosario, 446 U.S. 651, 651-52 (1980) (disparate treatment of Puerto Rico in federal welfare legislation subject only to rational basis test).

${ }^{108}$ See also Welch v. Gook, 97 U.S. 541, 542 (1878) (treating legislation enacted by elected D.C. government as if enacted by Congress).

100 If, however, Congress enacted restrictive legislation in the states and did not extend it to the District, or gave the District but not the states, the option to lessen its impact on fundamental rights, then Congress's discrimination, not the District's, would trigger heightened scrutiny. 
cause Congress lacks authority to impose them on the states. Accordingly, any discrimination these cause with respect to fundamental rights does not violate equal protection. ${ }^{410}$

Many enactments can be supported either by Congress's state-like powers or by other enumerated powers like the commerce clause. ${ }^{411}$ When Congress adopts such a statute to serve local purposes in the District, it normally leaves the states free to decide whether to adopt more, less, or equally restrictive legislation in their own territory. Any resulting disparity in fundamental rights between the District and the States is then comparable to interstate variations inoffensive to the equal protection clause. Congress acts with territorial restraint, but it does so in order to preserve the policymaking prerogatives of the states within their own boundaries. This restraint furthers both interests in federalism and the facilitation of self-determination by the citizens of the states. ${ }^{42}$ Holding back the heavy federal hand so that local electorates can govern themselves once more justifies departure from uniform opportunities for the exercise of fundamental rights.

This same rationale justifies federal legislation that is applicable nationwide but imposes greater burdens on fundamental rights within the District than in the states, as long as Congress does not preempt the states' ability to equalize the burden. For example, if Congress, in the exercise of its power under the commerce clause to regulate medical practice, required parental notification when anyone under the age of fourteen sought an abortion, but raised the age to sixteen in the District, ${ }^{413}$ heightened scrutiny of the geographical disparity should not follow. Congress has effectively acted in two capacities-in its national capacity, it has decided that notification is needed at least when the patient is under fourteen and has left to the states as a matter of local policy whether to require notification for older teenagers as well. In its capacity as local policymaker for the District, Congress has decided that a higher age limit than the national minimum is appropriate. Though

$110 C f$. United States v. Antelope, 430 U.S. 641,649 (1977) (holding that federal law applicable to Indian reservations that significantly differs from the law of the surrounding state does not deny equal protection and stating that "[u]nder our federal system, the National Government does not violate equal protection when its own body of law is evenhanded, regardless of the laws of States with respect to the same subject matter") (citations omitted).

"11 Some enactments may be supported only by the seat of government clause in the District, but would be supportable by the enforcement provisions of the fourteenth amendment in the states.

412 Though not, alas, of the District of Columbia.

113 Cf. H.L. v. Matheson, 450 U.S. 398 (1981) (upholding a state statute requiring parental notification prior to performance of an abortion for an unemancipated minor female). 
there is a discrepancy in the treatment different individuals will receive from the federal government, that discrepancy reflects the different roles Congress performs in varying geographical locations. In Utah, Congress acts as enforcer of nationwide minimum standards that the state is free to surpass; in the District, Congress is the only government and must play both roles. So long as Congress leaves the states free to replicate the rule it chooses for the District, the inequalities serve to protect local choice.

Different conclusions result, however, when Congress prevents the states from following its lead. If Congress adopts more restrictive measures in the District and preempts the states from adopting similar measures in their own territory, or if Congress adopts a statute that burdens fundamental rights more heavily in the states than in the District, then Congress has not preserved the policymaking autonomy of the states. No interest in self-government is served by the discrimination, either in the District, which does not govern itself, or in the states, which Congress has blocked from doing so. The disparity is wholly of Congress's making and normal equal protection methods should apply.

Sometimes precise equalization of the burdens will be prevented, not by overt action of Congress, but by divergences between the constitutional powers of Congress and the states. Congress may pursue some of its local policy ends in the District using means that are not available to the states. This may be attributable to Congress's greater power under the necessary and proper clause, ${ }^{\mathbf{4 1 4}}$ or to the existence of a specific limit on state power that is not binding on Congress. ${ }^{\mathbf{1 1 6}}$ In either case, the state lacks the ability to implement a local policy exactly duplicating the scheme chosen by Congress for the District. ${ }^{118}$ But the state is still free to accept or reject as a local matter the policy with respect to fundamental rights that Congress has chosen. An opportunity for total duplication should not be necessary to escape the application of heightened scrutiny; the state's interest in self-government is still being preserved.

Finally, there may conceivably be cases where Congress exercises a national power for identifiably national purposes but limits the impact of the legislation to the District. For example, Congress might forbid citizens of the District from travelling to Nicaragua. ${ }^{\mathbf{4 1 7}}$ No state

114 See supra note 395 and accompanying text.

415 The contract clause is an example. See supra note 391.

416 To take a possibly trivial example, Congress has made the federal courts and federal law enforcement officers available for prosecution of crimes against the District but does not normally do so when the states decide to enact similar criminal statutes. See generally Note, supra note 362.

${ }_{117}$ Cf. Zemel v. Rusk, 381 U.S. 1 (1965) (upholding ban on travel to Cuba). 
could enact such a law without usurping federal authority over foreign commerce and foreign policy. ${ }^{418}$ Failure to extend the law to citizens of the states, therefore, cannot be characterized as deference to state selfgovernment, and thus heightened scrutiny is appropriate.

To sum up: to the extent that democratic home rule is exercised by the District, it should be able to create greater burdens on fundamental rights within its borders than federal law generally creates, without triggering heightened scrutiny, because the discrimination furthers selfgovernment both in the District and in the states. Congressional legislation for the District should also be able to create greater burdens on fundamental rights than Congress imposes in the states, without triggering heightened scrutiny, because the discrimination furthers self-determination by the states. But if Congress preempts the states from imposing similar burdens or imposes greater burdens in the states than in the District, no interest in self-government is served, and heightened scrutiny should still apply.

\section{The Framework APPLied}

Having sketched at length a method for evaluating claims of equal protection violations based on territorial discriminations affecting fundamental rights, I would like to illustrate its application in actual cases. Two dissimilar examples follow. The first involves discrimination between federal criminal defendants being tried in the District of Columbia and those being tried in the states. The second concerns the proper role of local government autonomy in educational finance.

\section{A. United States v. Cohen}

In 1980, one Jeffrey Cohen was arrested carrying three homemade bombs near the embassy of the People's Republic of China in Washington, D.C. Cohen was charged with possession of unregistered destructive devices in violation of 26 U.S.C. $\$ 5861$ (d), and tried in the United States District Court for the District of Columbia. The court found him not guilty by reason of insanity. ${ }^{\mathbf{1 1 9}}$

${ }^{418}$ See Zschernig v. Miller, 389 U.S. 429 (1968) (holding that Oregon law requiring escheat of estate where heir is citizen of nation with disfavored probate laws intruded upon federal authority in foreign affairs); United States v. Pink, 315 U.S. 203, 231 (1942) (holding that New York court's refusal to recognize Soviet nationalization of Russian assets where the United States had extended such recognition impaired federal foreign policy); Chy Lung v. Freeman, 92 U.S. 275, 280 (1875) (holding that California law giving state official discretion to prohibit aliens from entering country was beyond state's power).

419 See United States v. Cohen, 733 F.2d 128, 129 (D.C. Cir. 1984) (en banc). 
Had Cohen been tried for this offense in a federal district court anywhere else in the country, he would have been released. ${ }^{420}$ In federal court in the District of Columbia, however, a different procedure governed because Congress had created a separate scheme for the insanity defense in the District and applied it both in the local courts and in the federal courts. ${ }^{421}$ Pursuant to this system, Cohen was immediately committed to Saint Elizabeths Hospital, where he would remain until he could prove by a preponderance of the evidence that he was no longer mentally ill and dangerous. ${ }^{422}$ Cohen argued that this variation between the rights of federal insanity acquittees in the District of Columbia and the rights of federal insanity acquittees in the states denied him equal protection. ${ }^{423}$ How should an equal protection challenge like Cohen's be decided?

\section{Background on Commitment of Insanity Acquittees ${ }^{424}$}

Public fear and resentment of defendants who successfully assert the insanity defense has made their post-acquittal disposition a perennial subject of controversy. The moral premise purportedly underlying the defense is that mentally ill offenders cannot be "blamed" and should not be "punished" for their acts. ${ }^{48}$ The public demands, how-

420 See id. at 131 .

421 See id. at 130-31; D.G. Code ANN. \$24-301 (1981).

422 See Cohen, 733 F.2d at 129, 131.

423 Cohen deserves at least a footnote in history. A divided panel of the D.C. Circuit accepted his claim, thereby calling into doubt the separate congressional scheme governing the insanity defense in the federal courts of the District. Reportedly as a result of this decision, federal trial judges in the District began placing the burden of proof on the prosecution to demonstrate the sanity of criminal defendants beyond a reasonable doubt, the usual federal rule at the time, rather than requiring proof of insanity by a preponderance of the evidence, the standard Congress had legislated for the District. See Brief for the United States at 6 n.5, United States v. Jones, 463 U.S. 354 (1983) (No. 81-5195).

By an accident of timing, the district court employed this reasonable doubt standard in the trial of John W. Hinckley, Jr., for the attempted assassination of President Ronald Reagan. See id.; Note, Federal and Local Jurisdiction in the District of Columbia, 92 Y ALE L.J. 292-93 (1982). Hinckley's acquittal provided a focus for public dissatisfaction with the insanity defense. See, e.g., MODEL InSANITY Defense and Post-Trial Disposition ACT, Prefatory Note 11 U.L.A. 142-43 (Supp. 1986); Marguiles, The "Pandemonium Between the Mad and the Bad": Procedures for the Commitment and Release of Insanity Acquittees After Jones v. United States, 36 RUTGERS L. REv. 793, 793-94 \& n.3 (1984). This led to a substantial tightening of federal law on the subject, coincidentally sweeping away for the future the discrimination of which Cohen had complained.

434 This discussion is purely descriptive. Rather than critiquing the Supreme Gourt's constitutional analysis of issues relating to mental illness, I would like to assume its propriety and then sketch enough of the context to show how the issues change when territorial discrimination is involved.

125 See, e.g., Jones v. United States, 463 U.S. 354, 369 (1983) (dictum) (insanity 
ever, that acquittees not be left at liberty, and allegations of a "revolving door," permitting dangerous people to avoid confinement or to be released prematurely, are common. ${ }^{428}$ These fears are coupled with concern that clever criminals may feign insanity and escape justly deserved punishment. ${ }^{427}$ Proposals to eliminate the insanity defense or to confine successful defendants permanently for protection of the public therefore recur. ${ }^{428}$

Efforts to deprive acquitted defendants of their liberty must overcome modest barriers of due process and equal protection. At a minimum, confinement must serve a legitimate purpose and must be accompanied by appropriate procedural protections. But the Court's method for resolving constitutional claims in the mental health field is hard to pin down. It has consistently avoided open adoption of a fundamental rights or suspect class approach. ${ }^{429}$ Nonetheless, it has often held state action invalid, by employing low-level due process techniques, ${ }^{430}$ and a form of equal protection scrutiny that the Court misleadingly labels a rationality test. ${ }^{431}$

The cases sketch some of the constitutional parameters for invol-

defendant acquitted, not convicted, and therefore may not be punished); State v. Krol, 68 N.J. 236, 344 A.2d 289, 295 (1975) (acquittal by reason of insanity indicated lack of mens rea; therefore, no punishable crime was committed).

${ }^{20}$ See, e.g., Lynch v. Overholser, 369 U.S. 705, 715 (1962) (dictum) (fear of "flood of acquittals" and immediate release of criminally insane); United States v. Cohen, 733 F.2d 128, 130 (D.C. Cir. 1984) (en banc); Jones v. United States, 432 A.2d 364, 378-79 (D.C. 1981) (Ferren, J., dissenting), aff d, 463 U.S. 354 (1983); German \& Singer, Punishing the Not Guilty: Hospitalization of Persons Acquitted by Reason of Insanity, 29 RuTGERS L. REv. 1011, 1022-23 (1976); Kirschner, Constitutional Standards for Release of the Civilly Committed and Not Guilty by Reason of Insanity: A Strict Scrutiny Analysis, 20 ARIz. L. REv. 233, 276 (1978).

127 See, e.g., Lynch, 369 U.S. at 715 (implying that criminals could easily establish insanity defense); Warren v. Harvey, 632 F.2d 925, 932 (2d Cir. 1980) (dictum) (warning against "calculated abuse of the insanity defense"); German \& Singer, supra note 426, at 1020-21.

${ }^{128}$ See, e.g., Wexler, Redefining the Insanity Problem, 53 Geo. Wash. L. Rev. 528, 529 (1985) (noting proposals to eliminate insanity defense); Jonakait, Two Proposals for Abolishing the Insanity Defense (Book Review), 35 Hastings L.J. 403 (1983) (reviewing W. Winslade \& J. Ross, The Insanity Plea (1983) and N. Morris, Madness and the Criminal Law (1982)).

128 See, e.g., City of Cleburne v. Cleburne Living Center, 105 S. Gt. 3249, 325558 (1985) (rejecting appellate court ruling that mental retardation is a quasi-suspect classification, but finding zoning ordinance irrational as applied); Schweiker v. Wilson, 450 U.S. 221, 230-31 n.13 (1981) (refusing to reach the issue of what standard of review applies to legislation classifying the mentally ill).

130 See, e.g., Youngberg v. Romeo, 457 U.S. 307, 314-15, 324 (1982) (substantive due process); Addington v. Texas, 441 U.S. 418, 425, 431 (1979) (procedural due process); McNeil v. Director, Patuxent Inst., 407 U.S. 245, 251 (1972) (procedural due process); Jackson v. Indiana, 406 U.S. 715, 733, 738 (1972) (substantive due process).

4si See, e.g., City of Cleburne, 105 S. Ct. at 3258; Jackson, 406 U.S. at 729; Baxstrom v. Herold, 383 U.S. 107, 111 (1966). 
untary commitment. In 1975 the Court held that the state could not commit a mentally ill person merely for custodial purposes without a finding that he was dangerous to himself or others. ${ }^{432}$ Apparently, this was a pure substantive due process holding that vindicated the constitutional right to "liberty" in the sense of freedom from confinement. 433 The Court launched its equal protection campaign in 1966 with Baxstrom $v$. Herold. ${ }^{\mathbf{4 9 4}}$ A prisoner allegedly had become insane during his incarceration, and the state sought to confine him beyond the expiration of his sentence. The Court condemned as irrational the state's refusal to provide him the procedural safeguards available under state law in civil commitment hearings. "For purposes of granting judicial review before a jury of the question whether a person is mentally ill and in need of institutionalization, there is no conceivable basis for distinguishing the commitment of a person who is nearing the end of a penal term from all other civil commitments." ${ }^{435}$ The equal protection rationale in Baxstrom enabled the Court to extend complex procedural protections to allegedly ill persons involved in the criminal justice system without having to grapple with the question of constitutional minimum standards for commitment proceedings. The Court also employed the rationality analysis of Baxstrom in Humphrey $v$. Cady ${ }^{\mathbf{4 3}}$ and Jackson $v$. Indiana. ${ }^{\mathbf{4} 7}$ The Court did, however, find that due process required at least some hearing on the issues underlying the commitment. ${ }^{488}$

In 1979, in Addington v. Texas, ${ }^{439}$ the Supreme Court directly confronted the issue of a minimum constitutional burden of proof in civil commitment proceedings. The Court employed the procedural due process analyses of In re Winship ${ }^{\mathbf{4 4 0}}$ and Mathews v. Eldridge. ${ }^{41} \mathrm{Ex}-$ amining the risk of error, the relative stakes of government and individual, and the enormity of a mistaken commitment, the Court concluded

432 See O'Connor v. Donaldson, 422 U.S. 563, 576 (1975). The Court left open the question of whether a mentally ill person who posed no danger could be confined for the purpose of treating her illness because the plaintiff in this case had received no treatment. See id. at 573-74.

4s3 See id. at 573.

4s. 383 U.S. 107 (1966).

sas Id. at 111-12.

436 405 U.S. 504, 508 (1972) (jury trial; other issues involving presence at hearing and confrontation of witnesses remanded for further exploration).

437406 U.S. 715, 729-30 (1972) (commitment standards and release conditions).

483 See McNeil v. Director, Patuxent Inst., 407 U.S. 245, 251 (1972) (finding that ex parte procedure violates due process.); Specht v. Patterson, 386 U.S. 605, 610 (1967) (finding that where commitment as dangerous sex offender requires resolution of factual issues beyond elements of offense, hearing on those issues is required).

439441 U.S. 418 (1979).

40397 U.S. 358 (1970).

441424 U.S. 319 (1976). 
that the risk should not be allocated equally between the parties, as a preponderance standard would do.42 Rather, due process required proof by clear and convincing evidence that the individual was mentally ill and in need of hospitalization. ${ }^{443}$

Meanwhile, the lower courts had been exploring the implications of equal protection for criminal defendants newly acquitted on grounds of insanity. Shortly after Baxstrom, the D.C. Circuit held in Bolton v. Harris ${ }^{44}$ that existing procedures for commitment of insanity acquittees in the District of Columbia were inadequate. Judge Bazelon emphasized that, under federal law, insanity acquittal indicated nothing more than the existence of a reasonable doubt about the defendant's sanity at the time of the offense, while commitment must be based on a finding of present illness and dangerousness. ${ }^{455}$ Acquittal could be followed by brief confinement for examination, but thereafter the government must provide a "judicial hearing with procedures substantially similar to those in civil commitment proceedings," including proof of insanity and dangerousness by a preponderance of the evidence. ${ }^{446}$ The Supreme Court cited this decision with approval, ${ }^{447}$ but Congress reacted against Bolton, as well as other examples of Judge Bazelon's activism in the insanity field. Emphasizing the interaction of the D.C. Circuit's lenient substantive standard for insanity acquittal with the procedural consequences of Bolton, Congress argued that numerous defendants would avoid both conviction and commitment. ${ }^{488}$ Accordingly, Congress amended the D.C. Code, adopting for both local and federal courts in the District a distinctive procedure that still remains in effect for local crimes. ${ }^{40}$ The statute permits acquittal only when the defendant's insanity has been established by a preponderance of the evidence and predicates commitment on this finding of insanity at the criminal

112 See Addington, 441 U.S. at 425-27.

4s See id. at 432-33. The issue of hospitalization for treatment, left open in O'Connor v. Donaldson, 422 U.S. 563 (1975), did not arise in Addington because the state statute permitted civil commitment only if the individual was dangerous to herself or others. See 441 U.S. at $420-21,426$.

144395 F.2d 642 (D.C. Cir. 1968).

145 See id. at 647-49.

416 See id. at 651 \& n.50. Bolton, of course, preceded the Addington standard of clear and convincing evidence for civil commitment.

147 See Jackson v. Indiana, 406 U.S. 715, 724 (1972).

148 See H. R. REP. No. 907, 91st Cong., 2d Sess. 74 (1970); see also United States v. Jackson, 553 F.2d 109, 115-17 (D.C. Cir. 1976) (quoting the House report).

140 Since 1984 , the federal courts have been governed by the new uniform federal procedure on commitment of insanity acquittees. See infra notes 462-67 and accompanying text. However, this procedure does not govern violators of statutes that apply only in the District. See 18 U.S.C. § 4247(j) (Supp. II 1984). 
trial. ${ }^{450}$

Thereafter, a defendant seeking release from commitment must prove by a preponderance of the evidence that she is no longer insane and dangerous. ${ }^{451}$

Other state and federal courts reached divergent conclusions on the permissible diminution of procedural safeguards for insanity acquittees as compared to civil committees. The recurring issues included both the initial commitment of the acquittee based on nothing more than the verdict on the insanity defense, and the showing she must make to secure release from confinement thereafter. Some courts held that a verdict founded on a reasonable doubt as to sanity justified indefinite commitment with the burden on the acquittee to prove her recovery. ${ }^{\mathbf{1 5 2}}$ Others rejected even an initial commitment without a hearing on present mental state ${ }^{453}$ or required the state to shoulder the burden of demonstrating the need for continued confinement. ${ }^{454}$ The problem became particularly acute after Addington, because most states did not give the acquittee the benefit of the clear and convincing evidence standard. ${ }^{455}$

Some of these issues were eventually resolved in Jones $v$. United States, ${ }^{486}$ in which the Supreme Gourt narrowly upheld the District of Columbia procedure for automatic commitment. ${ }^{457}$ The Court minimized the importance of equal protection principles in the commitment procedure, pointing out that if due process required less for post-acquittal commitment than for civil commitment, then surely there must be a rational basis for providing different procedures. ${ }^{458}$ The Court dis-

450 D.C. Code AnN. § 24-301(j) (1981); cf. United States v. Greene, 489 F.2d 1145, 1153-56 (D.C. Cir. 1973) (upholding change in burden of proof at trial against due process challenge), cert. denied, 419 U.S. 977 (1974).

451 D.C. CODE ANN. § 24-301(k)(3) (1981).

452 See, e.g., People v. Chavez, 629 P.2d 1040 (Colo. 1981); see also Benham v. Edwards, 678 F.2d 511 (5th Cir. 1982) (30 day observation period before commitment not challenged), vacated, 463 U.S. 122 (1983), on remand, 785 F.2d 1480 (11th Cir. 1986).

453 See, e.g., Powell v. Florida, 579 F.2d 324 (5th Cir. 1978).

t54 See, e.g., Benham, 678 F.2d at 525; State v. Clemons, 110 Ariz. 79, 81-83, 515 P.2d 324, 326-28 (1973); State v. Krol, 68 N.J. 236, 257, 344 A.2d 289, 300 (1975).

455 See Benham, 678 F.2d at 521-25; Note, Commitment Following an Insanity Acquittal, 94 HARv. L. REv. 605, 605-06 \& nn.5-6 (1981).

458463 U.S. 354 (1983).

${ }^{457}$ For negative commentary on this result, see $i d$. at 371 (Brennan, J., dissenting); id. at 387 (Stevens, J., dissenting); Marguiles, supra note 423, at 801-03, 810-13; Note, Automatic and Indefinite Commitment of Insanity Acquittees: A Procedural Straitjacket, 37 VAND. L. REV. 1233, 1258-59 (1984).

sss See Jones, 463 U.S. at 362 n.10. 
tinguished the acquittee's position by recognizing that an insanity acquittal in the District necessarily rested on a finding beyond a reasonable doubt that the defendant had committed a crime, and a finding by a preponderance of the evidence that her commission of the crime resulted from mental illness. ${ }^{450}$ The Court held these findings to be a sufficiently reliable predicate for initial commitment of an insanity acquittee. Moreover, the risk allocation analysis of Addington was inapplicable where the defendant herself asserts and proves her insanity and a resulting criminal act. ${ }^{\mathbf{4 0 0}}$ Under these circumstances, it was even appropriate for the defendant to be confined for a period potentially exceeding the maximum sentence she could have received if she had been convicted; release procedures were available should the defendant cease to be insane or dangerous, and Jones had not challenged their adequacy. ${ }^{\mathbf{4} 1}$ Thus, the Court made clear in Jones that a criminal defendant acquitted on insanity grounds can be committed initially for treatment and the protection of society, at least where she has raised the defense of insanity, her criminal act has been proven beyond a reasonable doubt, and its roots in insanity have been demonstrated by a preponderance of the evidence.

Congress took advantage of the Jones holding in passing the Insanity Reform Act of $1984,{ }^{\mathbf{4} 2}$ actually one of a package of criminal law revisions tacked on as a rider to an appropriations bill shortly before the 1984 elections. The statute represents a severe crackdown on the insanity defense in the federal criminal law. It redefines the substance of the defense, eliminating its "volitional" component," all federal defendants to prove their insanity at the time of the offense by clear and convincing evidence. ${ }^{464}$ For the first time, automatic commitment of insanity acquittees is required in all federal courts. ${ }^{485}$ Acquittees later seeking release must demonstrate their lack of dangerousness; the standard of proof depends on the nature of their crimes. ${ }^{486}$

150 See id. at 363-66. The Court rejected the notion, championed by some lower courts, of an unbridgeable gap between insanity at the time of the crime and present insanity. It found that a presumption of continuing insanity comported with common sense and remitted an acquittee asserting changed circumstances to the subsequent release procedures. See id. at 366.

160 See id. at $366-68$.

101 See id. at 368-69. Jones, however, does not directly resolve issues regarding the burden of proof or other procedures at the release hearing. See id. at 363 n.11; Williams v. Wallis, 734 F.2d 1434, 1439 (11th Gir. 1984).

${ }^{402} 18$ U.S.C. $\S 20$ (a) (Supp. II 1984).

163 See id.; S. REP. No. 225, 98th Cong., 1st Sess. 225 (1983), reprinted in 1984 U.S. Code Cong. \& ADmin. News 3182, 3407.

184 U.S.C. § 20(b) (Supp. II 1984).

${ }^{165}$ Id. $\S 4243(\mathrm{a})$.

168 Id. $\S 4243$ (d) (proof by clear and convincing evidence required if offense in- 
Nationwide automatic commitment abolishes for the future the discrimination challenged in Cohen. ${ }^{467}$ The validity of the commitment procedures follows a fortiori from Jones. Whether the highly restrictive release provisions satisfy due process remains an open question.

\section{Analyzing Cohen's Challenge}

The Cohen case reached a D.C. Circuit panel before the Supreme Court's decision in Jones. ${ }^{488}$ It was decided by the court en banc, with an opinion written by then Judge Antonin Scalia, after Jones, ${ }^{469}$ but before the passage of the Insanity Reform Act. The original panel had some doubt as to whether Addington outlawed the District's procedures altogether but avoided this question by focusing on the territorial discrimination among federal defendants. ${ }^{470}$ Of course, Jones settled this question by distinguishing Addington.

Cohen's equal protection attack rests on the distinction between the treatment given to defendants acquitted of federal crimes under the United States Code ${ }^{471}$ in the federal district courts in the states and defendants similarly acquitted in federal district court in the District of Columbia. At that time, once defendants outside the District persuaded the factfinder that there was reasonable doubt as to their sanity, they could be acquitted and released. ${ }^{\mathbf{4 7 2}}$ The federal government would not seek to confine them for treatment or incapacitation. ${ }^{473}$ In fact, federal law did not really permit a verdict identifying the defendant as not guilty by reason of insanity; only a general verdict of not guilty was

volved risk of bodily injury or serious damage to property; otherwise proof by a preponderance of the evidence is required).

168 The new standards control in all federal prosecutions except those for violation of statutes applying only in the District of Columbia. See 18 U.S.C. § 4247(j) (Supp. II 1984).

168 See United States v. Cohen, No. 81-1036, (D.C. Cir. March 5, 1982).

489 See United States v. Gohen, 733 F.2d 128 (D.C. Cir. 1984).

470 See United States v. Cohen, No. 81-1036, slip op. at 2, 7 \& n.7 (D.C. Cir. March 5, 1982).

${ }^{471}$ Codification of a statute in one Code or another is purely formalistic, and should have no effect on the equal protection question. The "U.S. Code" argument Gohen raised, Cohen, 733 F.2d at 132, is a poor proxy for the real problem of distinguishing "local" from exclusively "national" legislation within the district. See supra text accompanying notes 388-418. But see Note, supra note 423, at 294.

${ }^{172}$ See Cohen, 733 F.2d at 131; Tydings, A Federal Verdict of Not Guilty by. Reason of Insanity and a Subsequent Commitment Procedure, 27 MD. L. REv. 131, 131 (1967).

173 State officials sometimes cooperated by bringing civil commitment proceedings against federal acquittees. See Cohen, 733 F.2d at 131; United States v. McCracken, 488 F.2d 406, 416-17 (5th Cir. 1974); United States v. Freeman, 357 F.2d 606, 625-26 (2d Cir. 1966). 
authorized. ${ }^{474}$

In the District, a special verdict of not guilty by reason of insanity occurred after a finding that the defendant was otherwise guilty of the crime, and a finding by a preponderance of the evidence that the crime resulted from insanity. ${ }^{475}$ Thereupon, the court automatically committed the defendant to St. Elizabeth's Hospital, and the burden was then on her to justify her release. ${ }^{476}$ This was a pure location discrimination, because the variation turned on the location of the forum, which, under criminal venue rules, normally depends on the place where the crime was committed. ${ }^{477}$

The strongest response to the equal protection argument is that no fundamental right is implicated in the challenged procedure. The Supreme Court purported to decide the relevant precedents on rationality grounds and has never recognized a fundamental right in the equal protection sense in the commitment area. In fact, the court of appeals en banc reversed the panel on precisely these grounds. ${ }^{48}$ Nonetheless, because the Supreme Court's actions have seemed to contradict its rhetoric in the mental health cases, and because Cohen presents a good context for examining the nature of federal territorial discrimination, let us accept the contention that fundamental rights equal protection would require heightened scrutiny if the discrimination were not geographical.

Automatic commitment of insanity acquittees can be justified in part as an action taken by Congress for the benefit of the District of Columbia. First, because there is only one government in the District, if Congress does not take responsibility for treatment of the mentally ill there, no state will. Second, Congress is similarly responsible for protection of persons in the District from dangerous acts that insanity acquittees may later commit. Other, possibly less legitimate, purposes of commitment have been identified: it may serve covertly to punish those who have escaped the criminal sanction and it may deter excessive use

174 See McCracken, 488 F.2d at 418; 3 C. Wright \& K. Graham, Federal Practice AND Procedure 512 (1982). The 1984 Act now authorizes a special verdict of "not guilty only by reason of insanity." 18 U.S.C. § 4242(b) (Supp. II 1984).

475 See D.C. CoDE ANN. § 24-301(c)(1) (1981); see also United States v. Jones, 463 U.S. 354, 364 (1983); United States v. Brawner, 471 F.2d 969, 1008 (D.C. Cir. 1972) (en banc).

${ }_{476}$ See D.C. Code AnN. § 24-301(d)(2) (1981); Cohen, 733 F.2d at 131.

177 See FED. R. GRIM. P. 18. See generally U.S. ConST. art. III, § 2, cl. 3 ("The trial of all Crimes . . . shall be held in the State where the said Crimes shall have been committed, but when not committed within any State, the Trial shall be at such Place or Places as the Congress may by Law have directed.").

${ }^{178}$ Compare Cohen, 733 F.2d at 133-34, with id. at 150 n.* (Mikva, J., concurring) and United States v. Cohen, No. 81-1036, slip op. at 5-6 (D.C. Cir. Mar. 5, 1982). 
of the insanity defense. ${ }^{479}$ But putting these to one side, Congress certainly has reason for being particularly concerned with the future of insanity acquittees in the District.

These concerns do not necessarily extend to federal insanity acquittees in the states. The treatment and protection rationales do not depend on exclusively federal interests but rather relate to a state's traditional concern for the welfare of its citizens in both the police power and the parens patriae senses. Leaving such decisions to the states well serves the interest in state self-determination on which this Article has focused. ${ }^{480}$

The method suggested earlier for identifying permissible federal discrimination validates the discrimination challenged in Cohen. First, the federal policy presses more heavily on fundamental rights within the District than without. Second, the policy that Congress was pursuing in the District and leaving to the states elsewhere implicates local general welfare powers, not exclusively national powers of Congress. Third, the federal government left the states free to create similar burdens on fundamental rights within their own jurisdiction. Congress did not interfere with state adoption of systems of automatic commitment for defendants acquitted on insanity grounds in state courts. ${ }^{481}$ Nor did it act to preclude the states from committing defendants newly acquitted on insanity grounds in federal court. ${ }^{\mathbf{4 8 2}}$

The last point requires some amplification. Congress did not go as far as it might have in facilitating state policies on commitment. Congress did not adopt state law on commitment of insanity acquittees and make it binding on the federal courts. ${ }^{483}$ Nor did Congress direct the federal courts in the states to make the findings regarding proof of insanity and proof of the criminal act on which automatic commitment

478 See generally Jones v. United States, 432 A.2d 364, 376-81 (D.C. 1981) (Ferren, J., dissenting), affd, 463 U.S. 354 (1983); Note, supra note 455, at 607-17.

${ }^{480}$ Congress expressly recognized the federalism consequences of nationwide automatic commitment and hesitated on those grounds. See H.R. REP. No. 1396, 96th Cong., 2d Sess. 559, 561 (1980), quoted in Cohen, 733 F.2d at 137-38. Congress recently reversed this policy but still urges the state to accept responsibility for the persons committed. See 18 U.S.C. $\S$ 4243(e) (Supp. II 1984). With federal involvement has come federal regulation. See id. at $\S 4243$ (f) (release from state facility to be sought in federal court); $i d$. at $\S 4247$ (i) (standards to be established for facilities).

${ }^{481}$ Indeed, numerous states do have them. See, e.g., Jones v. United States, 463 U.S. 354, 370 n.20 (1983); United States v. Cohen, 733 F.2d 128, 131 n.7 (D.C. Cir. 1984) (citing nine state statutes).

${ }^{182}$ Cohen, 733 F.2d at 131.

483 One might doubt, however, how fully this would further state self-government, or whether the states would prefer to interpret and enforce their own laws in their own tribunals. See, e.g., Pennhurst State School \& Hosp. v. Halderman, 465 U.S. 89, 10306 (1984). 
proceedings in the District were based. ${ }^{484}$ It is possible that the absence of those findings at the criminal trial would prevent the states from committing an insanity acquittee without a further hearing. Nevertheless, these obstacles to precise identity between state and District practice do not implicate equal protection concerns or vitiate the contribution to self-government made by Congress's leaving mental health policy to the states. Congress provides machinery for enforcement of all the laws of the District without similarly supporting enforcement of the laws of the states. ${ }^{485}$ Some degree of duplicative investment in the legal machinery is inherent in the separate existence of the states as contemplated by the Constitution. ${ }^{\mathbf{4 8}}$ This division of labor may sometimes work unnecessarily to the advantage of citizens of the states, in comparison to those in the more unified government system of the District of Columbia. ${ }^{487}$ But the failure of the federal government to involve its personnel in enforcing state law does not eliminate the democratic value served by Congress's self-restraint.

Thus, even if fundamental rights are at stake, the territorial discriminations present in Cohen should be excused from heightened scrutiny and should be upheld if rational. Congress's decision to tailor federal criminal procedure to its mental health policies for the District, while leaving the states to craft their own policies and procedures outside the District, is unquestionably rational.

The opinion of three judges concurring in the judgment of the en banc court in Cohen advocated an analysis somewhat similar to that described here. ${ }^{488}$ Pursuing Judge Wright's argument in United States v. Thompson, ${ }^{489}$ Judge Mikva emphasized the distinction between action taken by Congress "in its capacity as local sovereign" for the Dis-

184 Such findings are being made under the new federal law. See supra text accompanying notes 465-66.

${ }^{485}$ This includes not only the fiscal support of the local police force, but the services of the United States Attorney as prosecutor for the District, and United States District Court jurisdiction over local criminal offenses. See, e.g., Note, supra note 423.

486 See, e.g., Pennhurst, 465 U.S. at 103-06; Tarble's Case, 80 U.S. (13 Wall.) 397, 406-08 (1871).

${ }^{487}$ See, e.g., Swain v. Pressley, 430 U.S. 372 (1977) (habeas corpus proceeding before article III judge unavailable in the District); District of Columbia v. Carter, 409 U.S. 418 (1973) ( $\$ 1983$ action unavailable to District residents); Note, supra note 423 , at $324-25$ \& n.165 (discussing advantages to prosecution resulting from joinder opportunities in the District).

188 See United States v. Cohen, 733 F.2d 128, 141-50 (Mikva, J., joined by Robinson, C.J., and Wright, J.). Judges Mikva and Wright formed the original panel majority that initially accepted Cohen's argument.

${ }^{180}$ See 452 F.2d 1333 (D.C. Cir. 1971) (holding that the postconviction bail provisions of the District of Columbia Court Reform and Criminal Procedure Act of 1970 apply only" to persons convicted of purely "local" offenses). 
trict and action taken by Congress "as a national legislative body." When Congress acts as a local sovereign, and federal law permits the states themselves to do what Congress has done, then equal protection analysis simply has no application. ${ }^{401}$ The difference between the District of Columbia law and federal law in the states should thus be as immune from scrutiny as differences between laws of the states, and for the same reason: because persons in their respective domains are not "similarly situated" with respect to the enacting legislatures. ${ }^{492}$ This rule covered the situation in Cohen, for the concurring judges confronted the issue left open by the majority and concluded that states could adopt procedures for automatic commitment of federal acquittees. ${ }^{493}$ Accordingly, Congress was acting as a state could, and equal protection did not apply. In contrast, where Congress acts as a national legislature, it may only discriminate against the District of Columbia in situations where it could discriminate identically against one of the states. ${ }^{494}$ Incorporation of local law is not discrimination, even though the local rule for the District is also written by Congress. ${ }^{495}$ Where Congress adopts a uniform rule in the states, and a different rule in the District, however, normal equal protection principles do apply. ${ }^{498}$ In fact, equal protection may have slightly more bite than usual here be-

490 See Cohen, 733 F. 2d at 141-42 (Mikva, J., concurring).

401 See id. at 142. It is unclear from the opinion whether "federal law" includes constitutional barriers or only legislative barriers. See id. The opinion's conclusion that state courts could match the federal procedure because automatic commitment would not unduly burden the right to raise an insanity defense in federal court, see id. at 148, suggests that the concurring judges may have had only the preemption argument in mind.

402 See id. at 144.

${ }^{403}$ Compare id. at $142,144,148$ (concurrence) with id. at $131 \mathrm{n} .8$ (majority). Although this is an open question, it has been mooted by the new federal provisions.

104 See id. at 143 (Mikva, J., concurring).

$48 \mathrm{~s}$ See id.

${ }^{496}$ See $i d$. at 144-45. For example, under the analysis of the concurring judges, if Congress made it a federal crime to murder a federal officer and prescribed a stiff term of imprisonment in the states but the death penalty in the District, equal protection principles would apply. See id. My own analysis of this example is that because Congress has apparently left the states free to enact their own statutes imposing the death penalty for murder of federal officers, and because protecting federal officers against murder is not exclusively a national power, the discrimination here should be treated no differently from that in Cohen. That Congress chose to enact a death penalty applicable only in the District of Columbia rather than enacting a separate statute for the District and codifying it in the D.C. Code is a matter of form not substance. If, on the other hand, Congress prohibited the states from applying their murder statutes to the killing of federal officers and then imposed the death penalty for such killings only in the District, a more troubling equal protection issue would arise (although the Supreme Court has never applied heightened scrutiny to the classifications employed in meting out capital punishment). 
cause of the District's unrepresented status. ${ }^{497}$

The Cohen majority brusquely rejected this analysis in a footnote. ${ }^{488}$ Equal protection, then Judge Scalia wrote, does not depend on whether Congress acts in a "local" or a "national" capacity. Congressional preemption of state lawmaking authority would not affect Congress's power to discriminate against the District. Any statute applying only within the District is ipso facto an exercise of Congress's plenary authority to enact local legislation. ${ }^{498}$ Furthermore, the existence of a separate grant of legislative authority over the District demonstrates that enactment of legislation applying only within the District is always rational. ${ }^{500}$

It should come as no surprise that I regard the Cohen concurrence as closer to the mark than the majority. I believe the concurrence errs in suggesting that no equal protection scrutiny applies when Congress acts in its local capacity. ${ }^{501} \mathrm{I}$ also disagree with its method for distinguishing the exceptional national legislation and preemptive action that subjects congressional discrimination to normal equal protection analysis. ${ }^{502}$ Nonetheless, I believe the concurrence emphasizes important factors whose relevance the majority utterly rejects. Congress cannot always discriminate against or in favor of the District of Columbia, ${ }^{\text {Dos }}$ and when it does, the extent to which Congress leaves the states free to mimic its actions is crucial in determining the kind of justification equal protection principles require.

197 See id. at 145-46.

408 See id. at $132-33$ n.10.

400 See id.

soo See id. at 138-39. Judge Scalia also noted that the legislation was rational because it served important federalism interests and because Congress could believe that the District had special needs with regard to crimes committed by the mentally ill. See id. at 137-38. But he regarded the existence of a separate constitutional power addressing the District as being sufficient to sustain the discrimination even without these factors. See id. at 139.

sor See id. at 141-42 (Mikva, J., concurring). I would argue that the rational basis test always applies, though it would be easily satisfied in every instance that the concurrence regards as "local" legislation. I believe the concurrence is wrong to carve up Congress into two distinct conceptual entities, and then to treat the limits equal protection places on Congress-as-local-sovereign as equivalent to those equal protection places on Maryland-as-state-legislature. The States are distinct governments, and the fourteenth amendment treats them as such; the federal government is one government and should be treated accordingly.

${ }^{502}$ See id. The concurrence's "national" category is far broader than the narrow category of action justifiable solely by nationwide powers, and its definition of preemption apparently includes cases where the states are free to equalize the situation. See id.

${ }^{603}$ Although the concurring judges devote most of their attention to discrimination against the District, they appear to treat discrimination favoring the District as comparable to discrimination favoring one of the states. See id. at 142,147. Of course, I agree with this analysis. 


\section{B. The School Finance Cases}

The other example that I would like to discuss concerns intrastate discrimination in educational opportunity resulting from inequalities in school district wealth. The discrimination arises from the fact that states assign local school districts both the responsibility of providing free public education and substantial responsibility for financing this education but give them grossly unequal revenue sources, primarily tied to the local property tax base, from which to meet their responsibilities. ${ }^{504}$ In San Antonio Independent School District v. Rodriguez, ${ }^{503}$ the Supreme Court indicated that such discrimination would be subjected to strict scrutiny if education were a fundamental right for purposes of the equal protection clause but rejected this premise on the grounds that the federal Constitution did not single out education for special protection. ${ }^{506}$ That holding does not deprive the example of all practical interest, however, for three reasons: first, because the Supreme Court has left open the possibility that it may some day recognize access to a minimally adequate public education as a fundamental right; ${ }^{.07}$ second, because the analysis of school finance is instructive for other situations where the differing fiscal capacities of local governments lead to unequal distribution of fundamental rights; and third, because school finance litigation continues at the state constitutional level. Every state constitution contains guarantees respecting education, ${ }^{\mathrm{S} 08}$ and several state supreme courts have concluded that they must travel a road not taken by the United States Supreme Court. ${ }^{\text {.09 }}$

State courts have interpreted a variety of clauses in their constitutions as imposing constraints equivalent to those of the federal equal

sot The literature on this topic is voluminous. See, e.g., J. Coons, W. Clune \& S. Sugarman, Private Wealth and Public Education, (1970) [hereinafter J. Coons]; Developments in the Law-The Interpretation of State Constitutional Rights, 95 HaRv. L. REv. 1324, 1444-59 (1982) [hereinafter Developments in the Law]; Future Directions for School Finance Reform, 38 LAW \& ConTEMP. Probs. 299 (1974); see also Pauley v. Kelly, 255 S.E.2d 859, 893-94 (W. Va. 1979) (listing a bibliography).

sos 411 U.S. 1 (1973).

sos See id. at 16-17.

${ }^{0}$ See Papasan v. Allain, 106 S. Ct. 2932, 2944 (1986).

${ }^{508}$ See Developments in the Law, supra note 504, at 1446.

soo See, e.g., Dupree v. Alma School Dist., 279 Ark. 340, 651 S.W.2d 90 (1984); Serrano v. Priest, 18 Cal. 3d 728, 557 P.2d 929, 135 Cal. Rptr. 345 (1976), cert. denied, 432 U.S. 907 (1977); Horton v. Meskill, 172 Conn. 615, 376 A.2d 359 (1977); Robinson v. Cahill, 62 N.J. 473, 303 A.2d 273, cert. denied, 414 U.S. 976 (1973); Seattle School Dist. v. State, 90 Wash. 2d 476, 585 P.2d 71 (1978); Pauley v. Kelly, 255 S.E.2d 859 (W. Va. 1979); Washakie County School Dist. v. Herschler, 606 P.2d 310 (Wyo.), cert. denied, 449 U.S. 824 (1980). 
protection clause. ${ }^{.10}$ Three states have relied on such clauses as the basis for striking down discriminatory schemes of school finance. ${ }^{511}$ Other states have avoided recourse to a potentially rigid equal protection rationale by invalidating unequal financing schemes directly as violations of state guarantees of education; some of these decisions leave equal protection questions open. ${ }^{512}$ Other states have not yet ruled on the school finance problem. If a state adheres to a constitutional doctrine of equal protection sufficiently similar to the federal doctrine to make the framework outlined in this article relevant, how should it analyze a school finance case?

Not surprisingly, I will argue that the proper approach to school finance cases depends on the nature of the school finance scheme under

s10 See Developments in the Law, supra note 504, at 1472-74, 1481-82; see, e.g., Serrano, 18 Cal. 3d at 763 n.40, 557 P.2d at 949 n.40, 135 Cal. Rptr. at 365 n.40 (CAL. ConST. art. I., \& 7(a): "A person may not be deprived of life, liberty or property without due process of law or denied equal protection of the laws."); Horton, 172 Conn. at 619 n.3, 376 A.2d at 362 n.3 (CoNN. CoNST. art I, $\S$ 1: "[Equality of Rights.] All men when they form a social compact, are equal in rights; . . . no man or set of men are entitled to exclusive public emoluments or privileges from the community."; ConN. CoNST. art. I, § 20: "[Equal Protection. No Segregation or Discrimination.] No person shall be denied the equal protection of the law nor be subjected to segregation or discrimination in the exercise or enjoyment of his civil or political rights because of religion, race, color, ancestry or national origin."); Washakie County School Dist., 606 P.2d at 332 (Wyo. CoNsT. art. I, § 34: "All laws of a general nature shall have [a] uniform operation."). But see Thompson v. Engelking, 96 Idaho 793, 802-04, 537 P.2d 635, 644-45 (1975) (questioning whether strict scrutiny exists under Idaho equal protection clause, IDAHO CoNST. art. 1, § 2: "All political power is inherent in the people. Government is instituted for their equal protection and benefit, and they have the right to alter, reform or abolish the same whenever they may deem it necessary; and no special privileges or immunities shall ever be granted that may not be altered, revoked, or repealed by the legislature.").

si1 See Alma School Dist., 279 Ark. at 340, 651 S.W.2d at 90 (Arkansas); Serrano, 18 Cal. 3d at 728, 557 P.2d at 929, 135 Cal. Rptr. at 345 (California); Washakie County School Dist., 606 P.2d at 332 (Wyoming); see also Board of Educ. v. Nyquist, 83 A.D.2d 217, 239-44, 443 N.Y.S.2d 843, 857-60 (1981) (education not "fundamental" but intermediate equal protection scrutiny applies), rev'd, 57 N.Y.2d 27, 439 N.E.2d 359, 453 N.Y.S.2d 643 (1982) (only rationality test applies); cf. Hartzell v. Connell, 35 Cal. 3d 899, 921-26, 679 P.2d 35, 50-54, 201 Cal. Rptr. 601, 616-20 (1984) (Bird, C.J., concurring) (proposing that equal protection forbids public schools from charging students to participate in extracurricular activities).

New Jersey has taken a more flexible sliding scale approach to equal protection, which does not require categorization as a fundamental right to increase the level of scrutiny applied to educational disparities. See Abbott v. Burke, 100 N.J. 269, 295, 495 A.2d 376, 390 (1985).

s12 See, e.g., Horton, 172 Conn. at 646-51, 376 A.2d at 373-75 (relying on "appropriate legislation" provisions of education clause, CoNN. CoNsT. art. 8, § 1); Robinson, 62 N.J. at 492-501, 303 A.2d at 283-87 (relying on "thorough and efficient system of free public schools" guarantee of N.J. ConST. art. 8, § 4, par. 1); Abbott, 100 N.J. at 269, 495 A.2d at 376 (leaving equal protection issues open); Seattle School Dist., 90 Wash. 2d at 510-18, 585 P.2d at 91-99 (relying on clause declaring "paramount duty of the state to make ample provision for the education of all children," WASH. Const. art. $9, \S 1$ ). 
challenge. At the extremes, some methods of school finance clearly amount to state-imposed discrimination that violates equal protection, while others should be regarded as constitutional because any resulting inequalities are purely the result of democratic choice under an unconstrained system of local self-determination. Intermediate school finance systems, however, bring us onto contested terrain, where resolution of the school finance issue turns on a debate between competing visions of local self-determination.

\section{Easy Cases}

Take first the easiest case: the state does not permit the local school districts to pay for education, except out of direct grants from the state, which are grossly unequal in amount. ${ }^{513}$ This is clearly a local option law imposing unequal constraints on different districts, constraints that are wholly of the state's manufacture. Under the framework outlined above, the discrimination should be subjected to heightened scrutiny if education is a fundamental right.

Suppose instead that a state assigns local school districts primary responsibility for financing public education; that it requires them to raise the necessary funds solely from taxes levied on real property in the district; and that it imposes a ceiling on the local property tax rate, one that makes it impossible for the property-poor districts lawfully to raise as much as the property-wealthy districts spend. Such constraints were not unheard of in the wake of the "tax revolt" of the 1970's, and an often-overlooked but important footnote in the Supreme Court's opinion in Rodriguez left open the possibility that such a system could be held unconstitutionally irrational, even if education were not a fundamental right. ${ }^{514}$ Assuming that public education is a fundamental right at the state constitutional level, a system of this kind should not be excused from heightened scrutiny. It too represents a restricted local option scheme, in which the state has provided the different localities with very different menus of choices for the scope of fundamental rights within their limits. The system does not give reign to local self-determination-the property-poor district is forbidden by state law to exert further taxing effort or to seek any other source of revenue that would enable it to match the educational offerings of the richer district. This

${ }^{513}$ Inequality of resources or expenditures in the school finance literature generally means inequality of amounts calculated on a per pupil basis. Other adjustments sometimes have to be made to reflect local variations with unusual effects on costs. See, e.g., Washakie County School Dist., 606 P.2d at 336.

s14 See 411 U.S. at 50 n.107. 
system is functionally the same as the first and should be subjected to heightened scrutiny.

The case remains easy even if we modify the example further, by assuming that state law also authorizes the district to spend on education any money it receives from some additional but unreliable revenue source, say, bequests to the district from philanthropists (subject to suitable controls on the district's actions to make sure that the bequests are wholly voluntary). The district is thereby given another means for attempting to increase its resources, but no legal authority that guarantees an increase. If, as a factual matter, the amounts that districts can routinely raise by soliciting charitable bequests are insignificant in comparison to their school budgets, then this scheme is not realistically different from the previous ones. Practically speaking, the powers granted to the districts by the local option are not substantially equivalent, and the resulting variations in educational offerings should be regarded as a state-imposed discrimination subject to heightened scrutiny, not an excusable exercise in local self-determination.

\section{Harder Cases}

The usual scenario in school finance litigation is substantially more difficult than the foregoing examples. The state makes available to the local school districts a number of funding sources, among which the local real property tax is quantitatively dominant. There is normally no legal ceiling on the property tax rate that a district can impose; the limitations are practical ones. A property-wealthy district can, with minimal effort, raise amounts that the property-poor districts can match only by abandoning all other municipal services, by taxing themselves at a rate that no electorate will endure, or by doing both. ${ }^{615} \mathrm{But}$, in principle at least, the option of catching up with the spending levels of the property-wealthy district is neither illegal nor impossible for the poorer district. Is this then a local option scheme that should be excused from heightened scrutiny?

One partial response may be to focus on the artificiality of limiting educational resources to the proceeds of a property tax. There is no natural law principle that public education must be financed primarily

s1s See, e.g., Serrano v. Priest, 18 Cal. 3d 728, 769, 557 P.2d 929, 953, 135 Cal. Rptr. 345, 369 (1976), cert. denied, 432 U.S. 907 (1977). It must be recognized that comparing tax efforts is an empirically and conceptually difficult undertaking, due both to issues of "municipal overburden," see id. at 757-60, 557 P.2d at 945-47, $135 \mathrm{Cal}$. Rptr. at 361-63, and to the controverted degree to which property tax rates are capitalized into land values. See, e.g., Gurwitz, The Capitalization of School Finance Reform, 5 J. Educ. Fin. 297 (1980); Inman \& Rubinfeld, supra note 201, at 1733-35. 
from a tax levied on real property. Generally the state withholds from the poorer district other taxing methods, including levying excises or personal or corporate income taxes within its boundaries. If a district with a relatively poor property tax base has a relatively rich base for some other taxing method, and if granting the district the authority to levy such a tax would enable it to match the expenditures of propertywealthy districts without unreasonable effort, then once more the decisions the state has made in drafting its local option scheme are responsible for the substantially inequivalent choices made available under that scheme to the various districts. ${ }^{516}$ The state itself has handicapped, for example, the property-poor-but-income-rich district, and unequal opportunities for the exercise of the right to education will flow inevitably from the state's restriction. Before laying too much stress on this discrimination, however, I should acknowledge the limited application of the example: all too often, the tax bases of some property-poor districts would be inadequate under any wealth measure. ${ }^{\text {.17 }}$

Rather than dwell on this partial response, therefore, I want to confront directly the hardest example. Assume that the districts are either rich or poor by any wealth measure, and that so long as their taxing jurisdiction is limited to their physical boundaries, no taxing method will enable districts imposing reasonable tax rates on their low tax bases to catch up with the spending of the wealthier districts. The state may point to the absence of legal constraint on the poorer district's tax rate and argue that the decision not to impose an "unreasonable" tax rate is purely a matter of local choice. But the challengers will then point to a different legal constraint: state law unequally constrains the districts in their choices because it limits their taxing authority to a local tax base. The extreme inequality of sacrifice required for a poor district to catch up with a rich district still results from the state's definition of their taxing powers. "The quality of public education may not be a function of wealth other than the total wealth of the state."'s18

s16 See, e.g., Rodriguez, 411 U.S. at 25-27 (discussing weakness of correlation between district wealth and family wealth); Serrano, $18 \mathrm{Cal}$. $3 \mathrm{~d}$ at 793-96, 557 P.2d at 969-70, 135 Cal. Rptr. at 385-86 (Clark, J., dissenting); Washakie County School Dist. v. Herschler, 606 P.2d 310, 319 (Wyo.), cert. denied, 449 U.S. 824 (1980); of. Comment, A Statistical Analysis of the School Finance Decisions: On Winning Battles and Losing Wars, 81 YALE L.J. 1303, 1323-28 (1972) (showing that, in Connecticut, poor families tend to live in property-wealthy districts).

817 See, e.g., Rodriguez, 411 U.S. at 26-27 ("TT) we wealthiest few districts in the sample have the highest median family incomes and spend the most on education, [and] the several poorest districts have the lowest family incomes and devote the least amount of money to education.").

${ }^{818} \mathrm{~J}$. Coons, supra note 504, at 304. 
The state will reply that limitation to a local tax base is different from limitation to a property tax. Communities' decisions under any local option law regarding fundamental rights will depend on their estimates of the local trade-offs between promoting exercise of the right and achieving countervailing government interests. The urgency of those countervailing interests is likely to vary from community to community. For example, the traffic congestion of an overcrowded city may dictate a more restrictive policy on parades than a rural setting; the greater proportion of children in a suburb may intensify the need for controlling the dissemination of sexually explicit materials. The essence of municipal self-government lies in a local institution's weighing local costs against local benefits. Limiting the districts' taxing jurisdiction to their physical boundaries is part of the process of making the local option an exercise in self-determination. Only in this way will the tax burdens of each district be determined by the district's own choices.

The challenge and the state's defense are based on competing visions of the nature of local self-determination. The challenge contends that the unequal resources of the districts must be viewed as consequences of state allocations, positive state actions. The resulting inequalities in the districts' capacities for affording fundamental rights are similarly attributable to the state and vitiate the claim that the state has simply left the level of educational opportunities to local option. The state's reply treats the fiscal capacities of the districts as natural endowments, and the ability to determine one's local tax burden as an inseparable part of self-determination. Under this view, to say that a local government cannot afford a choice is simply to say that local conditions render the choice unwise in the opinion of the local electorate.

Resolving this debate thus requires a greater refinement of the operative concept of self-determination than we have heretofore found necessary. In a sense, this is the core of the school finance debate-whether local governments should be viewed as autonomous individuals, endowed by "natural" geological, sociological, and economic forces with resource pools from which they can sustain themselves, or whether they should be viewed as interdependent members of a larger state community, who have been allocated certain resources by law but have no inherent claim on those resources immune from their neighbors' call for redistribution. This is a replay of the debate on the public/private distinction in the field of - private property, ${ }^{519}$ except that here the defenders of the status quo are attempting to blur the public/

s19 See, e.g., Brest, State Action and Liberal Theory: A Casenote on Flagg Brothers v. Brooks, 130 U. PA. L. REv. 1296 (1982); Kennedy, The Structure of Blackstone's Commentaries, 28 Buffalo L. REv. 205, 348-49 (1979). 
private line and give the school district the role of the private individual.

Both visions of local self-determination have their proponents, ${ }^{\mathbf{5 2 0}}$ and my purpose here is more to show that this conflict is the key issue in equal protection analysis of this class of school finance cases, than to persuade the reader of the correctness of my own choice between them. But briefly, I would argue that the state should not be able to escape responsibility for its unequal fiscal endowment of its municipalities. The attempt to maintain some form of the public/private distinction is deeply embedded in our constitutional law, and public school districts are an unlikely candidate for privatization. ${ }^{.21}$ None of our constitutions, state or federal, views a state as a confederation of autonomous municipalities. The grant of some extraterritorial taxing authority to local governments is hardly a novelty ${ }^{\mathbf{6 2 2}}$ In most states, the state role in educational policy and school finance is already substantial. ${ }^{\mathbf{2 2}}$ It may also be worth observing that the Supreme Court majority in Rodriguez upheld the Texas finance scheme on the grounds that local fiscal control was rationally related to fostering local autonomy in setting educational policy, not fiscal policy, and that it indicated that the scheme was not necessary to achieving any compelling government interest. ${ }^{824}$ Even the majority was not prepared to accept as a given that local autonomy may be restricted to use of local resources.

520 Compare Serrano, 18 Cal. 3d at 772-73, 557 P.2d at 955-56, 135 Cal. Rptr. at 371-72 and J. Coons, supra note 504, at 14-23 with Buse v. Smith, 74 Wis. 2d $550,571-72,247$ N.W.2d 141, 151 (1976) (invalidating negative aid program to protect right of wealthier districts to tax and spend) and East Jackson Pub. Schools v. Michigan, 133 Mich. App. 132, 140 n.12, 348 N.W.2d 303, 307 n.12 (1984) (stating that the petition to intervene of individual taxpayers and students to protect "the right to determine their own educational financing through self-taxation" should have been granted) and Vieira, Unequal Educational Expenditures: Some Minority Views on Serrano v. Priest, 37 Mo. L. Rev. 617, 629 (1972) (stating that wealthy districts are entitled to spend more because they raise more).

621 See, e.g., Plyler v. Doe, 457 U.S. 202 (1982) (equal protection forbids denial of public education to undocumented alien children); Ambach v. Norwick, 441 U.S. 68, 76 n.6, 78 n.8 (1979) (equal protection permits state to deny resident aliens employment as teachers in public, as opposed to private, schools, because such teachers act as agents of the state). Compare Rendall-Baker v. Kohn, 457 U.S. 830 (1982) (procedural due process not required in firing of employee by privately operated school under government contract) with Cleveland Bd. of Educ. v. Loudermill, 470 U.S. 532 (1985) (procedural due process required in firing of employee by public school).

${ }^{622}$ See, e.g., R. Maddox, Extraterritoriai, Powers of Municipalities in The United States 74-79 (1955); 16 E. MCQuillen, The Law of Municipal Corporations $\S 44.91$ (3d ed. 1984); Anderson, Extraterritorial Powers of Cities, 10 MinN. L. REv. 564, 569-72 (1926).

${ }^{828}$ See, e.g., Rodriguez, 411 U.S. at 45-48; id. at 126-27 (Marshall, J., dissenting); S. Goldstein, Law and Public Education 63-65 (1974); E. ReutTeR \& R. Hamilton, Law of Public Education 109-12 (1970).

s24 See Rodriguez, 411 U.S. at 49-55 \& nn.108 \& 109. 
If this answer is accepted, then school finance schemes that rely heavily on local tax bases should not be excused from heightened scrutiny in those states where education is a fundamental right. As in the easier cases, the school finance scheme is a defective local option law that unequally constrains the respective districts. It must be recognized that this argument is quite general and would apply to more than just education. If there is a fundamental right in the equal protection sense to receive some government benefit or service, then to the extent that substantial inequalities going to the essence of the right would result from unequal constraints on the revenue-raising abilities of different local government units, the same conclusion follows. The state cannot assign operational and fiscal responsibility to local units without giving them comparably adequate revenue sources. This reasoning should potentially be applicable to constitutionalized welfare rights and rights to legal counsel as well as to education. The remedial implications of this argument may daunt a court that is contemplating recognition of a right to government services as a fundamental right for equal protection purposes, but this is what such recognition should entail.

\section{The Other Extreme-District Power Equalization}

The state's interest in local autonomy reenters the case in a different fashion, however, once the state has been directed to eliminate funding inequalities traceable to its allocation of revenue sources. Is it sufficient for the state to equalize the revenue sources of the local units or is the state also obliged to make certain that the local units avail themselves equally of the resources? ${ }^{205}$

One means of reconciling wealth neutrality with local autonomy is the technique known as district power equalization. In this system, the state breaks the link between the wealth of the district and the educational opportunity of its children by ensuring that all districts exerting equal tax efforts can raise equal amounts for education-part of the revenue comes from the local tax base, and the state makes up the difference between what the district has actually raised and what a richer district exerting equal effort would raise. ${ }^{\mathbf{6 2}}$ This method, expounded by Professors Coons, Clune, and Sugarman in their influential book

825 State constitutions may, of course, guarantee local districts the right to determine their own taxing or spending levels. This is a distinct issue from the constitutionality of a state assigning local districts disparate revenue sources.

${ }_{828}$ See, e.g., Serrano v. Priest, $18 \mathrm{Cal}$. 3d 728, 747, 557 P.2d 929, 939, $135 \mathrm{Cal}$. Rptr. 345, 355 (1976), cert. denied, 414 U.S. 907 (1977); J. CooNs, supra note 504, at 200-44. 
Private Wealth and Public Education, ${ }^{527}$ is predicated on the idea that breaking that link resolves the equal protection dilemma. The courts of California, Wyoming, and Connecticut have based their reforms on that idea, though without committing themselves to district power equalization as the remedy. ${ }^{528}$

If, as we have been assuming, state constitutional law subsumes the state and its political subdivisions in a single guarantee of equal protection, then the decisions of different districts to exert different levels of taxing effort combine to form a discrimination imposed on their school children by the state government. Nonetheless, these decisions are independently arrived at by the democratically elected governments of the local districts faced with equal resource pools, not constrained inequalities resulting from discriminatory actions of the central state government. Under both views of self-determination described above, selections made from among options equally available to all districts at equal effort constitute genuine self-determination. Accordingly, if the state equal protection doctrine treats the independent actions of municipalities the way that federal equal protection does, then the decisions of different school districts to provide different degrees of educational opportunity for the children of their respective electorates will be excused from heightened scrutiny. Thus the framework advocated here would be consistent with local autonomy in setting educational policy.

This resolution of the potential attack on district power equalization differs in route, though not in result, from an explanation that may be implicit in the literature and in the cases. If district power equalization is a less restrictive alternative for achieving a state's compelling interest in district autonomy, then district power equalization may also be deemed necessary to achieve that compelling interest and therefore be found to be constitutional. ${ }^{\text {s29 }}$ But how compelling is the state's interest really? District autonomy is not a consistently pursued objective; states typically regulate substantial aspects of educational policy on a

$527 \mathrm{~J}$. Coons, supra note 504.

s28 See Serrano, 18 Cal. 3d at 746-48, 557 P.2d at 983-89, 135 Cal. Rptr. at 35455 (identifying fiscally neutral alternatives); Washakie County School Dist. v. Herschler, 606 P.2d 310, 332 (Wyo.) (requiring only fiscal neutrality), cert. denied, 449 U.S. 824 (1980); Horton v. Meskill, 172 Conn. 615, 652, 376 A.2d 359, 376 (1977) (recognizing compatibility of local control with state's responsibility to "equalize the ability of various towns to finance education").

${ }^{320}$ See, e.g., Serrano, $18 \mathrm{Cal}$. 3d at 768, 557 P.2d at 953, $135 \mathrm{Cal}$. Rptr. at 369 (state interest in local control illusory so long as dependence on property tax base limits control for poorer districts); J. CooNs, supra note 504, at 431-32 (apparently assuming constitutionality of either district power equalization or "family power equalization," i.e., letting each family set its own effort level and equalizing the resources available to families at each level); id. at 203 (apparently defending district power equalization). 
statewide basis. ${ }^{830}$ Thus, the state's education laws, including the feature of district power equalization, are unlikely to be "precisely tailored" to achieving autonomy. ${ }^{\mathbf{5 3 1}}$ Furthermore, district autonomy in setting effort levels cannot be justified as maximizing parents' freedom of choice in determining the level of education for their children. Rather, it sacrifices a child's educational aspirations to the fiscal preferences of a majority in her community. ${ }^{532}$ Nor does district autonomy in setting effort levels serve the state interest in a well-educated child that led to the adoption of statewide compulsory education laws in the first place. A district's freedom to exert a degree of effort unusually low within the state serves only the tautologous interest in collective decisionmaking at the particular geographical level chosen by the state. A district's decision to deemphasize education will normally result from the desire of a majority of its taxpayers to keep for themselves the money that a better education would require, or to have the local government spend it on other projects not involving fundamental rights. Is the state's interest in fiscal policymaking by the community compelling enough to override the equal protection rights of the children ${ }^{\text {s33 }}$ We would not say, for example, that the state has an interest in collective fiscal decisionmaking at the local level compelling enough to justify a county in saving funds for other purposes by denying a free transcript to its indigent criminal defendants. ${ }^{634}$ As I have argued persistently in this Article, the mere effectuation of the majority will is not itself a compelling interest. Rather, the defense of district power equalization is not an application of strict scrutiny but an exception to strict scrutiny. Local autonomy, in

s30 For example, state statutes often prescribe what courses will be offered in public schools. See S. GoldsteIN, supra note 523, at 63.

${ }^{331}$ Moreover, states sometimes permit some students to attend school in districts other than their own, at the expense of their home district, because of particularly suitable educational opportunities available in the host district. See, e.g., MAss ANN. LAws ch. 76, $\S 12$ (Law Co-op 1978). This further qualifies the states' claim that a child's educational opportunity must be defined by the political choices of her own district.

ss2 See Michelman, Foreword: On Protecting the Poor Through the Fourteenth Amendment, 83 HARV. L. REv. 7, 50-54 (1969). Coons, Glune, and Sugarman appeared to regard community control as constitutionally permissible in $\mathrm{J}$. Coons, supra note 504, at 203, but Coons and Sugarman condemn it as unjust in later writings. See, e.g., Coons and Sugarman, Family Choice in Education: A Model State System for Vouchers, 59 Calif. L. REv. 321, 339 (1971).

ss3 The problem may appear especially troublesome when the minority consists of poor parents dependent on the public schools, and the majority consists of wealthy parents who send their children to private school and childless adults. Citizens who have no children, or no desire to send the children they do have to public schools, cannot be excluded from school district elections. See Kramer v. Union Free School Dist., 395 U.S. 621 (1969).

Bs4 See Griffin v. Illinois, 351 U.S. 12, 19 (1956). 
the sense of tolerance for the independent actions of self-governing political subdivisions, survives equal protection review only if it is built into the structure of the analysis.

I believe that recognizing the exceptional nature of the local selfgovernment defense in geographical equal protection cases makes possible a coherent account of the role of "local autonomy" in school finance litigation. An equal protection analysis must grapple with the questions: "Why is the state responsible for saddling a poor child with a low property tax base, but not for saddling her with a community indifferent to her needs?" and "Why does 'local autonomy' justify interdistrict inequalities but not interracial inequalities?" Manipulation of the balance in applying the compelling interest test provides a rhetorical means for announcing a result once it has been reached but gives no guidance for resolving these and related cases. I hope that identifying the preference for local self-determination as an historically grounded exception will help place proper limits on the child's misfortune. ${ }^{\text {s35 }}$

\section{CONCLUSION}

I have tried to argue in this Article that injustices should not be overlooked merely because the injured class is geographically defined. Courts have traditionally been uncomfortable with claims of territorial discrimination, rightly perceiving that territorial classifications are not inherently suspect and that some tolerance of territorial discrimination, even with regard to fundamental rights, is necessary for local government to continue. But the recurring instinct to ban geography from the scope of equal protection is too blunt a response. Provincial rivalries, between North and South, between town and country, between upstate and downstate, illustrate the need to shield fundamental rights against selective disrespect, even from place to place.

The absence of a self-conscious approach to these problems has left the courts to resolve individual cases without a consistent backdrop. This puts equal protection values at risk. By isolating the interest in local self-determination as the key to analysis of geographical discriminations, it should be possible to preserve equality without imposing a rigid uniformity.

s85 Even disparities resulting from autonomous local decisions pursuant to a district power equalization scheme may violate state constitutional provisions that put responsibility directly on the state's central government to ensure the adequacy and thoroughness of public education. See, e.g., cases cited supra note 510. It is unclear whether this can be regarded as an equal protection issue, or whether it is purely a matter for resolution under direct substantive review. Cf. supra note 329. 